\title{
Teorias e práticas em tecnologias educacionais
}

\author{
Robson Pequeno de Sousa \\ Carolina Cavalcanti Bezerra \\ Eliane de Moura Silva \\ Filomema Maria Gonçalves da Silva Moita \\ (orgs.)
}

SOUSA, RP., et al., orgs. Teorias e práticas em tecnologias educacionais [online]. Campina Grande: EDUEPB, 2016, 228 p. ISBN 978-85-7879-326-5. Available from SciELO Books

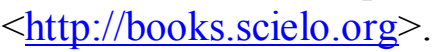

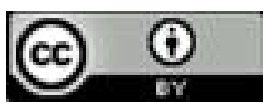

All the contents of this work, except where otherwise noted, is licensed under a Creative Commons Attribution $\underline{4.0 \text { International license. }}$

Todo o conteúdo deste trabalho, exceto quando houver ressalva, é publicado sob a licença Creative Commons Atribição 4.0.

Todo el contenido de esta obra, excepto donde se indique lo contrario, está bajo licencia de la licencia Creative Commons Reconocimento 4.0. 
TEORIAS E PRÁTICAS EM TECNOLOGIAS EDUCACIONAIS 
$\bigcup_{U E P B}$

\&eduepb
Universidade Estadual da Paraíba

Prof. Antonio Guedes Rangel Junior $\quad$ Reitor

Prof. José Etham de Lucena Barbosa | Vice-Reitor

Editora da Universidade Estadual da Paraíba

Luciano do Nascimento Silva | Diretor

Antonio Roberto Faustino da Costa | Diretor-Adjunto

Conselho Editorial

Presidente

Luciano do Nascimento Silva

\section{Conselho Científico}

Alberto Soares Melo

Cidoval Morais de Sousa

Hermes Magalhães Tavares

José Esteban Castro

José Etham de Lucena Barbosa

José Tavares de Sousa

Marcionila Fernandes

Olival Freire Jr

Roberto Mauro Cortez Motta

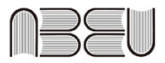

Editora filiada a ABEU

EDITORA DA UNIVERSIDADE ESTADUAL DA PARAÍBA

Rua Baraúnas, 351 - Bairro Universitário - Campina Grande-PB - CEP 58429-500

Fone/Fax: (83) 3315-3381 - http://eduepb.uepb.edu.br - email: eduepb@uepb.edu.br 


\author{
Robson Pequeno de Sousa \\ Carolina Cavalcanti Bezerra \\ Eliane de Moura Silva
}

Filomema Maria Gonçalves da Silva Moita

(Organizadores)

\title{
TEORIAS E PRÁTICAS EM TECNOLOGIAS EDUCACIONAIS
}

\section{\$eduepb}

Campina Grande | PB

2016 
Editora da Universidade Estadual da Paraíba

Luciano do Nascimento Silva | Diretor

Antonio Roberto Faustino da Costa |Diretor-Adjunto

Design Gráfico

Erick Ferreira Cabral

Jefferson Ricardo Lima Araujo Nunes

Lediana Costa Frutuoso

Leonardo Ramos Araujo

Divulgação

Zoraide Barbosa de Oliveira Pereira

\section{Revisão Linguística}

Elizete Amaral de Medeiros

Normalização Técnica

Jane Pompilo dos Santos

\section{Copyright (C) Eduepb}

A reprodução não-autorizada desta publicação, por qualquer meio, seja total ou parcial, constitui violação da Lei n 9.610/98.

Depósito legal na Biblioteca Nacional, conforme Lei n 10.994 , de 14 de dezembro de 2004

\section{FICHA CATALOGRÁFICA ELABORADA PELA BIBLIOTECA CENTRAL - UEPB}

370

T314 Teorias e práticas em tecnologias educacionais./Robson Pequeno de Sousa; Carolina Cavalcanti Bezerra; Eliane de Moura Silva, et al. (Organizadores). - Campina Grande: Eduepb, 2016.

$$
227 p \text {. }
$$

ISBN 978-85-7879-299-2

ISBN EBOOK 978-85-7879-300-5

1. Educação. 2. Recursos eletrônicos. 3. Tecnologias digitais. 4 Tecnologias educacionais. 5.Educação online. I. SOUSA, Robson Pequeno de. II. BEZERRA, Carolina Cavalcanti. III. SILVA, Eliane de Moura Título.

\section{EDITORA DA UNIVERSIDADE ESTADUAL DA PARAÍBA}

Rua Baraúnas, 351 - Bodocongó - Bairro Universitário Campina Grande-PB - CEP 58429-500

Fone/Fax: (83) 3315-3381 - http://eduepb.uepb.edu.br e-mail: eduepb@uepb.edu.br 


\section{SUMÁRIO}

FORMAÇÃO CONTINUADA E AS NOVAS TECNOLOGIAS DA INFORMAÇÃO E COMUNICAÇÃO $\ldots \ldots \ldots \ldots \ldots .7$

ALGUMAS CONSIDERAÇÕES SOBRE A FORMAÇÃO CONTINUADA DE PROFESSORES A PARTIR DAS NECESSIDADES FORMATIVAS EM NOVAS TECNOLOGIAS NA EDUCAÇÃO

Laércia Maria Bertulino de Medeiros Carolina Cavalcanti Bezerra......................17

FORMAÇÃO PARA A DOCÊNCIA NA EDUCAÇÃO ONLINE Taíses Araújo da Silva Alves Robson Pequeno de Sousa.........................39

REDES SOCIAIS NO PROCESSO DE ENSINO E APRENDIZAGEM: COM A PALAVRA O ADOLESCENTE Francineide Sales da Silva Maria Lúcia Serafim............................67

AS GERAÇÕES DE INFOGRÁFICOS COMUNICATIVOS: PROPOSTAS E POSSIBILIDADES PARA A EDUCAÇÃO A DISTÂNCIA Carolina Cavalcanti Bezerra Maria Lúcia Serafim.............................99 
OBJETO DE APRENDIZAGEM EMPREGADO COMO RECURSO MULTIMIIDIA NA MICROBIOLOGIA

Karlete Vania Mendes Vieira

Robson Pequeno de Sousa.......................123

O USO DO LABORATÓRIO DE INFORMÁTICA

EDUCACIONAL: PARTILHANDO VIVÊNCIAS DO

COTIDIANO ESCOLAR

Luzivone Lopes Gomes

Filomena $M^{\underline{a}}$ Gonçalves da Silva Cordeiro Moita. ........151

PROTOTIPAGEM DE UM QUADRO INTERATIVO

UTILIZANDO TÉCNICAS HAND TRACKING PARA

AMBIENTES DE REALIDADE AUMENTADA

Rodrigo Lins Rodrigues

Filomena M. G. da Silva C. Moita ....................175

FORMAÇÃO CONTINUADA E CONECTIVISMO: UM

ESTUDO DE CASO REFERENTE ÀS TRANSFORMAÇÕES DA PRÁTICA PEDAGÓGICA NO DISCURSO DO PROFESSOR Maria Gracielly Lacerda de Abrantes

Robson Pequeno de Sousa........................195

SOBRE OS ORGANIZADORES $\ldots \ldots \ldots \ldots \ldots \ldots \ldots . .223$ 


\section{FORMAÇÃO CONTINUADA E AS NOVAS TECNOLOGIAS DA INFORMAÇÃO E COMUNICAÇÃO}

Precisamos olhar o mundo de hoje com os olhos do mundo de amanhã, não com os do mundo de ontem. Ora, os olhos de amanhã, são os olhos planetários. As fronteiras são as ruínas, ainda de pé, de um mundo em revolução.

(Pierre Lévy)

A Lei de Diretrizes e Bases da Educação Nacional No 9.394/96 regulamentou a Modalidade de Educação a Distância no Brasil. Nos seus artigos 80 e 87, parágrafo $3^{\circ}$, item III legislando sobre a importância da Educação a Distância em programas de Capacitação para Professores em Exercício, assegurando por meio da lei "que o poder público incentivará o desenvolvimento e a veiculação de educação continuada"(LDB, 1999).

A partir de então, teve início, no país, uma mobilização do poder público federal envolvendo as universidades e os poderes estadual e municipal em torno da implementação e expansão da oferta de cursos de formação inicial e continuada direcionada a professores na modalidade a distância. Esse movimento pôs no centro do debate a necessidade de uma nova forma de enxergar a educação brasileira, com reflexos imediatos na formação do professor e no sistema edu- 
cacional em todas as modalidades, exigindo uma reflexão crítica do fazer pedagógico das instituições de ensino superior.

Essa política de formação interferiu imediatamente no pensar de um novo perfil do professor formador e do professor em formação, exigindo desses profissionais uma (re) significação de suas práticas em consonância com os novos paradigmas educacionais que requer de todos os envolvidos estudos e pesquisas no que se refere à construção do conhecimento docente. Portanto, é imperioso que a formação de professores como estratégia política privilegiada para a expansão do curso superior no que se refere à oferta e à mudança de mentalidade acadêmica aconteça não só num momento inicial da carreira, como se pensava anteriormente, mas acima de tudo, durante a trajetória profissional e pessoal do professor. A ideia posta é a de que a formação de professores tanto na formação inicial quanto na formação continuada os prepare com habilidades, competências e capacidades diferenciadas como fator determinante e indissociável da atual revolução tecnológica denominada por Castells (1999) de sociedade da Informação e do Conhecimento.

O desafio reside na constatação de que a Universidade, entendida aqui como Instituição responsável pela formação de profissionais terá que dar respostas às contradições que esta apresenta e as expectativas que se esperam dela. Se por um lado, existem grupos de estudos e pesquisa preocupados sobre como formar professores para a sociedade em curso, por outro, existem professores que resistem a continuar com o mesmo fazer pedagógico que vivenciaram da geração do papel, do lápis e do giz acreditando que a escola não precisa mudar os seus métodos, nem as suas metodologias. Ora, se a geração de hoje é bem diferente da geração do passado em suas formas de agir, de vestir, 
de falar, e de seus estilos de vida, obviamente essa geração não tem o mesmo perfil e comportamentos culturais das gerações passadas.

Para este fenômeno, Piscitelli (2009) corrobora ao definir como os "nativos"a geração de hoje nascida em meio a informação tecnológica, ao computador, aos vídeos games, celulares e internet e os “imigrantes"digitais, para ele, são os que não nasceram nessa era, mas são fascinados por esse universo das inovações e as adotam em seus estilos de vida. Mas afinal imigrantes não são nativos e vive-versa, o que faz a diferença dessa geração com as gerações passadas?

Sobre esta constatação afirma ainda Piscitelli:

Nos encontramos ante uma paradoxal situação: os professores, que são preponderantemente imigrantes digitais, e que não falam uma língua, em vias de extinção, da era pré-digital, estão tentando ensinar a uma população que fala uma linguagem totalmente diferente e que é incompreensível para esses professores imigrantes. Embora o problema quase não seja lido desse modo, grande parte da resistência infanto-juvenil ao ensino hoje hegemônico nas universidades é produto da rejeição dos nativos àqueles que pretendem lhes ensinar a própria linguagem, sendo que eles, os nativos, já falam essa língua arcaica, pois a aprenderam como segunda língua. Um absurdo fadado ao fracasso de antemão. Fica mais claro então o porquê da universidade no lugar arrasado dessa equação? (PISCITELLI, 2009, p.47).

Sem negar essas adversidades, que cobrem essa área de conhecimento os estudos e pesquisas têm demonstrado o quanto tem avançado no país propostas e projetos exitosos de formação de professores utilizando a Educação a Distância como um novo paradigma, para superar o modelo tradicional positivista da educação. De fato, essa modalidade tem tido um papel importante na perspectiva 
de mudança do processo educativo porque possibilita uma inequívoca interação entre formadores e os sujeitos em formação fazendo com que o processo de ensino-aprendizagem se dê numa relação de parceria e de construção coletiva.

Neste contexto, temos o prazer de entregar aos nossos leitores um segundo livro da leva desses Novos Tempos de pensar a Educação brasileira como contributo do papel que a Educação a Distância tem assumido na busca da democratização do ensino superior e na possibilidade de minimizar os desafios da formação de professores da educação básica do Estado da Paraíba.

Desta feita, trata-se de uma coletânea resultante da produção acadêmica dos alunos (professores da educação básica) e professores da UEPB que orientaram e mediaram as ações pedagógicas desenvolvidas pela $3^{\mathrm{a}}$ turma do Curso de Especialização em Novas Tecnologias na Educação, coordenado pelo professor Dr. Robson Pequeno de Souza.

Este curso, o quarto do gênero oferecido pela UEPB, vem firmando-se enquanto ação acadêmica de formação continuada em dois eixos: o primeiro é o de que a Educação a Distância pode ser vista como uma estratégia política de expansão das ações da Universidade. $\mathrm{O}$ segundo, consequência do primeiro, é que a $\mathrm{EaD}$, no tocante à formação de professores, pode ser um espaço privilegiado de acessibilidade desses profissionais que atuam nas redes municipal e estadual de ensino.

Assim, os professores que estudam e pesquisam na área da educação, na UEPB, têm focado as ações acadêmicas de formação, tanto inicial quanto continuada na direção da educação on-line, com foco na prática e na produção do conhecimento, construídos a par- 
tir das vivências de professores da UEPB e de professores do Ensino Médio do Estado da Paraíba.

Os textos aqui expostos, enfileirados sem hierarquização nos remetem a pensar que é possível traçar um novo paradigma para a educação que possibilite aos docentes, em suas práticas em sala de aula, rever suas competências e habilidades para lidar com as Tecnologias da Informação e Comunicação como suportes didático-pedagógicos para ensinar e aprender, de forma virtual, atitudes hoje indispensáveis ao "Ser"professor.

O primeiro texto das autoras Laércia Maria B. de Medeiros e Carolina Cavalcanti Bezerra reflete teoricamente a discussão sobre formação continuada de professores, no Brasil, pautando-se no percurso histórico, social e epistemológico marcado por variadas concepções no âmbito da educação. Nesse sentido, a partir desse referencial teórico, as autoras encontram categorizações temáticas fundamentadas em produções científicas monográficas do curso de Especialização em Tecnologias na Educação, objetivando identificar o que se explicita como temáticas de relevância, além de verificar as demandas e mobilizações de saberes que se articulam com as tecnologias na educação. Fazem ainda algumas reflexões a respeito da necessidade formativa do professor como ponto de partida e de chegada, resultando no entendimento que a unidade teoria e prática são práxis.

O segundo texto de Taíses Araújo da Silva Alves e Robson Pequeno de Sousa trata da disseminação do acesso às Tecnologias Digitais de Informação e Comunicação (TDIC) e a ampliação da oferta de programas de $\mathrm{EaD}$ que trouxe novos desafios para essa modalidade de ensino. Configuram-se novos contextos de ensino e aprendizagem, que provocam transformações no fazer docente e impulsionam mudanças na formação de professores produzidas mediante o adven- 
to da Educação Online. Trata-se de uma Pesquisa Qualitativa de caráter exploratório, constituindo-se de uma elaboração teórica que busca analisar a importância de uma formação continuada de docentes do Ensino Superior para atuar na EaD Online. As experiências formativas na modalidade, apesar de utilizarem diferentes ambientes de aprendizagem com interfaces que possibilitam uma comunicação mais interativa e cooperativa, continuam pautados em práticas pedagógicas baseadas numa educação instrucionista.

No texto seguinte, as autoras Francineide Alves Sales e Maria Lúcia Serafim têm como princípio o grande avanço das tecnologias da informação e comunicação na atualidade, em que se percebeu uma crescente busca pelo conhecimento aliada às formações de redes sociais. Este estudo investigou se os alunos estão utilizando as redes sociais para fins educativos, se professores que participam dessas redes colaboram para construção do conhecimento desses indivíduos e se este fato contribui para uma boa relação entre professores e alunos. O lócus da pesquisa foram duas escolas: uma da rede pública e outra da rede particular de ensino médio, sendo partícipes da pesquisa alunos do $1^{\mathrm{O}}$ ano do ensino médio. Os adolescentes apontaram que o Orkut e o MSN são as redes sociais mais acessadas e que o número de professores conectados aos alunos através de redes sociais ainda é pequeno quando se compara a evolução das tecnologias.

No quarto artigo Carolina Cavalcanti Bezerra e Lúcia Serafim apresentam os preceitos, fundamentos e características da infografia como ferramenta comunicativa propondo seu uso como metodologia de ensino na Educação a Distância. Os resultados alcançados e proposituras iniciais dessa leitura sugerem a utilização da infografia no desenvolvimento de atividades nos Ambientes Virtuais de Apren- 
dizagem e no processo de interação e mediação entre alunos, professores e tutores.

No artigo seguinte, os autores Robson Pequeno de Sousa e Karlete Vânia Mendes Vieira exploram a multimídia como uma ferramenta muito importante na comunicação e sua eficácia no aspecto educacional. O objetivo deste trabalho foi desenvolver e aplicar um Objeto de Aprendizagem baseado nos princípios da multimídia e aplicá-lo no ensino superior da Microbiologia. O estudo foi realizado com uma turma de alunos que cursou o segundo ano de Odontologia da Universidade Estadual da Paraíba. O Objeto de Aprendizagem demonstrou proporcionar uma boa assimilação do conteúdo através dos índices de acertos nos exercícios aplicados após cada módulo, segundo a escala de Likert. O sistema multimídia avaliado pode ser utilizado como recurso didático no ensino superior da Microbiologia, de maneira satisfatória.

No sexto trabalho desta coletânea, as autoras Luzivone Lopes Gomes e Filomena Maria G. S. Cordeiro Moita buscam analisar o uso das Tecnologias da Informação e Comunicação na prática docente em uma escola de Educação Básica. Foram realizadas entrevistas semiestruturadas com 26 professores, com coleta documental e observação in loco. Pesquisa com abordagem qualitativa, de cunho descritivo interpretativo, embasada na contribuição dos autores: Levy (1998); Tardif (2011); Moran (2010); Coscarelli (2006); Mattos (2010); Moita (2011); Valente (2010) e Dubet (2011). Assim buscou-se compreender como utilizar as tecnologias na prática docente, que impulsionam a educação para novos caminhos, buscando a melhoria do ensino e uma educação para formação de uma cidadania ativa.

Rodrigo Lins Rodrigues e Filomena Maria G. S. Cordeiro Moita destacam a introdução da Realidade Aumentada na educação 
como um novo paradigma que relata uma educação de forma dinâmica. Por isso, é importante estarmos atentos para essa nova tendência, bem como para esse novo receptor e suas necessidades. Nesse contexto, o objetivo foi propor uma estrutura para desenvolver um protótipo interativo para a visualização de figuras geométricas, com base em técnicas de realidade aumentada com rastreamento de mãos, que apoiará o professor e os alunos a visualizarem bem mais os conteúdos no campo da geometria espacial. Para tanto, foram utilizadas técnicas de análise de competidores, prototipagem e testes com o usuário. O resultado foi um protótipo funcional, que poderá ser utilizado no campo da Geometria e ser adaptado para outras áreas do conhecimento.

O texto a seguir de autoria de Maria Gracielly Lacerda de Abrantes e Robson Pequeno de Sousa intitulado "Formação Continuada e Conectivismo um estudo de caso referente às transformações da prática pedagógica no discurso do professor"recebeu como escolha metodológica os pressupostos da pesquisa qualitativa exploratória fazendo uso da aplicação de formulário do google drive, objetivando investigar como os professores participantes da formação continuada pelo PROINFO no curso Redes de Aprendizagem, promovido pelo Núcleo de Tecnologia Educacional, localizado na cidade de Patos, no segundo semestre de 2014 se apropriaram daquele conhecimento por meio das TIC.

É a partir desde cenário investigativo que o trabalho dos autores se fundamentou no estudo de George Simens (2004) sobre uma nova abordagem educacional que enfatiza a aprendizagem por meio de redes de conexão.

Pretende-se portanto com esta "amostra" de leitura disponibilizar aos que trabalham com formação de professores mais uma 
oportunidade de discussão sobre o uso das tecnologias da informação e comunicação no âmbito da educação.

Boa leitura,

\section{Prof a Dra Eliane de Moura Silva}

Pró-Reitora de Ensino Médio, Técnico e Educação a Distância 


\section{ALGUMAS CONSIDERAÇÕES SOBRE A}

FORMAÇÃO CONTINUADA DE PROFESSORES A PARTIR DAS NECESSIDADES FORMATIVAS EM NOVAS TECNOLOGIAS NA EDUCAÇÃO

\section{Laércia Maria Bertulino de Medeiros Carolina Cavalcanti Bezerra}

A tentativa de compreender a formação continuada de professores a partir do curso de Novas Tecnologias na Educação, promovido pela Universidade Estadual da Paraíba (UEPB), especificamente vinculado à Pró-Reitoria de Ensino Médio, Técnico e Educação a Distância (PROEA) constitui o objeto deste artigo que possibilita observar, dentre outros, as novas necessidades formativas que hoje, mais que em outras épocas, contribuem para inovações teóricas e uma provável ressignificação da prática pedagógica.

Nesse intento, busca-se articular este objeto com a importância da formação continuada, salientando brevemente as produções acadêmicas dos professores/alunos deste curso, problematizando e configurando o estudo no horizonte de um processo crítico que zela pela relação dialética teoria e prática.

No contexto da aprovação da Lei de Diretrizes e Bases da Educação Nacional (LDB - Lei 9394/96), da qual emergiram novas 
políticas de formação de professores, há tendências para a formação continuada que ao longo de décadas se concretizaram.

Historicamente, as décadas de 1980 e 1990 se configuraram numa época de crítica e superação aos anos anteriores no tratamento das políticas do ensino. A discussão em torno da formação do professor ganhou impulso, resultando em dois grandes movimentos: a revitalização do ensino e o de reformulação dos cursos de Graduação e maior fomento nas pós-graduações no Brasil.

Tendo como referencial a dimensão política da prática docente, a partir dos anos de 1980, emerge outra significação com a aprovação da nova Lei de Diretrizes e Base da Educação, em dezembro de 1996. Aprofundam-se as diferentes propostas para a formação de professores, com o objetivo de elevar os níveis de qualidade da educação. Na reforma do campo da formação, nunca se viu tanto empenho, por parte do governo e de setores das universidades em fazer cumprir o parágrafo $4^{0}$ do artigo 87 das Disposições Transitórias, da Nova LDB que diz: "Até o fim da Década da Educação somente serão admitidos professores habilitados em nível superior ou formados por treinamento em serviço"(BRASIL, 1996).

Nesse sentido, vê-se que paulatinamente se introduziram novos modelos de formação para o ensino superior: cursos sequenciais, educação a distância e outros programas de cunho acadêmico científico.

Em 2000, no X Encontro Nacional da Associação Nacional pela Formação dos Profissionais da Educação (ANFOPE) em Brasília, alertou-se sobre os problemas que as novas políticas governamentais poderiam trazer para a formação do professor:

[...] por entender que as propostas mantêm as fragmentações na formação que enfatiza exclusi- 
vamente o conteúdo específico, as metodologias e o projeto pedagógico da escola, a concepção conteudista, tecnicista do professor, reduzindo-o a um "prático" com pretenso domínio da solução de problemas da prática cotidiana da escola e da sala de aula, alijado da investigação e da pesquisa sobre as condições concretas que geram estes problemas (ANFOPE, 2000, p18).

Assim sendo, a prática do professor debate-se sobre diferentes projetos políticos e perspectivas históricas diferenciadas, o que faz com que a sua formação profissional seja tratada, dentre outras, como elemento impulsionador para a transformação da escola, da educação e da sociedade.

A adequação das Universidades em relação ao novo perfil da educação, apontado nas Diretrizes Curriculares Nacionais, teve no Plano de Desenvolvimento Institucional da UEPB a reforma curricular dos Cursos, além de destacar um novo conceito de gestão (19932000), ao tentar romper com toda a organização tradicional construída a sua volta. Pode-se sinalizar, por exemplo, a preocupação com a sintonia dos objetivos da educação científica com os componentes curriculares apontando para uma visão de educação básica voltada para a formação da cidadania.

Outro intento foi pensar estratégias de ensino que promovessem a interdisciplinaridade, além da proposta de uma multiplicidade de técnicas de ensino e estratégias didáticas com o intuito de possibilitar aos educandos a inserção nas questões sociais e ao interesse científico.

Com base nas discussões nacionais sobre formação docente, outro ponto crucial era pensar o perfil do professor formador voltado, efetivamente para uma nova concepção dos cursos de formação de professores e fomentar a sistematização e operacionalização entre 
ensino, pesquisa e extensão (BRASIL, 1999) como forma de também oferecer aos docentes da UEPB a possibilidade de formações em nível de pós-graduações.

Percebe-se que a formação de professores se confirma como relevante e indica o que Zeichner (2009; apud SLONGO; DELIZOICOV; ROSSET, 2009, p.101) já afirmara ao discorrer sobre essa temática apontando e recomendando a preparação de pesquisadores para estudarem a formação docente, justificando-se que 'Identificar as principais dimensões que precisam ser consideradas para compreender como a formação de professores contribui para determinados resultados educacionais."

Nesse sentido, alguns dos fundamentos teóricos centrais sobre formação de professores em novas tecnologias na educação, apresentados neste artigo, se filiam à perspectiva da teoria crítica e ao princípio freireano da ação-reflexão-ação, tomados como pressupostos que facilitam a efetivação da práxis pedagógica de forma transformadora.

Ao se tomar pressupostos teóricos e metodológicos que influenciam o pensar e o fazer na formação de professores, se reconhece que, como sujeitos do conhecimento, tentam legitimar seu repertório científico na construção e elaboração dessa formação, principalmente na formação continuada. Essa educação, no pensamento de Paulo Freire (1996), representa uma luta por novos significados quanto uma luta em torno de novas competências que assinalem um saber-fazer coerente com as novas demandas sociais.

O saber-fazer releva a importância do professor se assumir como protagonista na construção de alternativas, por ser alguém que processa informações, decide, gera conhecimento prático e possui uma cultura influente na sua atividade profissional. Como García 
(1999, p.47) mesmo confirma em suas palavras que é preciso "considerar o professor como 'um sujeito epistemológico'”. Portanto, há um percurso profissional que não limita o processo de formação docente ao momento de sua formação inicial.

É pertinente considerar o que Nóvoa (1988) discorre ao implicar o professor como adulto que aprende:

O adulto em situação de formação é portador de uma história de vida e de uma experiência profissional [...] Mais importante do que pensar em formar esse adulto é refletir sobre o modo como ele próprio se forma, isto é, o modo como ele se apropria do seu patrimônio vivencial através de uma dinâmica de compreensão retrospectiva (NÓVOA, 1988, p.128).

\section{A FORMAÇÃO CONTINUADA}

Ao se falar sobre formação de professores, percebe-se que historicamente uma concepção que se consolida é a formação continuada. No Brasil, a formação continuada de professores possui uma trajetória histórica e socioepistemológica marcada por diferentes tendências que emergiram de diferentes concepções de educação e sociedade presentes na realidade brasileira. Para Fusari (1998) e Nóvoa (1992), as ideias de formação continuada, vistas como etapa de um único processo:

[...] apontam para a necessidade de se avançar e criar um novo paradigma, no qual a formação do educador se efetive num continuum, processo em que a formação inicial, a formação contínua, a prática profissional, os saberes da profissão e a carreira profissional sejam elementos articulados entre si (FUSARI, 1998, p.538-9; NÓVOA, 1992). 
Na LDB 9394/96, a formação continuada tem por finalidade assegurar aos profissionais da educação o aperfeiçoamento da profissão por meio da intervenção institucional pública (municipal ou estadual), como rezam os artigos:

Artigo 87 (das disposições transitórias) - Cada município e supletivamente, o Estado e a União, deverá:

Parágrafo III- realizar programas de capacitação para todos os professores em exercício, utilizando, também para isso, os recursos da educação a distância.

Artigo 67 (dos profissionais da educação) - Os sistemas de ensino promoverão a valorização dos profissionais da educação, assegurando-lhes, inclusive nos termos dos estatutos e dos planos de carreira do magistério publico (BRASIL, 1996).

Nitidamente nas três últimas décadas, principalmente a partir das políticas para a Educação em todos os níveis, há um incentivo para os profissionais de a educação continuar aprendendo sobre seu campo profissional. A formação continuada passou a "ser considerada como uma das estratégias fundamentais para o processo de construção de um novo perfil profissional de professor"(SILVA; ARAÚJO, 2005; ALTEL, 2001; CANDAU; LELIS, 1999; VEIGA, 1998; ESTRELA; GATTI, 1997; FREIRE, 1996; PIMENTA, 1995; NÓVOA, 1991).

Essa reconfiguração na formação de professores tem repercutido atualmente na construção de identidade do professor, pois revela dentre outras a formalização do saber/dizer científico dos docentes, no seu saber/fazer. Segundo Altet:

A formação não pode mais consistir em uma modelização das tomadas de decisão, mas deve propor dispositivos variados e complementares que desenvolvam o saber-analisar, o saber - refletir, o saberjustificar, através de um trabalho do professor so- 
bre suas próprias práticas e experiências (ALTET, 2001, p.34).

Partindo do pressuposto que a formação do docente deve levá-lo a uma prática social crítica, a formação centralizada numa prática social na ação-reflexão-ação é algo que alimenta a tomada de consciência e de conhecimento por parte do educador.

No entender de Pimenta (1995, p.14), a formação do docente não se esgota nos cursos de formação, pois um curso não é a práxis do futuro professor, ou seja, "um curso não é a prática docente, mas é a teoria sobre a prática docente e será mais formador à medida que as disciplinas todas tiverem como ponto de partida a realidade”.

Em Freire (1996), a formação continuada tem como objetivo incentivar a apropriação dos seus saberes rumo a uma autonomia que o leve de fato a uma prática crítico-reflexiva. Sobre isso afirma que:

Na formação permanente dos professores, o momento fundamental é o da reflexão crítica sobre a prática. É pensando criticamente sobre a prática de hoje ou de ontem que se pode melhorar a próxima prática. O próprio discurso teórico, necessário à reflexão crítica, tem de tal modo concreto que quase se confunde com a prática. O seu "distanciamento" epistemológico da prática, enquanto objeto de sua análise, deve dela "aproximá-lo" ao máximo (FREIRE, 1996, p.39).

No pensamento freireano, a ideia de formação continuada deriva a partir da "condição de inacabamento do ser humano e a consciência desse inacabamento"(FREIRE, 1996, p.40). Diante disso, a formação continuada baseia-se em um processo sucessivo do desenvolvimento profissional do professor formador perante uma interligação entre sua formação inicial, correspondente a sua vivência de aprendi- 
zagem nas instituições formadoras e a continuada, que se configura como processo durante o exercício da profissão.

Segundo Delizoicov (2002 apud RÊGO, 2006, p.80), considerar o professor como sujeito da sua história significa instrumentá -lo para atuar sobre sua prática, envolvendo-o em todos os momentos dessa formação, reconhecendo-o como sujeito de sua prática. Assim, pensar a formação continuada é levar em conta os saberes já constituídos dos professores e as especificidades de suas práticas pedagógicas.

Tardif (2002) afirma que tanto em suas bases teóricas quanto em suas consequências práticas, os conhecimentos profissionais são evolutivos e progressivos e necessitam, por conseguinte, de uma formação contínua e continuada.

\section{UNIDADE ENTRE TEORIA E PRÁTICA}

A concepção e o entendimento da teoria e prática se dão de diferentes formas no que diz respeito aos cursos de formação docente, isto é, circundam pensamentos que veem essa relação ora como opostas, ora como uma relação de justaposição, ora como uma relação de unidade.

Para Freire (1983), a unidade teoria e prática são práxis, isto é, são a ação e a reflexão dos homens sobre o mundo para transformá -lo. E é nesse sentido, que teoria e prática são indissociáveis. Assim, ao se refletir criticamente sobre as novas tecnologias na educação se vislumbra, de fato, como mais um elemento acadêmico científico que na atualidade se faz necessário para o campo da formação do educador.

Pimenta (1995) conceitua práxis inspirada em diversos teóricos, dentre eles Marx que, conceitua práxis como uma atitude teórico-prática do homem de transformação da natureza e da sociedade. 
Não basta conhecer e interpretar o mundo (teórico) é preciso transformá-lo (práxis). Vê-se que práxis se dá num processo dialético que é intencional, consciente e concreto pela ação e reflexão do homem sobre a realidade (CANDAU; LELIS, 1999).

Vasquéz (1977, p.185) ao conceituar práxis diz que: “Toda práxis é atividade, mas nem toda atividade é práxis". Para tanto, a relação entre teoria e prática apresenta-se sob alguns aspectos que são: a prática como fundamento da teoria; a teoria onipotente sobre a prática; a prática como critério de verdade; a prática como atividade subjetiva e objetiva.

Pode-se depreender que, no primeiro aspecto citado, a prática determina a teoria, [....] já que determina o horizonte de desenvolvimento e progresso do conhecimento"(VASQUÉZ, 1977, p.215). É a prática concreta que revela para a teoria seu critério de verdade ou não, pressupondo uma vinculação entre ambas.

Evidencia-se, portanto, que a prática não existe "sem um mínimo de ingredientes teóricos”. De acordo com Vasquéz são:

a) um conhecimento da realidade que é objeto de transformação;

b) um conhecimento dos meios e de sua utilização - da técnica exigida em cada prática -, com que se leva a cabo essa transformação;

c) um conhecimento da prática acumulada, em forma de teoria que sintetiza ou generaliza a atividade prática na esfera em que ela se realize, posto que o homem só pode transformar o mundo a partir de um determinado nível teórico, ou seja, inserindo sua práxis atual na história teórico prática correspondente;

d) uma atividade finalista, ou antecipação dos resultados objetivos que se pretendem atingir sob a forma de finalidades ou resultados prévios, ideais, com a particularidade de que essas finalidades, para que possam cumprir sua função prática, têm 
de corresponder à necessidade e condições reais, têm de tomar conta da consciência dos homens e contar com os meios adequados para sua realização (VASQUÉZ,1977, p.240).

A prática como atividade objetiva e subjetiva vista por Vasquéz (1977, p.242-243) é simultaneamente objetiva e subjetiva, na medida em que "o sujeito não prescinde de sua subjetividade, mas também não se limita a ela; é prático na medida em que se objetiva, e seus produtos são a prova objetiva de sua própria objetivação.”

Nesse sentido, esse movimento não é desprovido de uma intencionalidade consciente, ou seja, a finalidade no processo prático é eminentemente resultado de uma consciência que é dialética:

A prática requer um constante vai-e-vem de um plano a outro, o que só pode ser assegurado se a consciência se mostrar ativa ao longo de todo processo prático. Resulta daí que se é certo que a atividade prática, sobretudo como práxis individual, é inseparável dos fins que a consciência traça, esses fins não se apresentam como produtos acabados, mas sim num processo que só termina quando a finalidade ou resultado ideal, depois de sofrer mudanças impostas pelo processo prático, já é um produto real (VASQUÉZ, 1977, p.243).

A esse respeito, Freire (1983, p.38) acrescenta que: 'Não se pode pensar em objetividade sem subjetividade. Não há uma sem a outra, que não podem ser dicotomizadas”.

A prática como critério de verdade é outro aspecto que é amplamente discutido por Pimenta (1995), ao explicitar o entendimento da unidade teoria e prática sobre a investigação dialética na pesquisa científica que vê o papel da práxis na educação sob quatro aspectos: a intencionalidade da prática; a sua natureza; a necessidade da ação conjunta; e a sua realização efetiva como trabalho humano. 
A intencionalidade da prática refere-se a um fazer consciente, isto é, de acordo com finalidades sobre o mundo concreto num movimento que é dialético.

Outro ponto que se constitui em critério de verdade é a prática social, porque todo o conhecimento e toda ciência só têm fundamento se os fatos que o determinam forem sociais, isto é, sua finalidade, sua construção, seus fins e seus agentes são sociais.

A prática também é uma ação conjunta na medida em que a resolução de problemas científicos complexos pede um envolvimento coletivo dado à profundidade de uma solução individualizada. Vale salientar que o mesmo trabalho pode se dar na ação docente.

Por fim, a prática e a sua realização efetiva como trabalho humano se caracterizam como social, sobretudo, porque é entendida como a ação transformadora da realidade. Assim, a relação de unidade entre teoria e prática é práxis e se dá concretamente na relação intencional, coletiva e social do homem com a realidade que o circunda.

\section{CONTRIBUIÇÕES DA ESPECIALIZAÇÃO EM NOVAS TECNOLOGIAS NA EDUCAÇÃO DA UEPB: AS PRODUÇÕES CIENTÍFICAS}

Ao percorrer teoricamente sobre a formação continuada, faz-se um recorte a respeito da produção científica do curso de Especialização em questão, especificamente no que concerne aos trabalhos de conclusão. Conhecer minimamente o que se produziu ao final de uma jornada revela, dentre outros, o que se configura como temáticas de relevância, como verificar o que ainda é necessário caminhar.

Fez-se um levantamento de dados na biblioteca do polo de Educação a Distância da UEPB em Campina Grande, resultando em 
43 produções de trabalhos de conclusão de curso, no período de 2008 a 2012. Os aspectos balizadores para análise das modalidades de produções foram as temáticas predominantes.

As 43 produções de trabalho de conclusão foram distribuídas em grupos. Criaram-se as seguintes categorias temáticas: Áreas do Conhecimento; Recursos de Multimídia para o Ensino; Jogos Digitais; Formação de Professores; Educação a Distância; Desenvolvimento e Avaliação de Sistema Multimídia; Gestão no Ensino; Sujeitos do Processo de Ensinar e Aprender; Políticas Públicas e Institucionais e os Processos Educativos; Currículo nos Lugares e Espaços Educativos.

CATEGORIA 1: Áreas do conhecimento explicitadas

Foram 17 trabalhos classificados nessa categoria que aqui se definem como "a condição de organização, reorganização, alargamento, aprofundamento e revisão do conhecimento"(BAIBICH-FARIA, 2009, p.735). Essa condição resultou na tabela abaixo:

Quadro 1 - Categoria: áreas do conhecimento explicitadas (continua)

\begin{tabular}{|c|c|c|}
\hline TEMÁTICAS & ANO & TOTAL \\
\hline Geografia & 2008 & 4 \\
\hline Geografia & 2010 & 1 \\
\hline Administração & 2008 & 1 \\
\hline Administração & 2010 & 1 \\
\hline História & 2008 & 1 \\
\hline Matemática & 2008 & 1 \\
\hline Matemática & 2012 & 1 \\
\hline Língua portuguesa & 2008 & 1 \\
\hline Química & 2008 & 1 \\
\hline
\end{tabular}




\begin{tabular}{|c|c|c|}
\hline Microbiologia & 2010 & 1 \\
\hline Ciências Biológicas & 2008 & 1 \\
\hline Comunicação e Educação & 2010 & 1 \\
\hline Geometria & 2010 & 1 \\
\hline Informática & 2011 & 1 \\
\hline
\end{tabular}

FONTE - Arquivo das pesquisadoras

CATEGORIA 2: Uso de recursos e ferramentas didáticas

Define-se essa categoria como a utilização de instrumentos que podem facilitar a construção do conhecimento na prática pedagógica e na pesquisa. Eis a tabela com as referências:

Quadro 2 - Categoria: ferramentas didáticas

\begin{tabular}{|c|c|c|}
\hline TEMÁTICAS & ANO & TOTAL \\
\hline Multimídia para o ensino & $2008 / 2010(2)$ & 4 \\
\hline Ambiente virtual de aprendizagem & 2008 & 2 \\
\hline Jogos digitais & 2008 & 3 \\
\hline Vídeo digital & 2008 & 1 \\
\hline Moodle & 2008 & 1 \\
\hline Tabela periódica eletrônica & 2010 & 1 \\
\hline Infografia & 2010 & 1 \\
\hline Orkut & 2010 & 1 \\
\hline WEBQUEST: & 2010 & 1 \\
\hline Redes Sociais & 2010 & 1 \\
\hline O uso do GVSIG & 2010 & 1 \\
\hline Régua e compasso: software da geometria & 2010 & 1 \\
\hline Webcurrículo & 2012 & 1 \\
\hline
\end{tabular}

FONTE - Arquivo das pesquisadoras 
CATEGORIA 3: Centralidade na educação a distância

Essa categoria é aqui definida como tentativa de compreensão da modalidade de ensino e suas variantes acerca do processo educativo.

Onze (11) trabalhos de conclusão de curso tratam da temática educação a distância sob várias perspectivas. Assim, aqui se optou por listar na íntegra os títulos:

1. A utilização do ambiente virtual de aprendizagem em curso superior a distância;

2. Limites e possibilidades no uso do ambiente de aprendizagem do curso de Geografia a distância;

3. Panorama da educação superior a distância no Brasil: um estudo exploratório.

4. Educação a distância e sua relevância na inclusão social na Universidade Estadual da Paraíba - UEPB;

5. Tutoria: concepções e práticas na educação a distância;

6. O sociointeracionismo no contexto da EAD. A experiência da UFRN;

7. Moodle no curso de ciências biológicas a distância: análise das contribuições no processo de ensino e aprendizagem;

8. Avaliação online na educação a distância: recurso para uma avaliação contínua dos alunos da UEPB do curso de graduação em Administração a distância;

9. Educação a distância. Currículo e interculturalismo: percepção de professores do curso de licenciatura em Geografia;

10. Alunos de EAD: refletindo sobre os ambientes virtuais no curso de Geografia EAD/UEPB; 
11. Gestão em EAD no Ensino Superior: uma avaliação do curso piloto de graduação em administração da SEAD/UEPB.

CATEGORIA 4: Educação, novas tecnologias e outras demandas sociais.

Essa categoria é aqui definida como influência na compreensão das novas tecnologias e seu impacto na educação, na história, na formação pessoal, na formação do professor e do estudante, na inclusão social e gestão.

Catorze (14) trabalhos tratam da temática sob as perspectivas citadas. Aqui também se optou por listar na íntegra os títulos:

1. As concepções de interatividade nos ambientes virtuais de aprendizagem;

2. Ações e estratégias públicas para implementação e o uso de computadores na educação;

3. As novas tecnologias da informação e comunicação no ensino médio profissionalizante: novas perspectivas para a educação e o trabalho;

4. As novas tecnologias da educação frente à inclusão social: um estudo em Campina Grande-PB;

5. Desenvolvimento e avaliação de sistema multimídia para ensino e aprendizado em topografia;

6. A resistência do professor diante das novas tecnologias educacionais;

7. Educação especial em novas tecnologias: caminha para a inclusão?

8. Educação ambiental e tecnologia: aplicação de um SIG na identificação de áreas para aterro sanitário - o uso do GVSIG; 
9. A utilização de recursos multimídias e outras tecnologias para dinamizar o processo de ensino aprendizagem na educação de jovens e adultos;

10. Do volume à tela - O livro, o leitor e a leitura dos primórdios à era digital;

11. Realidade aumentada aplicada à educação: desenvolvimento de um protótipo utilizando rastreamento de mãos;

12. "A fazenda"e a lógica matemática [manuscrito]: a tecnologia no processo de aprendizagem de crianças autistas;

13. Web currículo [manuscrito]: nova cultura de aprender;

14. O uso das novas tecnologias na implementação de projetos inovadores.

Esses trabalhos resultam na síntese consistente do que se considera representativa de uma comunidade epistêmica (ANTONIADES, 2003) e, ao mesmo tempo, a apresentação e as discussões sobre as variantes do conhecimento a partir da especialização em Novas Tecnologias na Educação. 


\section{CONSIDERAÇÕES}

Os trabalhos científicos produzidos pelas comunidades epistêmicas 'têm, potencialmente, a capacidade de influenciar textos políticos e a formação de professores nos contextos de produção de políticas”(LOPES, 2006, p.33-52). Destacou-se, no texto, a importância da formação continuada e os dados disponíveis da produção científica dos trabalhos de conclusão de curso da Especialização em Novas Tecnologias da Educação, da Universidade Estadual da Paraíba.

Ponderou-se sobre a relevância de se considerar as Novas Tecnologias como uma das fontes que podem estar na base do conhecimento da Educação e, assim, sobre a necessidade de pensá-la a partir de sua interseção com outras ciências e com a prática pedagógica.

O diálogo com outras áreas do conhecimento, articuladas com as novas demandas dos cursos de formação, contribui e favorece o trabalho docente dos próprios formadores, a partir do momento em que se mobilizam saberes vindos de fontes heterogêneas.

Em pesquisa realizada por Onofre (2000), ficou demonstrado que o desenvolvimento de programas de formação destinados a professores atuantes pode apresentar um avanço para o campo da formação continuada, uma vez que, privilegiando a troca de experiências e a reflexão sobre a prática tende a tornar a proposta atualizada e pertinente às dificuldades dos docentes.

Assim, sabe-se que qualquer programa de formação continuada se encontra em constante construção, decorrente do próprio princípio articulador entre teoria e prática. Nesse sentido, é que a formação continuada tem se caracterizado como tendência enriquecedora ao desenvolvimento profissional docente. 
Dessa forma, buscou-se resumidamente levantar dados do universo apontado, assim como, algumas reflexões sobre as necessidades formativas dos docentes para atender às novas demandas educacionais.

\section{REFERÊNCIAS}

ALTET, M. et. al. Formando professores profissionais: quais estratégias? Quais competências? 2.ed. Porto Alegre: Artmed Editora, 2001.

ANTONIADES, A. Epistemic comunities, epistemes and the constructions of (world) politics. Global Society, v.17, n.1. Kent: Inglaterra, 2003.

ASSOCIAÇÃO NACIONAL PELA FORMAÇÃO DE PROFESSORES - ANFOPE. Políticas Públicas de formação de profissionais da educação: desafios para a instituição do ensino superior. Documento final do X Encontro Nacional da Associação Nacional pela Formação dos Profissionais da Educação. Brasília, 2000.

BAIBICH-FARIA, T. M. A dimensão teórica da formação dos formadores em didática e práticas de ensino: influências no pensamento contemporâneo e repercussões nas práticas de formação. Avaliação, v.14, n. 3, p.727-753, Campinas: Sorocaba, 2009.

BRASIL. Ministério de Educação e Cultura. Secretaria de Educação Fundamental. Referenciais para formação de professores. Brasília: MEC/SEF, 1999. 
Lei 9394/96, de 23 de dezembro de 1996. Lei de Diretrizes e Bases para a Educação Nacional. Diário Oficial da União. Brasília, DF, 1996.

CANDAU, V. M; LELIS, I. A. A relação teoria-prática na formação do educador. In. CANDAU, V. M. (org). Rumo a uma nova didática. 9.ed. Petrópolis: Vozes, 1999.

ESTRELA, M. T. Viver e construir a profissão docente. Porto: Porto Editora, 1997.

FREIRE. P. Pedagogia da autonomia: saberes necessários à prática educativa. 37.ed. São Paulo: Paz e Terra, 1996.

Pedagogia do oprimido. 13.ed. Rio de Janeiro: Paz e Terra, 1983.

FUSARI, J. C. Formação contínua de professores: o papel do Estado, da universidade e do sindicato. In: ENCONTRO NACIONAL DE DIDÁTICA E PRÁTICA DE ENSINO, 9., 1998, Águas de Lindóia. Conferências, mesas-redondas e simpósios. Petrópolis: Vozes, 1998.

GARCÍA, C. M. Formação de professores: para uma mudança educativa. Porto: Porto Editora, 1999.

GATTI, B. Formação de professores e carreira: problemas e movimentos de renovação. Campinas: Autores Associados, 1997. 
LOPES, A. C. Discursos nas políticas de currículo. Currículo sem fronteiras, v. 6, n. 2, p.33-52, jul./dez.2006. Disponível em: 〈http:// www.curriculosemfronteiras.org/vol6iss2articles/lopes.pdf〉. Acesso em 12 jan. 2013.

NÓVOA, A. Formação de professores e profissão docente. In:

Os professores e a sua formação. Lisboa: Dom Quixote, 1992. p.1333.

Para o estudo sócio-histórico da gênese e desenvolvimento da profissão docente. In. Teoria \& Educação, n.4, p.109 - 133. Campinas, 1991.

NÓVOA, A.; FINGER, M. O método (auto) biográfico e a formação. Lisboa: Ministério da Saúde, 1988.

ONOFRE, M. R. O programa de educação continuada da SEE/SP: 1997-1998 na visão de docentes formadores, professores participantes e especialistas de educação. 2000. 165f. Dissertação (Mestrado) Faculdade de Ciências e Letras, UNESP, Araraquara.

PIMENTA, S. G. O estágio na formação de professores: unidade teoria e prática? 2.ed. São Paulo: Cortez, 1995.

RÊGO, M. C. F. D. A formação docente no fazer e refazer da prática pedagógica. 2006. 71f. Tese (Doutorado) - Centro de Ciências Sociais Aplicadas, Universidade Federal do Rio Grande do Norte, Natal - RN. 
SILVA, E. M. A.; ARAÚJO, C. M. Reflexão em Paulo Freire: uma contribuição para a formação continuada de professores. V Colóquio Internacional Paulo Freire. Recife, 19 a 22 de setembro 2005.

SLONGO, I. I. P.; DELIZOICOV, D.; ROSSET, J. M. A formação de professores nas atas do ENPEC: uma análise preliminar. In: ENCONTRO NACIONAL DE PESQUISA EM EDUCAÇÃO E CIÊNCIAS, VII, 2009, Florianópolis-SC. Anais Eletrônicos. Florianópolis: ABRAPEC, 2009. CD-ROM

TARDIF, M. Saberes docentes e formação profissional. Petrópolis: Vozes, 2002.

VASQUÉZ, A. S. Filosofia da práxis. 2.ed. Rio de Janeiro: Paz e Terra, 1977.

VEIGA, I. P. A. Escola: espaço do projeto político-pedagógico. 4.ed. Campinas: Papirus, 1998.

ZEICHNER, K. M. Uma agenda de pesquisa para a formação docente. Revista Brasileira de Pesquisa sobre Formação Docente, v.1, n.1, p. 1-28, ago/dez. Belo Horizonte, 2009. Disponível em: 〈http://www. formacaodocente.autenticaeditora.com.br $\rangle$. Acesso em 08 set. 2010. 


\author{
Taíses Araújo da Silva Alves \\ Robson Pequeno de Sousa
}

\title{
INTRODUÇÃO
}

As instituições educacionais contemporâneas, frente às constantes transformações que vêm ocorrendo na nossa sociedade, principalmente no que concerne à presença das tecnologias da informação e comunicação, têm sido desafiadas a repensar sobre suas práticas. Dentre essas modificações, podemos citar as questões econômicas e culturais, que se desdobram em novas formas de apreensão espaço/temporal, no surgimento de novos postos de trabalho, na crise do conhecimento, na digitalização da informação e na emergência da cibercultura.

O desenvolvimento das Tecnologias Digitais de Informação e Comunicação (TDIC) e com elas o avanço da Educação Online constituem uma realidade que não pode ser ignorada na formação inicial ou continuada de professores, sob pena de se desconsiderar as mudanças dos meios de comunicação e a eficácia de sua aplicabilidade na sociedade, de modo geral, e na educação em particular.

Atualmente, uma das principais preocupações das pesquisas em $\mathrm{EaD}$ está no processo de aprender porque esse processo ganha 
um novo significado em função dos conhecimentos que terão de ser construídos e reconstruídos de forma constante pelos indivíduos, implicando no desenvolvimento de habilidades consideradas fundamentais para atuarem de forma efetiva na sociedade contemporânea.

A Educação Online traz consigo características próprias que impõem a necessidade de novas aprendizagens, o que implica na necessidade de que seja construída uma nova maneira de compreender o processo de ensino-aprendizagem.

Diante da fecundidade de discussões sobre as especificidades da atuação docente no contexto do ciberespaço, e considerando a demanda para a formação de educadores preparados para atuar neste novo paradigma educacional, surgem as seguintes questões: Como pensar ensino e aprendizagem nesse cenário? Como estruturar a docência preservando o protagonismo e a condição ativa do aprendiz e, ao mesmo tempo, proporcionar-lhe experiências significativas? Enfim, o que considerar numa formação de professores para o trabalho com Educação Online?

Nosso estudo trata-se de uma Pesquisa Qualitativa de caráter exploratório, constituindo uma elaboração teórica que busca refletir sobre a importância da formação continuada de docentes do Ensino Superior para atuar na Educação Online. Para consecução desse objetivo iremos: refletir sobre as mudanças no processo de ensino-aprendizagem na Educação a Distância com o advento das TDIC; investigar as especificidades da Educação Online, desenvolvida através de Ambientes Virtuais de Aprendizagem; compreender o papel do professor na Educação Online; tecer reflexões sobre alguns aspectos a serem considerados na formação dos professores para esta modalidade. 
O presente estudo está estruturado em seis partes, além desta Introdução. A primeira parte apresenta uma discussão sobre o processo de Ensino e Aprendizagem na Sociedade em Rede e os desafios da educação, advindos com a Sociedade da Informação. A segunda parte discute sobre a evolução da Educação a Distância e o advento da Educação Online. A terceira parte apresenta a metodologia de pesquisa. A quarta parte reflete sobre a formação dos professores para atuar na Educação Online, apresentando alguns aspectos a serem considerados quando do desenvolvimento de propostas formativas para os docentes que atuarão em ambientes virtuais e por fim as considerações finais e referências.

\section{TECNOLOGIAS E EDUCAÇÃO A DISTÂNCIA}

Desde os primórdios da sociedade, a tecnologia sempre afetou o homem: das primeiras ferramentas, por vezes consideradas extensões do corpo, à máquina a vapor, que mudou hábitos e instituições; ao computador, que trouxe novas e profundas mudanças sociais e culturais; às redes informáticas, que estão criando novas formas de relações humanas. Nesse sentido, a tecnologia ajuda, completa e amplia. Ora fascina, ora assusta.

Para Belloni (2002), o uso de uma tecnologia (no sentido de artefato técnico), em situação de ensino e aprendizagem, deve estar acompanhado de uma reflexão sobre a mesma (no sentido do conhecimento embutido no artefato e em seu contexto de produção e utilização), o que reforça a necessidade de assegurar sua dupla dimensão como ferramenta e objeto de estudo e reflexão. Isso significaria ser capaz de realizar um deslocamento de enfoques: do enfoque pragmático para um enfoque criativo. Para realizar tal deslocamento, seria 
necessário ir além das dualidades, construindo novos enfoques de natureza multidisciplinar.

Tal mudança de enfoque no uso das TDIC vem se desenvolvendo no mundo inteiro, desde os anos 70, de uma concepção instrumental de tecnologia educacional para uma concepção de comunicação educacional integradora que considere sua dupla dimensão (instrumental e conceitual; ética e estética). Trata-se de educação para as mídias, cujos objetivos dizem respeito à formação do usuário ativo, crítico e criativo de todas as tecnologias de informação e comunicação (BELLONI, 2002).

Cabe acrescentar, ainda, que é essencial ensinar-aprender a conviver com relações complexas geradas pela inserção da tecnologia na sociedade e espera-se que, no âmbito da educação, os novos modos de pensar possibilitam o diálogo entre o pensamento lógico e a sensibilidade, entre a sensação e a intuição.

Em EaD, a utilização dos meios técnicos não reduz os outros componentes do processo educativo (tanto os técnicos como os humanos) a algo secundário. Pelo contrário, estes meios são ferramentas para uma educação eficaz, sobretudo quando se trata de educação para um grande número de pessoas.

Atualmente, a tecnologia educacional está em função da intensificação do uso das Tecnologias de Informação e Comunicação (TIC). Comunicação e educação estão cada vez mais interdependentes, o que constitui para o educador um grande desafio na dimensão pedagógica de sua atividade técnico-científica.

A discussão em torno das TIC na educação não são necessariamente decorrentes da $\mathrm{EaD}$. O desenvolvimento da $\mathrm{EaD}$ e sua viabilidade é que estão historicamente ligados ao desenvolvimento das tecnologias, podendo ser identificadas diversas gerações de EaD, 
interligadas para promover o processo de interlocução entre alunos e professores: impressa, audiovisual e telemática.

\section{ENSINO E APRENDIZAGEM NA SOCIEDADE DA INFORMAÇÃO}

Durante as últimas décadas, as instituições educacionais vêm passando por um processo de mudança muito significativo, com destaque para o crescimento da Educação a Distância no processo educacional. Os paradigmas presentes na sociedade já não dão conta das relações, das necessidades e dos desafios sociais. Vive-se atualmente na 'Sociedade em Rede", uma sociedade que dá ênfase à cultura da aprendizagem, convergindo para a construção de um novo modelo (BEHAR, 2009).

Os novos sistemas de comunicação, advindos com a Sociedade da Informação, propiciam o surgimento de formas diferentes de conhecer e de estabelecer relações que permitem a expressão das ideias por meio de distintas linguagens e da construção do pensamento. O ciberespaço é o novo meio de comunicação onde se conectam os computadores e se abriga o mundo de informações, formando uma "rede"que permite às pessoas "navegar", disponibilizar suas ideias e trocar informações (LEVY, 1999).

A sociedade da informação, do conhecimento, da aprendizagem, em que vivemos, modifica a vida dos cidadãos em inúmeros planos, assim como os cenários, os meios de produção, o que repercute sobre os processos de aprender e de ensinar com tecnologias nas instituições de ensino superior - em tais cenários, reconfigurados pela acelerada evolução tecnológica, não há propostas únicas nem é desejável que se atenda a todos da mesma maneira, de modo que qualquer pro- 
posta de formação reveste-se de inquietudes trazidas pelos matizes e incertezas das novas e complexas possibilidades.

\section{DESAFIOS DA SOCIEDADE DA INFORMAÇÃO PARA A EDUCAÇÃO}

As transformações ocorridas na sociedade, em grande parte como decorrência dos avanços tecnológicos, produziram alterações profundas em todos os setores da vida humana, exigindo adaptações rápidas, que por sua vez requerem conhecimentos e habilidades distintos daqueles já consolidados. A rapidez no fluxo das informações, associada aos sofisticados meios de comunicação, coloca as pessoas diante de situações que desafiam a sua inteligência e suscitam novas aprendizagens. O conhecimento, elemento central para a organização e desenvolvimento da sociedade, é ao mesmo tempo o grande motivador e uma grande incógnita, dada a complexidade e provisoriedade.

As instituições educativas não conseguem dar conta de proporcionar toda a informação relevante e necessária para os estudantes, desta forma o mais importante é formar os aprendizes para terem acesso a ela na medida de suas necessidades, ou seja, prepará-los para continuarem aprendendo sempre. Educar, portanto, não pode implicar tão somente transmissão de informações, assegurando que elas sejam retidas na memória para serem utilizadas em outras oportunidades, uma vez que, a qualquer momento, elas poderão deixar de ser importantes e significativas. O que importa na verdade é que o aprendiz seja capaz de trabalhá-las de forma crítica, para poder utilizá-las na solução de problemas.

No bojo das mudanças tecnológicas, culturais e científicas não há como prever quais serão os conhecimentos necessários para 
viver em sociedade e inserir-se no mundo do trabalho daqui a alguns anos. Essas considerações sobre a aprendizagem tornam clara a ideia de que os aprendizes deverão ser preparados para gerir o processo de construção do conhecimento, aprendendo a aprender ao longo da vida.

Mudar as formas de aprender dos alunos requer também as formas de ensinar dos seus professores. Por isso, a nova cultura de aprendizagem exige um novo perfil de aluno e do professor, exige novas funções discentes e docentes, as quais só se tornarão possíveis se houver uma mudança de mentalidade (POZZO, 2004, p.11).

\section{NOVAS FORMAS DE APRENDER}

A sociedade, chamada por alguns pensadores de Sociedade da Informação, por outros de Sociedade do Conhecimento ou ainda Sociedade da Aprendizagem, caracteriza-se pela rapidez e abrangência de informações. A realidade do mundo atual requer um novo perfil de profissional e cidadão que coloca para as instituições educacionais novos desafios. No cotidiano, encontram-se situações que demandam o uso de novas tecnologias que provocam transformações na nossa maneira de pensar e de nos relacionarmos com as pessoas, com os objetos e com o mundo ao redor.

O desafio atual do sistema educacional é formar os alunos para a cidadania responsável e para que sejam contínuos aprendizes, que tenham autonomia na busca e seleção de informações para aprender a aprender ao longo da vida.

Os alunos precisam ser preparados para utilizar os sistemas culturais de representação do pensamento que marcam a sociedade contemporânea, o que implica em novas formas de letramento ou 
alfabetização (sonora, visual, hipermídia...) próprias da cibercultura, além das demais formas já conhecidas (SANTOS, 2005).

A exigência de aprender continuamente ao longo da vida constitui na sociedade atual um desafio para todas as pessoas e uma necessidade premente colocada aos educadores. Não se trata apenas de ter acesso a informações, mas sim de saber buscá-las em diferentes fontes e, sobretudo, transformar as informações em conhecimentos para resolver problemas da vida e do trabalho.

Integrando-se em redes de comunicação, os indivíduos acabam por tornar informação e conhecimento um bem comum e a produtividade intelectual artística e científica alcança dimensão universal: o conhecimento passa a pertencer a todos e todos podem utilizá-lo, de modo que a educação pode contribuir para redistribuir a riqueza do conhecimento e para o desenvolvimento pessoal (SILVA, 2003).

Garantido o acesso às informações, organizam-se redes de interação apoiadas nas tecnologias disponíveis, o que acaba por alterar forma e conteúdo do trabalho, provocando a renovação dos locais de trabalho e estudo (MELLO, 2003 apud PORTO, 2003). As TIC trazem novas formas de compreensão e expressão da realidade que de certa forma podem ser utilizadas para reprodução de mensagens ou interatividade, síncrona ou assíncrona.

No contexto da EaD online, o aluno pode estudar, interagir com outros alunos, professores, tutores e instituição, refletir e aprender em local e horário de sua escolha, bastando para isto ter acesso a um computador conectado à internet. Sobre isto, Silva (2003) afirma que a EaD online é uma exigência da cibercultura, isto é, do novo contexto socioeconômico-tecnológico. 


\section{NOVOS MODOS DE ENSINAR}

Diante dessa nova realidade do saber e do conhecimento veloz, provisório, dinâmico, o professor precisa redefinir o seu papel, rever seus paradigmas de aprendizagem e ensino, rever sua postura diante da realidade que o circunda e buscar novas alternativas para entrar em sintonia com o mundo contemporâneo que aí está e que exige dele uma redefinição da sua identidade profissional.

Na modalidade de Educação a Distância, a figura do professor não é eliminada. Ao contrário, passa a ser um elemento chave, porque sem ele os cursos oferecidos, através dessa modalidade de ensino, correm o risco de não formar, ou apenas informar o aluno sobre os conteúdos ofertados. A informação, pura e simples, pode ser apenas um adorno, uma estratégia para gerir o indivíduo no espaço social, mas, se não houver alguém que conduza um processo educativo, que mobilize e dinamize o acesso dessa informação, não haverá a produção e a criação do conhecimento desejado. É nesse ponto que a educação difere da informação. A educação propicia ao indivíduo o desenvolvimento do senso crítico, da capacidade de criar seu próprio saber, fundamental ao seu desenvolvimento social, cultural, ético e cidadão.

Segundo Santos (2005), as redes, não só de máquinas e de informação, mas principalmente de pessoas, tribos e comunidades, estão permitindo configurar novos espaços de interação e de aprendizagem. Tais possibilidades estão pondo, em xeque, o papel e o "poder centralizador" dos professores na contemporaneidade. Não há mais emissores (professores) e receptores (estudantes) como dois grupos distintos com mensagens estáticas e, sim, um grande grupo interagindo que pode constantemente reconstruir conhecimentos. 
A formação de comunidades cooperativas de trabalho e aprendizagem em rede, presenciais e/ou virtuais, fica favorecida e elas podem influir sobre o aprender e se disseminar na sociedade, incorporando novos participantes, reflexões e contribuições. Desafia os professores a enfrentar novas responsabilidades diante das crises provocadas pela globalização, educar em valores e construir personalidades flexíveis e eticamente desenvolvidas passa a ser fundamental (CASTELLS, 1999), assim como superar propostas de educação baseadas na transmissão de pacotes de conhecimentos sistematizados que proporcionam educação bancária, empobrecedora da formação, da atuação profissional e da participação social (FREIRE,1969).

A despeito do espaço e do tempo, pessoas podem colaborar, reforçar laços de afinidade e se constituírem como comunidades. Qualquer sujeito de qualquer ponto pode não só trocar informações, mas reconstruir significados, rearticular idéias individual e coletivamente, e assim partilhar novos sentidos com todos os usuários da rede, do ciberespaço (SANTOS, 2005, p.18).

O ciberespaço é composto por uma diversidade de elementos constitutivos, interfaces que permitem diversos modos de comunicação: um-um, um-todos e todos-todos em troca simultânea (comunicação síncrona) ou não (comunicação assíncrona) de mensagens. Tais possibilidades podem implicar mudanças diretas, nem melhores nem piores, mas diferentes, na forma e no conteúdo das relações de aprendizagem do coletivo. É através do conjunto de interfaces que os usuários interagem com a máquina e com outros usuários, compondo assim o ciberespaço e a cibercultura.

O ciberespaço é concebido e estruturado de modo a ser, antes de tudo, um espaço social de comunicação e de trabalho em grupo. Portanto, o saber já não é mais o produto pré-construído e "midiaticamen- 
te" difundido, mas o resultado de um trabalho de construção individual ou coletivo a partir de informações ou situações midiaticamente concebidas para oferecer ao aluno ou ao estudante oportunidades de mediação (ALAVA, 2002, p.14).

Como consequência do contexto de redefinição da postura docente, em função da demanda tecnológica, surge a necessidade de preparar professores para atuar, com essas tecnologias, como mediador desse novo processo educativo. Segundo Niskier (2000):

A educação, como um todo, não pode ser operacionalizada sem pessoal competente. Qualquer tentativa de melhoria do sistema pedagógico não prescinde da ação do professor. Em última análise, é ao professor que cabe transformar qualquer nova proposta em uma ação pedagógica competente (NISKIER, 2000, p.26).

$\mathrm{Na}$ identificação e formação desses profissionais, devem ser consideradas as condições intelectuais e humanas necessárias ao desempenho do seu novo papel que é o de orientar os estudos e a aprendizagem dos educandos, ensinando-os a interagir com a coletividade; refletir sobre a práxis e a produção de novos conhecimentos; conceber e realizar novos cursos em função da demanda; organizar pedagógica e didaticamente os conteúdos e adequá-los aos suportes técnicos que produzirão os materiais, definir as bases conceituais para desenvolver propostas pedagógicas sólidas e coerentes com as propostas de Educação a Distância. 


\section{EVOLUÇÃO DA EDUCAÇÃO A DISTÂNCIA}

A EaD não é um fenômeno novo, sendo um modo de ensinar e de aprender individualmente, que existe há, pelo menos, mais de cem anos (MOORE; KEARSLEY, 1996). Antes do aparecimento das comunicações via eletrônica, os educadores usavam a tecnologia impressa e os serviços postais, no que é conhecido como ensino por correspondência.

Com o aproximar do século XXI, revelaram-se alguns eventos que alteraram dramaticamente o cenário do ensino em todo o mundo. A emergência do conhecimento, como um dos fatores mais importantes a ser considerado para a prosperidade econômica das nações, foi um dos raros momentos de mudança, que segundo Toffler (1984) apud Pereira (2008), ocorreu apenas uma vez na história da humanidade, quando da transformação de um sistema econômico baseado na agricultura, para uma economia baseada na indústria. Uma transformação similar ocorre agora, à medida que a economia mundial assenta mais no conhecimento como fundamento para o aumento da produtividade (PRADO; VALENTE, 2002).

Deste modo, segundo Pereira (2008), a emergência da economia do conhecimento teve um duplo efeito no ensino: em primeiro lugar, as tecnologias de informação tiveram um profundo impacto nas práticas de ensino e da aprendizagem, evidenciadas pelo rápido crescimento de universidades virtuais e da expansão de práticas de $\mathrm{EaD}$; em segundo lugar, a indústria e o comércio veem-se a eles próprios como geradores e disseminadores de conhecimento, acabando com o semimonopólio do ensino superior na criação e divulgação de novos conhecimentos. A adoção da EaD conduziu, assim, a uma mudança social maior do que qualquer outro fator. 
A EaD é, tradicionalmente, definida como sendo uma forma de ensinar/aprender, com recurso, o material impresso, ou através de comunicação eletrônica dirigida a indivíduos comprometidos com o processo de aprendizagem, num lugar e num tempo diferentes daqueles em que estão o educador ou educadores. Todavia, a definição tradicional de $\mathrm{EaD}$ tem sofrido modificações, à medida que os desenvolvimentos tecnológicos mais recentes vão criando novos desafios aos educadores, no sentido de (re) conceptualizar a ideia de escola e de aprendizagem ao longo da vida

\section{O ADVENTO DA EDUCAÇÃO ONLINE}

A necessidade de atender à demanda de um novo paradigma educacional que congregasse as transformações advindas da sociedade plural atual, de ordens econômicas, políticas, culturais, científicas e tecnológicas, retomou antigas modalidades de ensino articuladas às novas possibilidades de uma sociedade tecnológica.

Nesta era digital, a sociedade se depara com múltiplas necessidades que se originam das relações entre seres que, imbuídos do desejo de adquirir mais informações e da necessidade de prosseguirem com sua formação "ao longo da vida", buscam caminhos para o fazer pedagógico em ambientes de aprendizagem online.

Nesse contexto, emerge uma série de iniciativas de cursos de especialização, extensão e graduação, pautados nas orientações da legislação vigente, que tem como preocupação básica a construção de novos espaços de aprendizagem via internet. Vale destacar a importância da portaria $n^{0}$ 2.253/2001 que permite as instituições de ensino utilizar um modelo híbrido de ensino nos seus cursos, ampliando os processos interativos nas propostas educacionais. 
As instituições de ensino superior poderão introduzir, na organização pedagógica e curricular de seus cursos superiores reconhecidos, a oferta de disciplinas que, em seu todo ou em parte, utilizem método não presencial, com base no artigo 81 da Lei no 9.394 , de 1996, e no disposto nesta Portaria.

As propostas educativas, que utilizam basicamente os meios telemáticos como a videoconferência, teleconferência e internet, são caracterizadas por Moran (2003) como Educação Online. Para o autor, a educação online permite diferentes desenhos de cursos, desde propostas totalmente virtuais, até perspectivas presenciais, potencializando as dinâmicas da sala de aula convencional.

Em relação à Educação a Distância, ele afirma que “(...) é um conceito mais amplo que o da educação online. Um curso por correspondência é à distância e não é online (...)”(MORAN, 2003, p.40). Este conceito vem sendo ressignificado por diferentes instituições sociais, com destaque às universidades, no sentido de proporcionar cursos de formação, bem como potencializar as discussões na educação presencial. A partir daí, existe uma diversidade de propostas, desde aquelas centradas no docente, e com pouca interação, até aquelas centradas no trabalho em grupo com bastante interatividade.

Moran (2003, p.40) define Educação Online como '(...) o conjunto de ações de ensino-aprendizagem desenvolvidas por meio de meios telemáticos, como a internet, a videoconferência e a teleconferência”.

Outro aspecto que Branco (2003) chama a atenção é em relação à compreensão do que seja Educação a Distância, que vem ampliar as concepções de ensino, antes confinadas à sala de aula. Nesse contexto, podemos reconhecer a importância da criação de comunidades virtuais de aprendizagem no compartilhamento de práticas, conheci- 
mentos, dinamizando a partilha de saberes e o crescimento de todos. A Educação Online se autoeco-organiza pela interatividade dos atores e suas interfaces tecnológicas, por exemplo: um fórum de discussão não se torna fórum sem a partilha de sentidos e os discursos dos seus interlocutores.

Para Santos (2005), além da autoaprendizagem, as interfaces dos ambientes virtuais de aprendizagem (AVA) permitem a interatividade e a aprendizagem colaborativa, ou seja, além de aprender com o material, o participante aprende na dialógica com outros sujeitos envolvidos - professores, tutores e principalmente outros cursistas - através de processos de comunicação síncronos e assíncronos (fórum de discussão, lista, chats, blogs, webfólios entre outros). Isso é revolucionário, inclusive quebra e transforma o conceito de distância.

Em educação online é importante garantir tanto atividades individuais quanto colaborativas e cooperativas. É preciso garantir aos sujeitos envolvidos vivências e diversos desafios sociocognitivos e político-culturais ao ato de pesquisar.

Dentre as diversas possibilidades abertas pelo paradigma digital, ocorre a liberação do polo da emissão que veio intensificar as várias relações sociais. Exemplo disso são os blogs, os chats, os fóruns de discussão, os e-mails, que potencializam a comunicação cada vez mais de forma interativa. Ressalta-se também a importância da conexão, que une os homens entre si através da máquina, numa constante troca de informações.

Contribuindo com a discussão sobre a Educação Online, Almeida (2003) reforça o seu uso via a internet, e a caracteriza como uma modalidade de educação, cuja comunicação ocorre de forma síncrona e assíncrona. Ressalta a autora que as interações entre os participantes podem ocorrer a partir de diferentes perspectivas comuni- 
cacionais, quais sejam: comunicação um-a-um, comunicação de umtodos e comunicação todos-todos. A terceira perspectiva traz como desafio a superação de propostas educativas hierárquicas e lineares, incluindo o debate plural de ideias e a possibilidade de intervenção e alteração na mensagem.

Almeida (2003, p.333) salienta que, na EaD em meio digital, pode-se observar que existe um foco central em determinado aspecto, diretamente relacionado com a abordagem educacional implícita, o qual pode ser:

- O material instrucional disponibilizado, cuja abordagem está centrada na informação fornecida por um tutorial ou livro eletrônico hipermediático. Essa abordagem se assemelha à autoinstrução e distribuição de materiais, chegando a dispensar a figura do professor;

- O professor, considerado o centro do processo educacional, o que indica abordagem centrada na instrução fornecida pelo professor, que recebe distintas denominações de acordo com a proposta do curso;

- O aluno, que aprende por si mesmo, em contato com os objetos disponibilizados no ambiente, realizando as atividades propostas a seu tempo e de seu espaço;

- As relações que podem se estabelecer entre todos os participantes evidenciando um processo educacional colaborativo no qual todos se comunicam com todos e podem produzir conhecimento, como ocorre nas comunidades virtuais colaborativas.

Para Santos (2005), o conceito de educação online está diretamente ligado ao desenvolvimento da cibercultura por possibilitar: a convergência de mídias, os encontros entre diferentes pessoas afastadas geograficamente, a vivência da interatividade, a aprendizagem colaborativa e os processos de comunicação síncronos e assíncronos. 
Para essa autora, todo esse potencial da educação online diferenciase das práticas convencionais de $\mathrm{EaD}$, que têm como foco principal a autoaprendizagem. A autora ressalta que essa perspectiva é reducionista, por não propiciar a dialógica entre os sujeitos, centrando-se apenas na resolução de atividades propostas no material do curso e a posterior entrega ao professor-tutor.

O grande desafio da Educação Online não está centrado unicamente na disponibilização de ambientes e interfaces gratuitas para a sua utilização nos diferentes espaços educativos, e sim na compreensão desses artefatos como potencializadores de práticas pedagógicas inovadoras que permitam aos aprendizes interações e coautoria na construção do conhecimento e do seu próprio processo de aprendizagem (SANTOS, 2005).

Cada vez mais sujeitos e grupos-sujeitos, empresas, organizações, enfim, espaços multirreferenciais de aprendizagem vêm lançando mão do conceito de Educação Online e promovendo a difusão cultural de suas ideias, potencializando a democratização da informação, da comunicação e da aprendizagem entre indivíduos geograficamente dispersos seja como elemento potencializador da educação presencial e ou da Educação a Distância. Os meios telemáticos mais utilizados nas atuais práticas de educação online são os ambientes virtuais de aprendizagem disponibilizados no ciberespaço.

\section{METODOLOGIA}

O conhecimento é algo que se constrói a partir das experiências vividas, o aprendizado resultante das dificuldades e das conquistas observadas no cotidiano. Para que esse conhecimento esteja acoplado às necessidades e demandas sociais torna-se indispensável a 
avaliação permanente e criativa do processo educacional e seus agentes transformadores, daí a importância da pesquisa, como aponta Demo:

\begin{abstract}
A aventura de construir conhecimento é tipicamente a aventura dos tempos modernos, num conluio surpreendente entre inteligência crítica e criativa humana e meios eletrônicos socializadores. Pesquisa adquire, assim, a condição de função básica do sistema educacional, em termos instrumentais, pervadindo não só as técnicas construtivas de conhecimento, mas igualmente o impulso crítico e criativo da educação emancipatória (DEMO, 1994, p.16).
\end{abstract}

Levando em conta a complexidade que envolve o fenômeno educacional, foi feita a opção pela Abordagem Qualitativa, por ser uma forma adequada para entender a natureza de um fenômeno social. "Os estudos que empregam uma metodologia qualitativa podem descrever a complexidade de determinado problema, analisar a interação de certas variáveis"(RICHARDSON, 1999, p.80).

Considerando os objetivos da nossa investigação, realizamos uma Pesquisa Exploratória que nos proporcionou maior familiaridade com o tema, a partir do levantamento bibliográfico que "é a base para as demais pesquisas e pode-se dizer que é uma constante na vida de quem se propõe a estudar”(FACHIN, 2001, p.125).

Sabe-se que a pesquisa bibliográfica é composta por mais de um momento, pois exige a localização dos exemplares a serem analisados, sua leitura e fichamento. Neste processo, foram classificados livros, dissertações, teses e artigos com temáticas relacionadas ao objeto de estudo. 


\section{FORMAÇÃO DE PROFESSORES UNIVERSITÁRIOS PARA EDUCAÇÃO ONLINE}

As transformações acarretadas pela rápida obsolescência da informação fazem com que as pessoas busquem uma formação permanente, uma atualização constante.

Para se implantar a EaD nas instituições educativas em nosso país, há que se rever a formação dos professores, para prepará -los ao desempenho das funções exigidas nesta modalidade de ensino. Exigindo, assim, constante atualização, ou seja, investimento permanente no processo de educação continuada para delinear o perfil necessário às exigências de sua formação profissional.

Deve-se assegurar, nos cursos de EaD, uma dupla qualidade, pedagógica e técnica, ou seja, um modelo mais integrado onde o professor deverá ser capaz de acompanhar e orientar todas as fases da produção. O uso mais intensivo dos meios tecnológicos de informação e comunicação torna o ensino mais complexo e exige a segmentação do ato de ensinar em múltiplas tarefas, sendo esta segmentação a característica principal da EaD.

É notório que o professor necessita se adaptar às novas exigências, precisa rever seus procedimentos e até mesmo a sua maneira de ensinar, aprender, pesquisar, analisar a ciência e de encarar a vida. Deverá assumir um papel de organizar, administrar e regular situação de aprendizagens, deixando de ser o dono do saber e o controlador da aprendizagem, para ser um mediador que estimula a curiosidade, o debate e a interação com os outros participantes do processo. No âmbito desta transição paradigmática, o professor desafia, orienta e acompanha o percurso e o resultado dos estudos, investigações e elaborações desenvolvidas pelo aluno, individual e coletivamente, pas- 
sando assim a construir ao invés de reproduzir, juntamente com os alunos, o conhecimento.

Espera-se que as decisões docentes promovam participação ativa, compartilhada e cooperativa; criem oportunidades variadas e flexíveis de negociação e construção de conhecimentos em ambientes presenciais e virtuais; utilizem um olhar prático-teórico aliado à força pedagógica da reflexão e observação da própria prática docente; exercitem metacognição e empatia nas tentativas de compreensão das necessidades de aprendizagem, facilidades, dificuldades e de modos de superá-las (FIORENTINI, 2009, p.137).

Para fazer frente a estas novas formas de ensinar, o professor passará a ter a necessidade constante de atualização, tanto no que se refere ao seu conteúdo de ensino, quanto em relação às novas metodologias de ensino e às novas tecnologias.

É fundamental levar os professores a se apropriarem criticamente dessas tecnologias, descobrindo as possibilidades de utilização que elas colocam à disposição da aprendizagem do aluno, favorecendo dessa forma o repensar do próprio ato de ensinar.

O documento criado pelo MEC, que aponta os Indicadores de Qualidade para cursos de graduação a distância, destaca que a instituição deve contar com educadores capazes de:

a) Estabelecer os fundamentos teóricos do projeto;

b) Selecionar e preparar todo o conteúdo curricular articulado a procedimentos e atividades pedagógicas;

c) Identificar os objetivos referentes a competências cognitivas, habilidades e atitudes;

d) Definir bibliografia, videografia, iconografia, audiografia etc., básicas e complementares;

e) Elaborar textos para programas a distância;

f) Apreciar avaliativamente o material didático antes e depois de ser impresso, videogravado, au- 
diogravado, etc., indicando correções e aperfeiçoamentos;

g) Motivar, orientar, acompanhar e avaliar os alunos;

h) Auto-avaliar-se continuamente como profissional participante do coletivo de um projeto de graduação a distância (BRASIL/MEC, 2000, p.06).

Segundo Moran (2001), o desafio que os profissionais que atuam no ensino superior irão enfrentar é motivar os estudantes, fase em que os alunos não precisam ir todos os dias à aula, a continuar aprendendo quando não estão em sala de aula. Educar a distância significa uma forma de ensino-aprendizagem onde ocorram trocas e não somente repasse de informação, que não deve ser simplesmente o ato de colocar conteúdo em uma página e depois cobrar atividade dos alunos. Estimular o aluno a aprender em ambientes virtuais é outro grande desafio pedagógico.

Ensinar em ambientes digitais e interativos de aprendizagem significa: organizar situações de aprendizagem, planejar e propor atividades; disponibilizar materiais de apoio com o uso de múltiplas mídias e linguagens; ter um professor que atue como mediador e orientador do aluno, procurando identificar suas representações de pensamento; fornecer informações relevantes, incentivar a busca de distintas fontes de informações e a realização de experimentações; provocar a reflexão sobre processos e produtos; favorecer a formalização de conceitos; propiciar a interaprendizagem e a aprendizagem significativa do aluno.

Nóvoa (2010) enuncia cinco teses a serem consideradas na formação de professores: conhecimento que se desenvolve a partir da prática voltada à aprendizagem; cultura profissional criada "dentro" da profissão, ou seja, aprendendo com os mais experientes; tato pedagógico que integra as distintas dimensões pessoais e as relações comu- 
nicativas com a profissão; trabalho em equipe e exercício coletivo no desenvolvimento do projeto pedagógico da escola; compromisso social que engloba os princípios e valores da inclusão social, da convivência com a diversidade cultural e da participação ativa na sociedade.

Ao trazer essas teses para a EaD online e inserir no bojo da formação do professor as TDIC, é importante considerar que o uso dessas tecnologias na formação envolve praticamente os mesmos elementos que qualquer processo formativo a distância (professores, alunos, estratégias didáticas, conteúdo, sistema de avaliação, etc.) e se diferencia na gestão desses elementos e na exploração das possibilidades pedagógicas das tecnologias de suporte, constituindo a EaD online como uma nova modalidade formativa (CASAMAYOR, 2008).

Trata-se de uma formação na práxis, que associa situações de formação e de trabalho por meio de um exercício reflexivo rigoroso, com o intuito de provocar a tomada de consciência sobre o processo de reculturação, reestruturação e reorganização temporal da prática (FULLAN, 1996 apud ALMEIDA, 2010). Essa formação não é simples, especialmente quando se trata de formação contínua de professores voltada para sua atuação em novos espaços, tempos e culturas, como é o caso da formação online integrada com a atuação na EaD online, a qual tem como norte as mudanças nas concepções, nos valores, nas crenças e nas práticas, que permitem ao professor formando mergulhar na nova cultura, reestruturar o pensamento de acordo com os novos modos de expressá-lo, interagir, construir conhecimento, trabalhar em colaboração e reorganizar o próprio tempo.

Dado que a formação do professor em ambiente online tem como finalidade prepará-lo para realizar o trabalho pedagógico mediatizado pelas linguagens veiculadas pelas TDIC, os conceitos de reculturação, reestruturação e reorganização dizem respeito à forma- 
ção em ambiente online, na qual o professor formando assuma diferentes papéis: no início de aluno, em seguida de planejador/designer de atividades online, seguido de mediador da aprendizagem do aluno em situação de ensino e aprendizagem online e de avaliador desses diferentes papéis.

A reflexão na ação e sobre a ação (SHÖN, 1992) deve permear todo o processo formativo e fornecer as bases para que o próprio formando possa compreender as mudanças nas suas concepções relacionadas ao aprender, planejar, ensinar e se comunicar em ambiente online. Porém, a reflexão não acontece ao acaso, ocorre quando são criadas condições com a intenção de provocar a introspecção, o olhar para as próprias representações, sentidos e valores que o professor atribui à sua experiência e à experiência do outro, em busca de compreender criticamente essa ação e propor transformações para a realização de novas ações mais apropriadas ao contexto de aprendizagem de seus alunos.

A análise dos caminhos epistemológicos percorridos pelo formando em seu processo de aprendizagem e o desenvolvimento de produções e dos registros digitais das interações favorecem ao professor em formação o reconhecimento das descrições, justificativas e explicações sobre as próprias experiências e possibilitam colocar em discussão os possíveis conflitos, contradições ou interpretações equivocadas, problematizá-los, refletir criticamente sobre eles e negociar novos significados. 


\section{CONSIDERAÇÕES FINAIS}

É fundamental levar os professores a se apropriarem criticamente dessas tecnologias, descobrindo as possibilidades de utilização que elas colocam à disposição da aprendizagem do aluno, favorecendo, dessa forma, o repensar do próprio ato de ensinar.

O trabalho docente online envolve o domínio do conteúdo de estudo, das tecnologias em uso e do processo pedagógico, no que se refere às concepções teóricas e metodológicas; a criação de estratégias didáticas que proporcionem a aprendizagem; a articulação do conteúdo com a tecnologia no desenvolvimento das atividades; a atitude de questionamento, diálogo, produção de conhecimento, colaboração e reflexão sobre a própria atuação; e a capacidade para trabalhar em grupo.

A formação docente online deve criar condições para que o professor possa desenvolver o domínio dessas tecnologias ao ponto de explorar confortavelmente suas funcionalidades e modos de operação para identificar suas contribuições pedagógicas para a interação multidirecional à autonomia do aluno na busca de informações, na regulação do tempo, no ritmo de estudo; acompanhar o caminho epistemológico do aluno, o trabalho em grupo colaborativo, os estudos de caso; ampliar o universo cultural do aprendiz; e provocar a transformação da prática pedagógica. Isso exige a superação de concepções de formação centradas no domínio de recursos e tecnologias ou na análise teórica sobre as tecnologias na sociedade e na educação e volta-se para a integração entre esses dois polos associados com a experiência em contexto online e com a reflexão sobre essa prática à luz de teorias que são articuladas com as experiências. 


\section{REFERÊNCIAS}

ALAVA, S. Ciberespaço e formações abertas: rumo a novas práticas educacionais. Porto Alegre: Artmed, 2002.

ALMEIDA, M. E. B. Educação a distância na internet: abordagens e contribuições dos ambientes digitais de aprendizagem. Educação e Pesquisa. In Revista da Faculdade de Educação da USP. São Paulo, v.29, n.2, 178p., jul./dez, 2003.

BEHAR, P. A. (Org.). Modelos pedagógicos em educação a distância. Porto Alegre: Artmed, 2009.

BELLONI, M. L. (org.). A formação na sociedade do espetáculo. São Paulo: Loyola, 2002.

BRANCO, A. C. A portaria no 2.253/2001 no contexto da evolução da educação a distância nas instituições de ensino superior do Brasil. In: SILVA, M. (Org.). Educação Online: teorias, práticas, legislação e formação corporativa. São Paulo: Loyola, 2003.

BRASIL. Indicadores de qualidade para cursos de graduação a distância. Brasília: MEC / Secretaria de Educação a Distância, 2000. Disponível em: http://www.mec.gov.br/seed/indicadores.shtm. Acesso em: 20 out. 2010.

Lei n. 9.394, de 20 de dezembro de 1996. Brasília: Presidência da República. Disponível em: http·//www.mec.gov.br/seed/ tvescola/ftp/leis/lein9394.doc. Acesso em: 20 out. 2010. 
CASTELLS, M. A sociedade em rede. São Paulo: Paz e Terra, 1999.

DEMO, P. Pesquisa e construção de conhecimento: metodologia científica no caminho de Habermas. Rio de Janeiro: Tempo Brasileiro, 1994.

FACHIN, O. Fundamentos de metodologia. 3. ed. São Paulo: Saraiva, 2001.

FIORENTINI, L. M. R. Aprender e ensinar com tecnologias, a distância e /ou em ambiente virtual de aprendizagem. In. Educação superior a distância: Comunidade de Trabalho e Aprendizagem em Rede (CTAR). Org. Souza, A. M. et al. Brasília: Universidade de Brasília, Faculdade de Educação, 2009.

FREIRE, P. Pedagogia da autonomia: saberes necessários à prática educativa. 15. ed. São Paulo: Paz e Terra, 1996. (Coleção Leitura)

GIL, A. C. Como elaborar projetos de pesquisa. São Paulo: Atlas, 1991.

GIL, A. C. Como elaborar projetos de pesquisa. 3. ed. São Paulo: Atlas, 1991.

LEVY, P. Cibercultura. Rio de Janeiro: Editora 34, 1999.

MOORE, M.; KEARSLEY, G. Educação a distância: uma visão integrada. São Paulo: Thomson Learning, 2007. 
MORAN, J. M. Contribuições para uma pedagogia da educação online. In. SILVA, M. (org.). Educação online: teorias, legislação, formação corporativa. São Paulo: Loyola, 2003.

NISKIER, A. Educação à distância: a tecnologia da esperança. 2. ed. São Paulo: Loyola, 2000.

NÓVOA, A. Profissão docente. In: Revista Educação, n. 154, fev. São Paulo, 2010. Disponível em: http://revistaeducacao.uol.com.br/textos.asp?codigo=12841. Acesso em: 10 nov. 2010 .

PEREIRA, E. W. Educação a distância, concepção e desenvolvimento. In.: Revista Linhas Críticas, v.9, n.17, p.197-212, jul/ dez. Brasília, 2003. Disponível em: http://www.fe.unb.br/linhascriticas/n17/educacao_a_distancia.html. Acesso em: 25 nov. 2010.

PORTO, M. Nova realidade digital tem reflexos nas relações de trabalho. Projeto Ponto-Futuro. Disponível em: http·//www.pontofuturo.org/home/modules.php. Acesso em: 07 out. 2010.

POZO, J. I. A sociedade da aprendizagem e o desafio de converter informação em conhecimento. In.: Pátio Revista Pedagógica, n.31, p.8-11, ago/out 2004.

PRADO, M. E. B. B.; VALENTE, J. A. A educação a distância possibilitando a formação do professor com base no ciclo da prática pedagógica. In: MORAES, M. C. Educação a distância: fundamentos e práticas. Campinas: SP, 2002. 
RICHARDSON, R. J. (Org.) Pesquisa social: métodos e técnicas. São Paulo: Atlas, 1999.

SANTOS, C. A. A expansão da educação superior rumo à expansão do capital: interfaces com a educação a distância. Tese (Doutorado). Universidade de São Paulo, 2008. Disponível em: www.teses.usp.br/ teses/disponiveis/48/.../TeseCatarinaAlmeidaSantos.pdf Acesso em: 27 mar. 2010.

SCHÖN, D. Formar professores como profissionais reflexivos. In: NÓVOA, A. (Coord.). Os professores e sua formação. Lisboa: Dom Quixote, 1992.

SILVA, M. Tecnologias e materiais didáticos nos cursos superiores a distância: promovendo a aprendizagem por meio da interatividade. In: Boletim do Salto para o Futuro. PGM 4 - Texto 1, 2003. (Série Educação a Distância na Universidade do Século XXI). Disponível em: http·/www.tvebrasil.com.br/SALTO/boletins2003/ edu/tetxt4. htm. Acesso em: 18 nov. 2010.

VALENTE, V. R. M. A formação de professores para o uso das tecnologias da informação e comunicação no processo pedagógico: caminhos percorridos pelo Núcleo de Educação e Tecnologias da rede municipal de ensino de Salvador. Dissertação - (Mestrado do Programa de Pós-Graduação em Educação e Contemporaneidade). Salvador: Universidade do Estado da Bahia, 2005. 


\title{
REDES SOCIAIS NO PROCESSO DE
}

\section{ENSINO E APRENDIZAGEM: COM A PALAVRA O ADOLESCENTE}

\author{
Francineide Sales da Silva \\ Maria Lúcia Serafim
}

\section{INTRODUÇÃO}

Vive-se numa sociedade de constantes transformações e a internet é responsável por grandes mudanças, no mundo atual, contribuindo positivamente em diversos setores da nossa sociedade. Sendo utilizada por vários setores da sociedade como escolas, faculdades, empresas e diversos locais, possibilitando acesso às informações e notícias do mundo em apenas um click.

Em 2006, surgiram as redes sociais e o Orkut tornou-se o preferido dos internautas. Logo depois, outras redes sociais como, por exemplo, o Facebook, Blog e o Twitter. Essas Redes Sociais fazem parte do cotidiano da maioria dos usuários da internet e são utilizadas para vários fins como: obtenção do perfil de um usuário por revelar traços de comportamento e isso é aproveitado até para uma seleção de emprego, para interesses pessoais, formação de grupos de estudo, como também descoberta de novos amigos ou novas informações sobre determinado assunto. 
Além do mais, as redes sociais são inteligentes e democráticas, pois as pessoas expõem suas preferências, facilitando o trabalho das empresas, quando realizam ações voltadas para seu público-alvo, na criação de novos produtos ou quando se decide trabalhar mais em um determinado produto para atender o público de maneira satisfatória de acordo com suas preferências.

As redes sociais também estão cada vez mais presentes no dia a dia de alunos e professores, no entanto, essas ferramentas ainda não são muito exploradas em sala de aula. $\mathrm{Na}$ maioria dos casos, as escolas não permitem o acesso a esse tipo de rede social em função do "medo"de que o aluno se interesse por assuntos que não estejam diretamente ligados aos estudos de sala de aula.

Este texto é um estudo sobre 'Redes sociais no processo de ensino e aprendizagem: com a palavra os adolescentes", e traz reflexões em torno do melhor aproveitamento destes espaços virtuais no processo de ensino e aprendizagem dos adolescentes, pois estes são o que se pode evidenciar como geração interativa. É fruto de estudo monográfico, sendo de natureza qualitativa exploratória, e os dados foram coletados através de um questionário semiestruturado em duas escolas, uma da rede pública Escola Estadual de Ensino Fundamental e Médio Senador Humberto Lucena e outra da rede privada Espaço Educacional Carmela Veloso no Município de Campina Grande-PB. A pesquisa ocorreu nos meses de agosto e setembro de 2010. Os respondentes do estudo foram 18 alunos da escola pública e 30 da escola particular que cursam o $1^{\circ}$ ano do ensino médio. A faixa etária dos adolescentes está entre 14 e 17 anos de idades.

O objetivo geral do estudo foi o de buscar, através da fala dos adolescentes, como está se constituindo a relação destes com as redes sociais da internet, tendo em vista as implicações desta relação 
para o processo de ensino e aprendizagem. E como específicos: dar voz a geração interativa sobre o uso das redes sociais na escola e verificar se as redes sociais do ciberespaço formado a partir de sites de relacionamentos favorecem as relações de ensino e aprendizagem entre aluno e professor.

Acredita-se na possibilidade de que as redes sociais do ciberespaço possam vir a favorecer a interação e socialização dos processos desenvolvidos na escola. E podem contribuir significativamente com o trabalho do professor quando utilizadas de forma pedagógica.

\section{AS TECNOLOGIAS NA SOCIEDADE DA INFORMAÇÃO}

A sociedade atual está vivendo um processo de profundas mudanças em que as tecnologias são as principais responsáveis. Alguns autores já consideram isto um novo paradigma da sociedade e denominam como Sociedade da Informação ${ }^{1}$. Essa nova sociedade baseia-se no conhecimento e encontra-se em processo de formação e expansão por todo o mundo, desempenhando um papel importante e fundamental na produção de riquezas e na contribuição para o bem -estar e qualidade de vida dos cidadãos.

A crescente evolução das tecnologias de informação e comunicação vem criando um novo contexto virtual e, sobretudo, novas maneiras de interagir no espaço cibernético. A internet é responsável por grandes transformações sociais e culturais e tornou-se indispensável para a sociedade, pois atualmente $80 \%$ da população têm acesso a ela, que é considerada um importante canal mundial de

1 Sociedade da informação é um termo que também pode ser chamado de Sociedade do Conhecimento, surgiu no fim do Século XX, vinda da expressão Globalização. 
distribuição de bens, serviços e empregos provocando grandes mudanças na economia, nos mercados e nas indústrias, além de influenciar no comportamento dos consumidores; nos mercados de trabalho e de emprego, pois existem inúmeras oportunidades que podem ser exploradas como conhecer lugares virtualmente, fazer cursos a distância, trabalhar pela internet, conhecer empresas e pessoas, etc.

Para Moran (1994), a internet também está começando a provocar mudanças profundas na educação. As tecnologias permitem um novo encantamento na escola, possibilitam que alunos conversem e pesquisem com outros alunos da mesma cidade, país ou do exterior, no seu próprio ritmo. E numa sociedade que se desenvolve, de modo célere, as possibilidades tecnológicas estão se tornando acessíveis e os alunos de hoje em dia estão mais "antenados" com essas tecnologias versáteis.

É o que aponta a educadora Bencini (2002), quando se refere à Era da Informação como um fato consumado e que, a cada dia, os alunos estão mais conectados, mas precisam da ajuda do educador para aprender a interpretar, pois adepto ou não às inovações tecnológicas, os professores devem reconhecer que, graças a ela, a informação não é mais privilégio de poucos, e o que vale não é apenas possuí-las, mas interpretá-las, em outras palavras, transformar informação em conhecimento. Não basta possuir uma infraestrutura moderna de comunicação; é preciso capacidade para converter informação em conhecimento. Assim ressalta Alarcão (2003):

Eu diria que, primeiro que tudo, os professores têm que repensar o seu papel. Se é certo que continuam a ser fontes de informação, têm de se consciencializar que são apenas uma fonte de informação, entre muitas outras. Deve, no entanto, salientar-se que o seu valor informativo tem níveis diferentes conforme o acesso que os seus alunos puderem ter 
a outras fontes de informação. É fundamental que os professores percebam esta diversidade. Haverá alunos que não vão precisar muito da informação substantiva dos professores, embora precisem da informação processual no sentido de a digerirem e criticarem (ALARCÃO, 2003, p.31).

É evidente o papel fundamental do professor na sociedade da informação, a necessidade de inovar e acompanhar essas tecnologias para não ficar ultrapassado, pois a tecnologia na educação requer um olhar mais abrangente, envolvendo novas formas de ensinar e de aprender condizentes com o modelo da sociedade do conhecimento, o qual se caracteriza pelos princípios da diversidade, da integração e da complexidade.

\section{AS TECNOLOGIAS DA INFORMAÇÃO E DA COMUNICAÇÃO NA EDUCAÇÃO E PRÁTICA DOCENTE}

A cada dia, as tecnologias se afirmam nos diversos segmentos sociais, induzindo pesquisadores a considerar a proliferação de computadores e de toda uma postura baseada na cultura da informática como pressuposto para a identificação de um novo modelo de sociedade, definida como digital.

Em cada ambiente, a sua ausência é expressão de atraso. Uma pessoa que não possui um conhecimento básico sobre informática é vista como sendo subdesenvolvido, um indivíduo atrasado, quer social, quer profissionalmente. Quem o possui, por outro lado, parece predisposto a enfrentar com tranquilidade qualquer situação. 
Os meios digitais têm um enorme potencial para o ensino, mas é difícil realizar esse potencial se eles são considerados apenas tecnologias e não formas de cultura e comunicação.

Percebe-se que as preocupações existem, mas não contemplam o problema completamente. Os equívocos em relação ao uso do computador no ambiente escolar são diversos; podemos dizer que são de ordem estrutural, social, econômica e pedagógica. É certo que as tecnologias digitais são inevitáveis na vida moderna, não há como ignorá-las, nem tampouco impedir o acesso, a interação dos alunos aos recursos midiáticos; o que nos falta é instrução e preparo para lidar com tais recursos, e entender que a tecnologia por si só não faz milagres, nem interfere na aprendizagem dos educandos de forma positiva.

Essa nova relação é um grande desafio para a escola, já que as informações disponíveis na Internet são muito maiores do que as que se tem acesso a partir dos professores na sala de aula. A escola entendida como espaço de produção e transmissão do conhecimento precisa abrir-se às novas e diferentes formas de comunicação. Essa afirmação parte da necessidade da inserção positiva da tecnologia na sala de aula e na vida de professores e alunos.

Dias e Guimarães (2006) destacam que uma educação comprometida com o desenvolvimento e a construção de conhecimentos não pode restringir-se a oferecer caminhos únicos ancorados em currículos áridos e enciclopédicos, desvinculados de contextos significativos para o aluno. E numa sociedade dita da informação e do conhecimento a escola não pode ficar a reboque das transformações que estão sendo possibilitadas pelas tecnologias digitais.

O fazer educativo deve ser pautado também na contemporaneidade. Não se defende aqui o total abandono do processo tradicio- 
nal, do "novo" em detrimento do "velho", no entanto, é preciso enfatizar que os métodos de ensino e os recursos metodológicos utilizados na sala de aula, merecem ser revistos em função de novos ambientes de aprendizagem e do perfil de aluno que ora se configura numa sociedade que aprende e se desenvolve.

Demo (2009) diz que não há mais como procurar subterfúgios para retardar essa cooperação entre tecnologias e educação. As tecnologias, não podem ignorar a pedagogia, ou enfurecer-se com o seu atraso, porque a parceria parece inevitável, além de desejável. A pedagogia tecnologicamente correta teria a pretensão de estabelecer com as novas tecnologias a cooperação marcada pela reciprocidade respeitosa e produtiva.

Pode-se dizer que a pedagogia se encontra em processo de apropriação da tecnologia, principalmente no que diz respeito ao uso do computador e da internet, ainda não estamos tecnologicamente corretos. Alguns equívocos colaboram para o distanciamento entre a tecnologia da comunicação e informação e a escola. A distância aqui entendida como afastamento dos objetivos propostos para tecnologia - o computador/internet - na educação. Não se trata apenas de uma distância física, material, mas de conhecimento, de um saber pedagógico.

Referenda-se que as tecnologias não substituem o professor, porém podem possibilitar mudanças em sua metodologia. O Professor assume uma nova postura para poder acompanhar todo esse avanço, transforma-se agora no estimulador da curiosidade do aluno por querer conhecer, desenvolvendo o papel de mediador pedagógico facilitando e motivando a aprendizagem do aluno, como orienta Silva: 
É preciso enfatizar: o essencial não é a tecnologia, mas um novo estilo de pedagogia sustentado por uma modalidade comunicacional que supõe interatividade, isto é, participação, cooperação, bidirecionalidade e multiplicidade de conexões entre informações e atores envolvidos. Mais do que nunca o professor está desafiado a modificar sua comunicação em sala de aula e na educação. Isso significa modificar sua autoria enquanto docente e inventar um novo modelo de educação (SILVA, 2000, p.15).

O educador precisa buscar alternativas de dinamizar suas aulas, e principalmente capacitar-se, para que este possa explorar mais e com qualidade os recursos advindos das Tecnologias de Informação e Comunicação (TICs). É visível a dificuldade que muitos professores têm em acompanhar essa nova pedagogia tecnológica, enquanto os alunos as usam e dominam. É preciso encantar os jovens, convencê -los com bons argumentos. O professor é essencial e uma de suas funções mais importantes é o seu olhar crítico sobre a tecnologia, ele tem que mergulhar no mundo tecnológico, porque só se pode questionar o que se conhece por dentro.

O professor aparece nesse cenário como elo fundamental entre a tecnologia e o aprendiz/educando, porém sentimos uma grande resistência dos mesmos em aceitar as novas ferramentas de ensino e aprendizagem. A falta de formação adequada para lidar com aparatos tecnológicos no cotidiano escolar, a preferência por continuar acreditando em uma teoria única - na tradição instrucionalista do argumento da autoridade - explica parte do desapreço deles em relação aos meios tecnológicos, porém não justifica o não reconhecimento da sua importância no cotidiano da escola.

Ainda nesta linha de pensamento, Porto (2006) lembra que a maioria dos docentes se vê apenas como usuário/telespectador dian- 
te das TIC. A preparação social, e/ou pedagógica para seu uso não é, na maioria das vezes, cogitada.

A tecnologia introduz mudanças, para as quais o professor precisa preparar-se, pela razão fundante de que é essencial que entre nesse processo como sujeito, não como objeto arrastado, tragado. A consciência de que é preciso desconstruir saberes normatizados, impostos ao longo do tempo, que determinaram a postura do professor apenas como transmissor de conhecimentos, "o sabe tudo", é fundamental para a construção de novos saberes, novas posturas, de olhares inquietos sobre o novo.

Para transformar este cenário, deve-se tomar conhecimento destas novas necessidades e assim trazer soluções para a prática educacional, adequando-se às diferentes realidades das escolas, pois as tecnologias não se estabelecem sozinhas, elas se apoiam e promovem resultados através de seus idealizadores.

Para Moran (2007), a modificação na educação, depende de alguns fatores: em primeiro lugar, termos professores maduros intelectual e emocionalmente, pessoas curiosas, entusiasmadas, abertas que saibam motivar e dialogar. Ressalta, ainda, que o educador autêntico é humilde e confiante. Mostra o que sabe e, ao mesmo tempo, está atento ao que não sabe, ao novo.

Já Masetto (2009) reforça a ideia de que o professor precisa assumir uma nova postura diante das inovações tecnológicas. Embora, vez por outra, ainda desempenhe o papel do especialista que possui conhecimento e/ou experiências a comunicar, no mais das vezes desempenhará o papel de orientador das atividades do aluno, de consultor, de facilitador da aprendizagem, de alguém que pode colaborar para dinamizar a aprendizagem do aluno, desempenhará o papel de 
quem trabalha em equipe, junto com o aluno buscando os mesmos objetivos; enfim desenvolverá o papel de mediador pedagógico.

Entretanto, o processo de modificação não depende apenas de professores e alunos, mas também de termos administradores, diretores e coordenadores mais abertos, que entendam todas as dimensões que estão envolvidas no processo pedagógico, além das empresariais ligadas ao lucro; que apoiem os professores inovadores, que equilibrem o gerenciamento empresarial, tecnológico e o humano, contribuindo para que haja um ambiente de maior inovação, intercâmbio e comunicação. Segundo Valente:

As práticas pedagógicas inovadoras acontecem quando as instituições se propõem a repensar e a transformar a sua estrutura cristalizada em uma estrutura flexível, dinâmica e articuladora. No entanto, como isto pode ser possível em projetos de grande dimensão que atingem todo um país ou, por outro lado, em escolas isoladas? A possibilidade de sucesso está em se considerar os professores não apenas como os executores do projeto, responsáveis pela utilização dos computadores e consumidores dos materiais e programas escolhidos pelos idealizadores do projeto, mas principalmente como parceiros na concepção de todo o trabalho. Além disso, os professores devem ser formados adequadamente para poderem desenvolver e avaliar os resultados desses projetos (VALENTE, 1998, p.17).

É importante fazer uso do potencial educativo das tecnologias da informação e da comunicação, pois sem o suporte tecnológico, ficam comprometidas as chances de aumentar a variedade e a diversidade necessárias à sala de aula contemporânea, pois o valor da tecnologia não está nela e em si mesmo, mas depende do uso que dela fazemos. 
Comunga-se com a ideia de que variedade e diversidade de aparatos tecnológicos - desde o uso de transparências, apresentações em quadro-negro ou Power Point até a internet - na sala de aula, não garantem mudanças significativas no contexto educacional. Pois, na maioria das vezes, por meio desses recursos são reproduzidas as mesmas atitudes, o mesmo paradigma educacional pelo qual fomos formados.

Então, entende-se que o saber pedagógico, aquele referente ao uso, à finalidade, deve permear todo processo de articulação entre tecnologia e educação. Pois como já foi dito, atualmente não se concebe pensar em sociedade sem a presença da tecnologia, e a escola deve anunciar e fazer uso desses novos paradigmas corretamente, com intuito de promover à autonomia, a inclusão, a disseminação de várias formas de ensinar e aprender.

Assim, as tecnologias de informação e/ou comunicação possibilitam ao indivíduo ter acesso a uma ampla gama de informações e complexidades de um contexto (próximo ou distante) que, num processo educativo, pode servir como elemento de aprendizagem, como espaço de socialização, gerando saberes e conhecimentos científicos.

Neste contexto, Porto (2006) faz algumas observações sobre o potencial educativo que a tecnologia pode proporcionar no que diz respeito à rapidez, recepção individualizada, interatividade e participação, hipertextualidade, realidade virtual e digitalização/ideologia, como recursos que vêm para somar no processo de ensino e aprendizagem.

A rapidez com que as informações são processadas, como chega ao indivíduo em tempo real, muda a forma de ler, de interpretar, de aprender já existente. A forma de apreender o mundo muda principalmente para os jovens, que hoje conectados buscam o conhecimento através das múltiplas linguagens e sentidos que a tecnologia oferece. 


\section{AS REDES SOCIAIS NO CIBERESPAÇO}

Na sociedade da informação, é preciso reaprender a conhecer e ensinar, com o desenvolvimento das tecnologias digitais e o crescimento das redes interativas, essas novas maneiras de acesso aos saberes, de construir o conhecimento, de comunicar-se e de manter relações sociais estão, cada vez mais, dependentes desse espaço de comunicação: o ciberespaço, que Lévy (2009, p.92) define como "o espaço de comunicação aberto pela interconexão mundial dos computadores e das memórias dos computadores".

Os meios de aprendizagem colaborativa nascem como uma resposta à tradicional estrutura estática da internet, começando a seguir uma nova plataforma onde as aplicações são fáceis de usar e permitem que haja muitos emissores, muitos receptores e mais intercâmbios e cooperação. Isso ocorre devido o surgimento da Web 2.0 que possui ferramentas de comunicação interativas com um novo modelo de relação e de construção do conhecimento, sendo assim, uma nova cultura viabilizada pelas Tecnologias da Informação e da Comunicação (TIC).

O grande avanço da internet e da Web 2.0 proporcionou o surgimento das redes sociais virtuais onde as pessoas podem interagir socialmente se conectando através de seus interesses em comum.

É importante lembrar que as Redes Sociais não surgiram com a tecnologia, há muito tempo que nossa sociedade é composta por grupos sociais que reuniam membros específicos com uma ideologia em comum que formaram suas próprias comunidades. Para Franco (2008), as redes sociais não são uma invenção contemporânea:

Não é agora que a sociedade está se constituindo como uma sociedade-rede. Toda vez que socieda- 
des humanas não são invadidas por padrões de organização hierárquicos ou piramidais e por modos de regulação autocráticos, elas se estruturam como redes. O que ocorre na época atual é que a convergência de fatores tecnológicos (como a fibra ótica, o laser, a telefonia digital, a microeletrônica e os satélites de órbita estacionária), políticos, econômicos e sociais, está possibilitando a conexão em tempo real (quer dizer, sem distância) entre o local e o global e, assim, está tornando mais visível a rede social e os fenômenos a ela associados, ao mesmo tempo em que está acelerando e potencializando os seus efeitos, o que não é pouca coisa (FRANCO, 2008, p.43).

Hoje, muito se discute acerca das redes sociais e este referencial é alicerçado por autores contemporâneos que apresentam e analisam a sua configuração, ou seja, a constituição de como as redes sociais se apresentam na sociedade da informação e da comunicação afetando as relações entre as pessoas e a forma como aprendem.

Para Recuero (2009), rede social é gente interagindo socialmente. É um conjunto de pessoas, conectadas a uma estrutura de rede. Cada nó da rede representa um indivíduo e suas conexões, os laços sociais que compõem os grupos. Esses laços são ampliados e alterados a cada novo indivíduo que conhecemos e interagimos.

Já para Castells (1999), rede é composta por um grupo de nós interligados. As redes são estruturas capazes de crescerem de forma ilimitada, incorporando novos nós desde que consigam comunicar-se entre si dentro da rede, ou seja, desde que compartilhem os mesmos valores, ideias e objetivos.

Ainda na perspectiva de Franco (2008), redes são sistemas de nodos e conexões. No caso das redes sociais, tais nodos são pessoas e as conexões são relações entre essas pessoas. As relações em questão são caracterizadas pela possibilidade de uma pessoa emitir ou receber 
mensagens de outra pessoa. Quando isso acontece de fato, dizemos que se estabeleceu uma conexão.

As pessoas usam as redes sociais para manter contato com os amigos, procurar empregos, conhecer pessoas ou como estratégia de marketing das empresas. Segundo pesquisa do instituto de pesquisa Nielsen de abril de 2010 , as redes sociais são acessadas por $66,8 \%$ dos internautas no mundo e o facebook é a rede social mais popular. Os brasileiros são os internautas que mais participam de redes sociais e $86 \%$ dos usuários de internet do país acessam as comunidades virtuais passando cerca de cinco horas por mês nesses sites. Em segundo lugar, estão os italianos com 78\% e em terceiro, os espanhóis com 77\% dos usuários conectados a essas redes. No Brasil, a rede mais popular da Internet é o Orkut e os dados comprovam que as redes sociais estão cada vez mais populares entre os jovens e a participação nelas vem aumentando de forma incrível.

\section{REDES SOCIAIS NO CONTEXTO EDUCACIONAL}

As redes sociais estão cada vez mais presentes no dia a dia das pessoas em todos os segmentos da sociedade e na educação, não poderia ser diferente, porém este assunto ainda gera muita discussão, pois as escolas proíbem o acesso dos estudantes alegando não ter nenhum aproveitamento pedagógico nessas ferramentas, o que é um grande engano. Mas temos que considerar o fato, que todos precisam aprender a utilizar esses recursos de forma adequada, responsável, que não coloque em risco a sua segurança e a escola não deve se furtar dessa tarefa.

As escolas estão evoluindo de forma muito lenta, quando comparadas aos outros setores sociais e não podem, portanto, impedir 
o acesso às redes sociais, temos que educar os alunos a usarem bem essas ferramentas com critérios e responsabilidade. Mesmo que essas redes não tenham sido criadas para fins educacionais, os professores já reconhecem o potencial delas para o ensino.

A internet está cada vez mais presente no sistema educacional e o uso das redes sociais deve ser introduzido no processo pedagógico para romper as paredes da escola, para que aluno e professor possam conhecer o mundo, novas culturas, realidades diferentes, desenvolvendo a aprendizagem através do intercâmbio e aprendizado colaborativo. Para Garcia:

O uso pedagógico das redes oferece a alunos e professores, neste processo, a chance de poder esclarecer suas dúvidas à distância, promovendo, ainda, o estudo em grupo com estudantes separados geograficamente, permitindo-lhes a discussão de temas do mesmo interesse. Mediante esta tecnologia, o aluno sairá de seu isolamento, enriquecendo seu conhecimento de forma individual ou grupal. Poderá fazer perguntas, manifestar idéias e opiniões, fazer uma leitura de mundo mais global, assumir a palavra, confrontar idéias e pensamentos e, definitivamente, na sala de aula não ficará mais confinada a quatro paredes. Isto quer dizer que o uso desta tecnologia poderá criar uma nova dinâmica pedagógica interativa, que se inserida num projeto pedagógico sólido, sem dúvida, contribuirá e muito para a formação moderna dos alunos (GARCIA, 2000, p.5).

Espera-se que as redes sociais não apenas contribuam com a educação, mas estimulem mudanças positivas nos métodos de ensino, aprendizado e estudo, pois com o surgimento da web 2.0 permitindo a interação mútua, essa relação acontece por meio de softwares e sites que conectam os usuários a diversas linguagens e Comunidades Virtuais, onde um grupo de pessoas se comunica e interage de acordo 
com suas afinidades. Para elucidarmos tal afirmação veja o que diz Recuero:

As comunidades virtuais são agregados sociais que surgem da Rede [Internet], quando uma quantidade suficiente de gente leva adiante essas discussões públicas durante um tempo suficiente, com suficientes sentimentos humanos, para formar redes de relações pessoais no espaço cibernético [ciberespaço] (RECUERO, 2005, p.5).

A relação de comunicação e de interatividade entre os usuários se faz através de variadas formas de linguagem, sejam iconográficas, audiovisuais ou textuais. Sendo assim, o leitor não é um simples receptor de informações, mas interfere, manipula, modifica, reinventa. A partir dessas leituras, a sistematização das informações não é considerada estática e isoladamente, e sim como um grande hipertexto, que constantemente é ressignificado e reelaborado. Nessas práticas discursivas, é possível uma interação verbal e visual viva, significativa que desenvolve a argumentação e leva consequentemente a uma maior apropriação dos temas a serem debatidos, organizados, apreendidos.

\section{OS DADOS E SUA ANÁLISE}

A coleta dos dados foi realizada por meio da estatística descritiva utilizando, também, medidas estatísticas como: figuras formato de pizza, que foram criadas com o software Excel. Os dados coletados trazem as vozes dos alunos para compreensão ativa dos adolescentes acerca das redes sociais e o processo de ensino e aprendizagem.

De acordo com Bakhtin (1988), conseguiu-se realizar uma interlocução, uma interação verbal na qual houve um falante e um 
ouvinte que se alternaram e se engajaram em um processo discursivo dialógico.

Os dados obtidos indicaram que $61 \%$ dos alunos da rede pública e 63\% da rede particular acessam internet todos os dias, existe uma pequena disparidade entre as duas escolas no que se refere à quantidade de pessoas que nunca acessam a internet que é de $10 \%$ na escola particular e $0 \%$ na rede pública. Este dado do não acesso da escola particular aponta que o aluno da escola pública não está tão distante dos meios digitais quando se trata de acesso e comunicação.

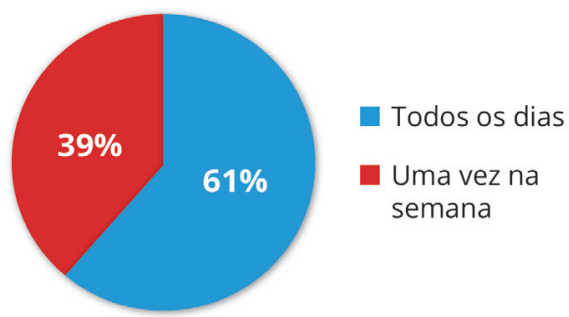

FIGURA 1 - Escola pública - frequência de acesso à Internet FONTE - As autoras

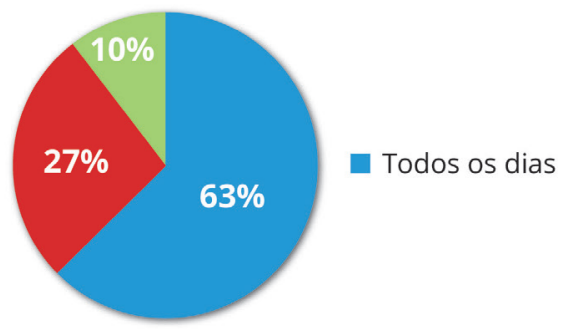

FIGURA 2 - Escola particular - frequência acesso à Internet FONTE - As autoras 
As figuras 3 e 4 indicam que mais de $60 \%$ dos alunos acessam o Orkut em ambas as escolas, o que confirma os dados da pesquisa realizada pelo instituto Nielsen que o Orkut é a rede social mais acessada no Brasil (na época, cito 2010), porém, na escola particular, o $M S N$ é a rede mais acessada pelos jovens. E também se constata que o Twitter tem um número significativo de participantes nas duas escolas, com $16 \%$ na escola pública e $9 \%$ na escola particular confirmando o grande crescimento desta rede social no Brasil nos últimos tempos.

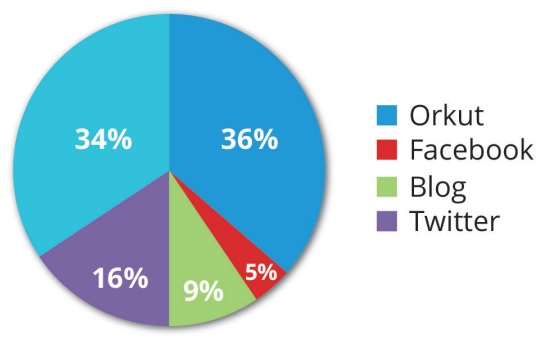

FIGURA 3 - Escola pública - redes sociais que os alunos participam

FONTE - As autoras

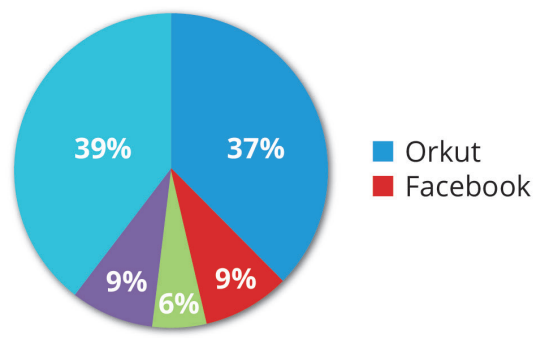

FIGURA 4 - Escola particular - redes sociais que os alunos participam FONTE - As autoras 
As figuras 5 e 6 mostram que $65 \%$ dos jovens da escola pública e $97 \%$ da escola particular utilizam as redes sociais para realizarem pesquisas escolares. Esse resultado demonstra que o uso das redes sociais para fins educativos está se consolidando entre jovens, mesmo quando não são solicitados pelos professores, pois a presença das tecnologias vem provocando mudanças na Educação, criando novas formas de aprendizado, disseminação do conhecimento e, especialmente, novas relações entre professor e aluno.

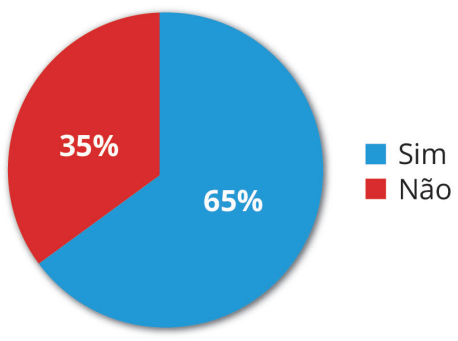

FIGURA 5 - Escola pública - uso das redes sociais para realizar pesquisa FONTE - As autoras

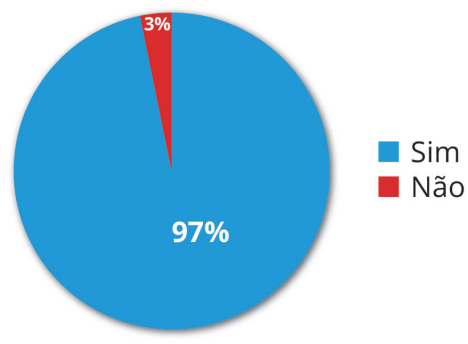

FIGURA 6 - Escola particular - uso das redes sociais para realizar pesquisa FONTE - As autoras 
As disciplinas de Geografia e História são as que os alunos mais encontram material nas redes sociais (figuras 7 e 8), quando eles realizam pesquisas, o resultado oscila entre os $23 \%$ e $30 \%$ nas escolas pública e particular, em segundo lugar, vem Português com $18 \%$ e $14 \%$ e depois Inglês que obteve um número significativo de $18 \%$ na escola pública como se aponta na figura 7. Salienta-se a importância da mediação do professor aos alunos sobre pesquisas na internet já que a rede disponibiliza todo e qualquer tipo de material, mas é preciso que seja um material útil e significativo a construção da aprendizagem do aluno. Sabe-se que a aquisição da informação dependerá cada vez menos do professor. As tecnologias trazem dados, imagens, resumos de forma rápida e atraente e o papel do professor é ajudar o aluno a interpretar esses dados, a relacioná-los, a contextualizá-los.

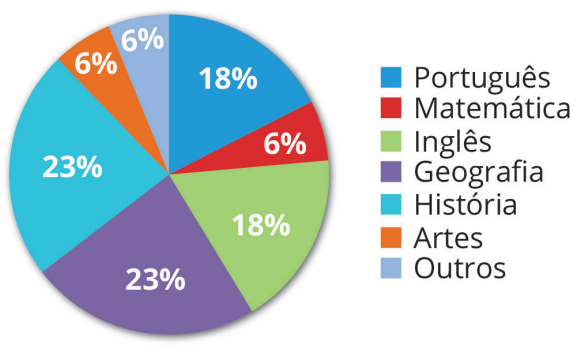

FIGURA 7 - Escola pública - disciplinas que mais encontram material para estudar nas redes sociais

FONTE - As autoras 


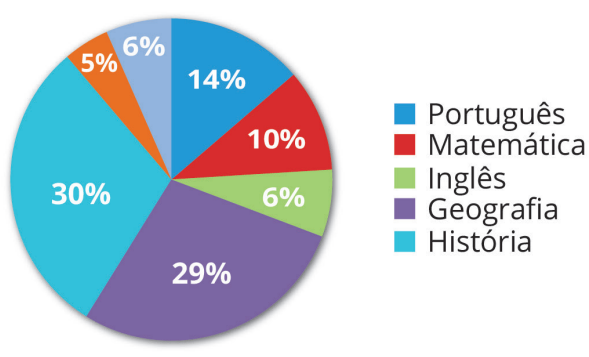

FIGURA 8 - Escola particular - disciplinas que mais encontram material para estudar nas redes sociais

FONTE - As autoras

Nos dados das figuras 9 e 10, verifica-se que o percentual de professores conectado aos alunos através de redes sociais é um pouco maior na escola pública com $50 \%$ e $33 \%$ na escola particular. Este número ainda é considerado pequeno, demonstra que os professores ainda estão se inserindo neste novo contexto tecnológico. Tal dificuldade é enfatizada por Moran:

As mudanças demorarão mais do que alguns pensam, porque nos encontramos em processos desiguais de aprendizagem e evolução pessoal e social. Não temos muitas instituições e pessoas que desenvolvam formas avançadas de compreensão e integração, que possam servir como referência. Predomina a média - a ênfase no intelectual, a separação entre a teoria e a prática (MORAN, 2008, p.16).

A educação precisa acompanhar as mudanças em um ritmo mais acelerado, a sociedade evoluiu e educar tornou-se mais complexo, pois as tecnologias exigem formas dinâmicas de ensinar e aprender, onde o grande desafio dos professores é fazer com que o aprendizado se torne significativo e para que isso aconteça é preciso ousar, criar e refletir sobre sua prática de ensino diante das tecnologias. $\mathrm{Na}$ 
visão de Lévy (1999), a função do professor não deve estar focada na mera transmissão dos conhecimentos, o aprendizado precisa ser construído através de incentivo, o professor precisa ser um incentivador da construção do conhecimento de seus alunos.

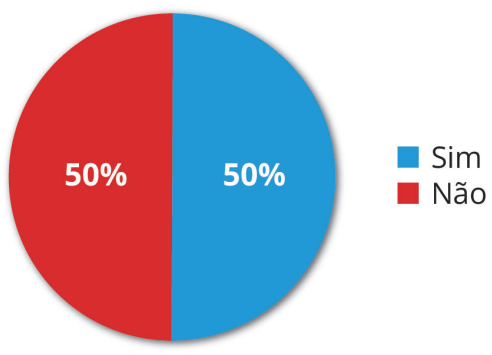

FIGURA 9 - Escola pública - professores conectados aos alunos através das redes sociais

FONTE - As autoras

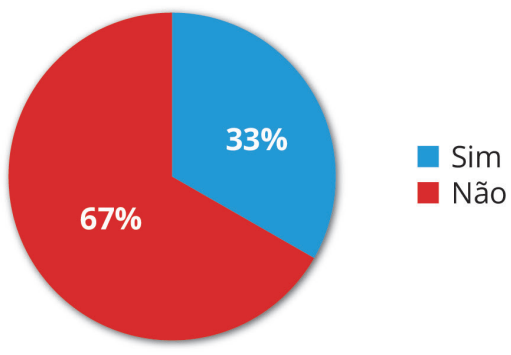

FIGURA 10 - Escola particular - professores conectados aos alunos através das redes sociais.

FONTE - As autoras 
$\mathrm{Na}$ época da pesquisa, as figuras 11 e 12, apontam que o Orkut e o MSN em ambas as escolas eram as redes sociais que os professores mais utilizavam para se conectar com os alunos. Na escola pública, o percentual é de 30\% Orkut, 50\% MSN, 14\% Twitter, 3\% Blog e 3\% Facebook, já na escola particular surgem apenas duas redes sociais: o Orkut e MSN com 47\% e 53\% . Percebe-se que os professores da escola pública trabalham com várias redes mesmo que ainda com um número reduzido.

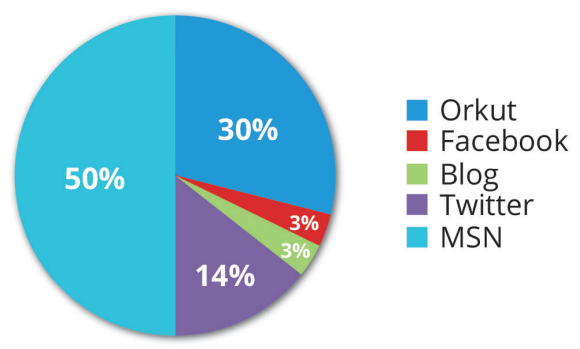

FIGURA 11 - Escola pública - redes sociais que os alunos estão conectados aos professores

FONTE - As autoras

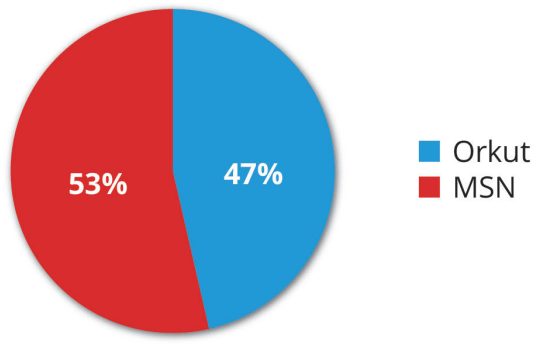

FIGURA 12 - Escola particular - redes sociais que os alunos estão conectados aos professores

FONTE - As autoras 
Segundo Masetto (2000), a mediação pedagógica significa a atitude, o comportamento do professor que se coloca como um facilitador, incentivador e motivador da aprendizagem, ou seja, uma ponte móvel entre o aprendiz e sua aprendizagem que ativamente contribui para que o aprendiz chegue aos seus objetivos.

As figuras 13 e 14 apontam que os alunos se preocupam com o que escrevem nas redes sociais quando são solicitados pelos professores. O percentual de 39\% da escola pública respondeu que se preocupa com o que as pessoas vão pensar em relação ao que escreveu, por isso tem mais atenção na hora de elaborar seu texto e 39\% responderam que o fato de serem solicitados pelos professores, eles são forçados a estudar mais. Já na escola particular, apenas 10\% revelam que têm essa preocupação ao escrever e $64 \%$ dizem ser forçados a estudar mais para elaborar a escrita. Os resultados apontam que, quando os professores trabalham com as redes sociais para realizar atividades junto aos seus alunos, eles provocam ações colaborativas instrumentalizadas pelas tecnologias, assim enfatiza Almeida:

O uso das TICs na escola, principalmente com o acesso à internet, contribui para expandir o acesso à informação atualizada, permite estabelecer novas relações com o saber que ultrapassam os limites dos materiais instrucionais tradicionais, favorece a criação de comunidades colaborativas que privilegiam a comunicação e permite eliminar os muros que separam a instituição da sociedade (ALMEIDA, 2003, p.114).

Dessa forma, o educador deixa de ser dono do conhecimento e transforma-se no incentivador e facilitador do ensino-aprendizagem, tanto na sala de aula, como fora dela. 


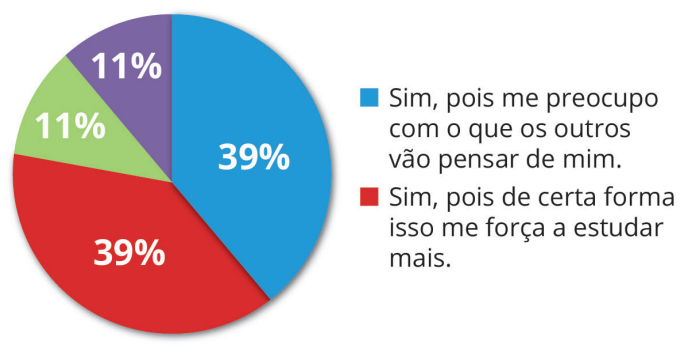

FIGURA 13 - Escola pública - a dedicação na elaboração do texto quando são solicitados pelo professor

FONTE - As autoras

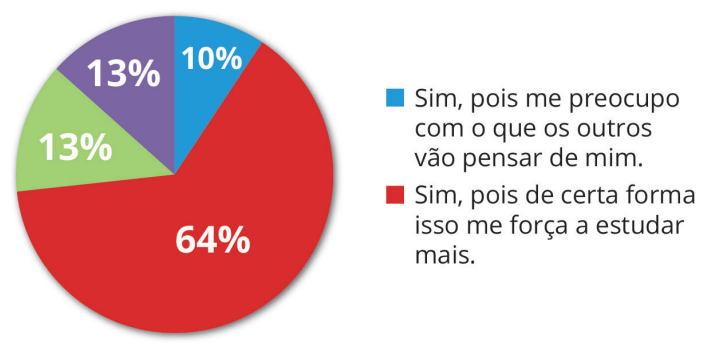

FIGURA 14 - Escola particular - a dedicação na elaboração do texto quando são solicitados pelo professor

FONTE- As autoras

Nas falas dos adolescentes, entende-se que o fato de participarem de uma rede social por intermédio do professor desperta no aluno uma maior responsabilidade na hora de se expressar e escrever sua opinião. A pesquisa revelou, por unanimidade, que os alunos destacam a facilidade no processo de aprendizagem e também o fortalecer da relação com o professor. Isto fica evidente nas vozes dos alunos da rede pública e particular quando perguntados sobre como se sentem em saber que podem manter contato com seus professores através das redes sociais. 
"Sim, pois você sente que aumenta mais a comunicação fora da sala, é muito bom poder manter contato com o professor dessa forma você se torna mais amiga dele"(Aluno A- Escola Pública, informação verbal).

‘É bom, pois estamos mantendo contato mesmo sem está na escola” (Aluno B- Escola Pública, informação verbal).

'Sim, pois você sente que aumenta mais a comunicação fora da sala, é muito bom poder manter contato com o professor dessa forma você se torna mais amigo dele"(Aluno A- Escola Particular, informação verbal).

‘É bom, pois estamos mantendo contato mesmo sem está na escola” (Aluno B- Escola Particular, informação verbal).

Através dessas falas, fica claro que se não der voz ao aluno, impede-se seu processo de compreensão ativa. Para Bakhtin (1988), uma situação compartilhada favorece a aprendizagem.

A proximidade entre professores e estudantes nas redes sociais fortalece a relação no ensino presencial permitindo, assim, uma maior proximidade entre eles, por estes e outros motivos, as redes sociais educacionais evidentemente contribuem para o aprendizado quando utilizadas com responsabilidade e sabedoria pelos difusores da informação.

Quando perguntados se os professores, que procuram utilizar sites de relacionamento, enriquecem a disciplina que lecionam e 
mantêm aquecida a relação professor aluno, os alunos foram unânimes em responder de forma afirmativa:

'Sinto-me bem, pois isso me passa confiança e pode até melhorar o convívio com o professor em sala de aula" (Aluno C- Escola Pública, informação verbal).

'Desperta um certo conforto, pois em sala de aula temos o professor como uma autoridade e numa rede social o espírito autoritário se converte numa companhia interativa" (Aluno D- Escola Pública, informação verbal).

'Sim porque hoje em dia existem vários meios para enriquecer a disciplina e nos colocar por dentro do assunto" (Aluno C- Escola Particular, informação verbal).

'Sim porque o aprendizado fica mais dinâmico"(Aluno DEscola Particular, informação verbal).

Para Moran (2000), bons educadores seduzem os alunos não apenas com ideias, mas também pelo contato pessoal, seja na sala de aula ou fora dela sempre surpreende com algo, na forma de se relacionar, olhar, comunicar e agir. São poços abundantes de descobertas.

As mudanças na educação não dependem apenas dos professores, mas também de termos governantes, diretores e coordenadores mais abertos, que compreendam todas as dimensões que abrangem o processo pedagógico, que apoiem os professores contribuindo para que haja um ambiente de maior inovação, intercâmbio e comunicação. 
Nesta análise, acredita-se no fato de que a construção do conhecimento é adquirida através de novos processos metodológicos de aprendizagem, pois estes permitem às instituições escolares um novo diálogo com os indivíduos e com o mundo, pois é inegável que a presença de tecnologias digitais da informação e da comunicação propiciam aos professores e alunos uma reformulação de suas relações de aprendizagem.

\section{CONSIDERAÇÕES FINAIS}

A tecnologia sem dúvida tem conquistado espaço na sociedade, dia após dia, somos surpreendidos com novas invenções que superam inclusive as nossas expectativas. Na esfera da educação, muito ainda precisa ser feito, pois a tecnologia requer um olhar mais abrangente, envolvendo novas formas de ensinar e de aprender, condizentes com o modelo da sociedade do conhecimento, o qual se caracteriza pelos princípios da diversidade, da integração e da complexidade.

A escola vista como espaço de construção do conhecimento e de inclusão deve abrir as portas para a nova Era da Informação e da Comunicação, incentivar e motivar os professores a abandonar metodologias tradicionalistas e usar novas metodologias que incorporem as TDIC, tais como as redes sociais.

É importante destacar que o uso das redes sociais tem contribuído para uma melhor relação entre professores e alunos facilitando assim o processo de ensino e aprendizagem.

É possível elucidar alguns achados do estudo que merecem atenção como: A maioria dos jovens acessa Internet todos os dias, esta informação demonstra que eles já incorporaram rapidamente 
as tecnologias. Um percentual de $10 \%$ de alunos da rede particular nunca acessa a Internet, isto comprova que os alunos da escola pública em termos de inclusão digital não estão em desvantagem em relação à escola particular. Todos os alunos entrevistados fazem parte de alguma rede social, ficando evidente que não se podem ignorar estes importantes meios de comunicação e interação tão presentes nas vidas dos adolescentes. Mais de 65\% acessam as redes para realizarem pesquisas escolares e este dado comprova que os alunos têm utilizado as redes para fins educativos, mesmo quando não são solicitados pelos professores. O número de professores conectados aos alunos através de redes sociais ainda é pequeno se comparado ao avanço da tecnologia. Os alunos têm mais cuidado com o que escrevem nas redes sociais quando sabem que os professores têm acesso ao seu texto Os adolescentes por unanimidade relatam que o contato com os professores, através das redes sociais, contribui consideravelmente para uma boa relação entre eles.

Diante de tais colocações, fica evidente a necessidade dos professores acompanharem com mais entusiasmo o avanço tecnológico, pois numa sociedade em que tudo se transforma com muita rapidez, é preciso que estejam atentos à sua própria formação para trabalhar efetivamente com as tecnologias, filtrar as ferramentas que não trazem mudanças positivas nas práticas educativas e se apropriar daquelas que podem construir uma nova escola, apropriada à Era da Informação e do Conhecimento.

Neste contexto, é importante lembrar que o uso das redes sociais pode contribuir significativamente com o processo de ensino e aprendizagem, bem como expandir o que é aprendido em sala de aula desde que sejam trabalhadas de forma criativa, pois um dos pontos 
positivos das redes é a participação ativa dos alunos na construção de sua própria aprendizagem.

\section{REFERÊNCIAS}

ALARCÃO, I. Professores reflexivos em uma escola reflexiva. São Paulo: Cortez, 2003, p.31.

ALMEIDA, M. E. B.; VIEIRA, A. T. ALONSO, M. (Orgs). Gestão educacional e tecnologia. São Paulo: Avercamp, 2003, p.14.

BAKHTIN, M. M. (Voloshinov, V.) Marxismo e filosofia da linguagem. São Paulo: Hucitec, 1988.

BENCINI. R.. Da informação ao conhecimento. Revista Nova Escola, jun/jul, 2002.

CASTELLS, M. A sociedade em rede. A era da informática: Economia, Sociedade e Cultura, v.1. São Paulo: Paz e terra, 1999.

DEMO, P. Educação hoje: "novas"tecnologias, pressões e oportunidades. São Paulo: Atlas, 2009.

GUIMARÃES, Â. M; DIAS, R. Ambientes de aprendizagem: reengenharia da sala de aula. In: Novas tecnologias, novos textos, novas formas de pensar. 3. ed. Belo Horizonte: Autêntica, 2006. FRANCO, A. Escola de redes: novas visões sobre a sociedade, o desenvolvimento, a internet, a política e o mundo globalizado. Curitiba: Saturnos Assessoria em Comunicação Social S/C Ltda, 2008, p.43. 
GARCIA, P. S. Qualidade e informática: a escola pública do ano 2000. Artigo apresentado e publicado no Congresso Nacional de Informática Pública (CONIP) 1995, p.5.

LÉVY, P. Cibercultura. São Paulo: Ed. 34, 1999, p.99.

LÜDKE, M; MOREIRA. A.F. B; CUNHA. M.I. Internacionais sobre a formação de nossos professores. Repercussões de tendências. In: Revista Educação \& Sociedade. (Cedes), n. 68. Campinas/SP, 1999.

MASSETO, M. T. Mediação pedagógica e o uso da tecnologia. In Novas tecnologias e mediação pedagógica. 16. ed. Campinas, SP: Papirus, 2000.

MORAN, J. M. Novos caminhos do ensino à distância. Informe CEAD - Centro de Educação à Distância, Ano 1, n. 5, out/nov/dez. Rio de Janeiro: SENAI, 1994.

MORAN, J. M. Mudanças na comunicação pessoal: gerenciamento integrado da comunicação pessoal, social e tecnológica. São Paulo: Paulinas, 1998, p.16. . Ensino e aprendizagem inovadores com tecnologias audiovisuais e telemáticas. In. Novas tecnologias e mediação pedagógica. 16. ed. Campinas, SP: Papirus, 2000.

PORTO, M. E. As tecnologias de comunicação e informação na escola: relações possíveis... relações construídas. Revista Brasileira de Educação. v.11, n.31, jan/abr. 2006, p.43-57. 
RECUERO, R. Redes sociais da internet. Porto Alegre: Sulina, 2009. Comunidades virtuais em redes sociais na internet: uma proposta de estudo. E-Compós, v.4. Brasília, 2005.

SILVA, M. Sala de aula interativa. Rio de Janeiro: Quartet, 2000, p.15.

VALENTE, J. A. Informática na educação: a prática e a formação do professor. In: Anais do IX ENDIPE (Encontro Nacional de Didática e Prática de Ensino). Águas de Lindóia, 1998, p.17. 


\section{AS GERAÇÕES DE INFOGRÁFICOS}

\section{COMUNICATIVOS: PROPOSTAS E}

POSSIBILIDADES PARA A EDUCAÇÃO A DISTÂNCIA

\section{Carolina Cavalcanti Bezerra Maria Lúcia Serafim}

\section{INTRODUÇÃO}

O presente artigo que é resultado das práticas cursadas durante a especialização em Novas Tecnologias na Educação é fruto de produção monográfica de conclusão de curso introduz os preceitos, fundamentos e características da infografia como prática comunicacional a partir de pesquisa bibliográfica que buscou, por referenciais sobre infografia, Educação a Distância $(\mathrm{EaD})$ e infografia no ensino a distância. Como metodologia para elaboração do estudo, optamos pelo denominado como "estado da arte", ou seja, algo que investiga os referenciais bibliográficos disponíveis apontando, comparando e dialogando com a produção científica referente à temática pesquisada (ANGELUCCI et al., 2004; MESSINA, 1999).

1 Da segunda turma encerrada em 2010. A especialização é oferecida pela UEPB e está em sua terceira turma (2011) composta basicamente de docentes do ensino Estadual da Paraíba. 
Objetivamos, inicialmente, a introdução teórica às características infográficas respaldadas por autores nacionais e internacionais que tratam de questões como interatividade e mediação. Em um segundo momento, apresentamos a evolução da infografia no que diz respeito a sua construção ao longo das décadas conjuntamente com a evolução da internet e sua identificação com a modalidade de ensino a distância como ferramenta prática para o desenvolvimento de atividades não presenciais. Dessa forma, a utilização da infografia na educação a distância tanto como ferramenta informativa e comunicativa e também como resultado de um processo de ensino e aprendizagem se revelam como prática a ser socializada e explorada pela modalidade.

Para o desenvolvimento deste artigo apresentamos autores que constroem a temática sobre a modalidade a distância, a comunicação e a interatividade, sendo importantes na pesquisa em pauta apresentada; dentre eles: Belloni (2006); Feuerstein (apud SOUZA; DESPRESBITERIS, 2004); Morin (2001); Moran (2000) e Lévy (1993). Em relação às conceituações sobre infografia destacamos Amaral (2009); Leturia (2008); Sanches (2001); Borras; Caritá (2000); Marcondes Filho (2000) e Alonso (1998).

A Educação a Distância é um modelo de comunicação que incorpora em seu todo distintas formas (fala, escrita, visão, uso de cores, audição, entre outras) e ferramentas comunicacionais convergentes que geram conhecimento através de práticas conectadas com a realidade do século XXI. Dessa forma, ressaltamos a EaD como uma:

(...) forma de ensino que possibilita a auto-aprendizagem, com a mediação de recursos didáticos sistematicamente organizados, apresentados em diferentes suportes de informação, utilizados isoladamente ou combinados, e veiculados pelos diferentes meios de comunicação (CEARÁ, 2000). 
Ou ainda uma

Modalidade educacional na qual a mediação didático-pedagógica nos processos de ensino e aprendizagem ocorre com a utilização de meios e tecnologias de informação e comunicação, com estudantes e professores desenvolvendo atividades educativas em lugares ou tempos diversos (BRASIL, 2005).

Sendo assim, pretendemos neste artigo voltar os olhares para a importância das constantes inovações no processo comunicativo e suas potencialidades que se apresentam por meio das Tecnologias da Informação e Comunicação (TIC), como a infografia, que se apresentam como possibilidades para o processo educativo.

Para tanto, alguns autores servem como referência para a escrita sobre educação a distância e devem ser lembrados neste princípio de construção do conhecimento. Belloni (2006), por exemplo, perpassa por vários vieses possíveis ao analisar a $\mathrm{EaD}$, mas se detém com extrema clareza sobre os desafios das Tecnologias da Informação e Comunicação (TIC) no que diz respeito à mediatização e o uso da tecnologia na educação. Seria a metodologia da EaD suficientemente capaz de ensinar e educar com tantas possibilidades tecnológicas?

Morin (2001) e Lévy (1993) dentro da mesma contextualização sobre a importância das tecnologias e da internet apontam para a importância da construção de saberes de forma coletiva e, para tal, apontam que não basta ter todas as ferramentas disponíveis 'há a necessidade de apre(e)nder o correto uso das mesmas, para que as informações acessadas de forma não-linear pelos usuários se transformem em conhecimento"(BEZERRA, 2010, p.11).

Um pouco mais distante dessa unidade tecnológica utilizada, nos dias atuais, e na EaD, apresentam-se as bases teóricas sobre 
a mediação como princípio educacional de Feuerstein $(2004)^{2}$ que propiciam a análise pelo viés da cognição onde a interação e conceituações próximas ao interacionismo trazem uma nova leitura para o processo de ensino e aprendizagem.

Sendo assim, detalhamos a seguir a infografia como processo, meio e ferramenta de comunicação, interligando-a ao ensino a distância como possibilidade real de maior interatividade entre todas as partes do processo de aprendizagem mediado em ambientes virtuais de aprendizagem.

\section{PROCESSO DE COMUNICAÇÃO AO LONGO DA HISTÓRIA: A GERAÇÃO INFOGRÁFICA}

Como é de conhecimento, o grande marco histórico da evolução da comunicação se deu com a invenção da prensa por Gutenberg no século XV e consequentemente da possibilidade de reprodução em maior escala de escritos como livros e jornais, fazendo com que a informação se tornasse mais acessível. No final do século XX, com o que se convencionou chamar de "Gornalismo da era tecnológica"é que a linguagem jornalística alcançou patamares de alta qualidade técnica das imagens. Essa qualidade ‘...] impõe-se como modelo estético, inicialmente na televisão, mas também nos painéis publicitários e em todas as mensagens visuais [...]”, e consequentemente a '[...] aparência e a dinamicidade da página é que se tornam agora decisivos"(MARCONDES FILHO, 2000, p.31, grifo nosso).

2 Os autores reforçam nesta leitura as similaridades dos estudos de Feuerstein com os de Piaget, Vygostsky e até Paulo Freire. No caso dos dois primeiros é evidenciada a influência de ambos na construção de suas teorias, tais como a Experiência de Aprendizagem Mediada (EAM). 
Entendamos, então, o que vem a ser infografia ou infográfico(s). Os infográficos são uma criação do jornalismo, mas do jornalismo contemporâneo. Evidenciaram-se a partir da metade do século XIX com a informação gráfica estabelecendo seu local de atuação. Sua expressão em códigos verbais e visuais data da história do surgimento do jornal impresso quando os textos eram misturados às técnicas de xilografia e litografia ${ }^{3}$. São duas suas principais características: a aparência/corpo (construção a partir de textos e imagens) e a dinamicidade (ou velocidade da informação).

Os infográficos se constituem destes elementos e podem assim perfazer sua importância por serem "uma peça informativa, realizada com elementos icônicos e tipográficos, que permite ou facilita a compreensão dos acontecimentos, ações ou coisas [...] e acompanha ou substitui o texto informativo"(SANCHES, 2001, p.21-26).

Ou seja,

En un infográfico el texto es un elemento complementario, pues sirve para situar y explicar el contenido del dibujo. Ahora bien, así como el dibujo no puede reducirse a mera ilustración, ya que lo informativo ha de primar siempre sobre lo estético, pensamos que tampoco el texto puede ser tratado como un simple recurso decorativo, de relleno o adorno. Que sea complementario no implica que sea accesorio (ALONSO, 1998).

3 A litografia elemento importante na construção dos infográficos, só em 1885 é utilizada pela primeira vez em jornais. No século XX, anos 70, as impressões já podiam ser feitas em cores e a consolidação dos computadores nas redações dos jornais só aconteceu nos anos 80 também com a apresentação de programas de computação gráfica (VELHO, 2008). 


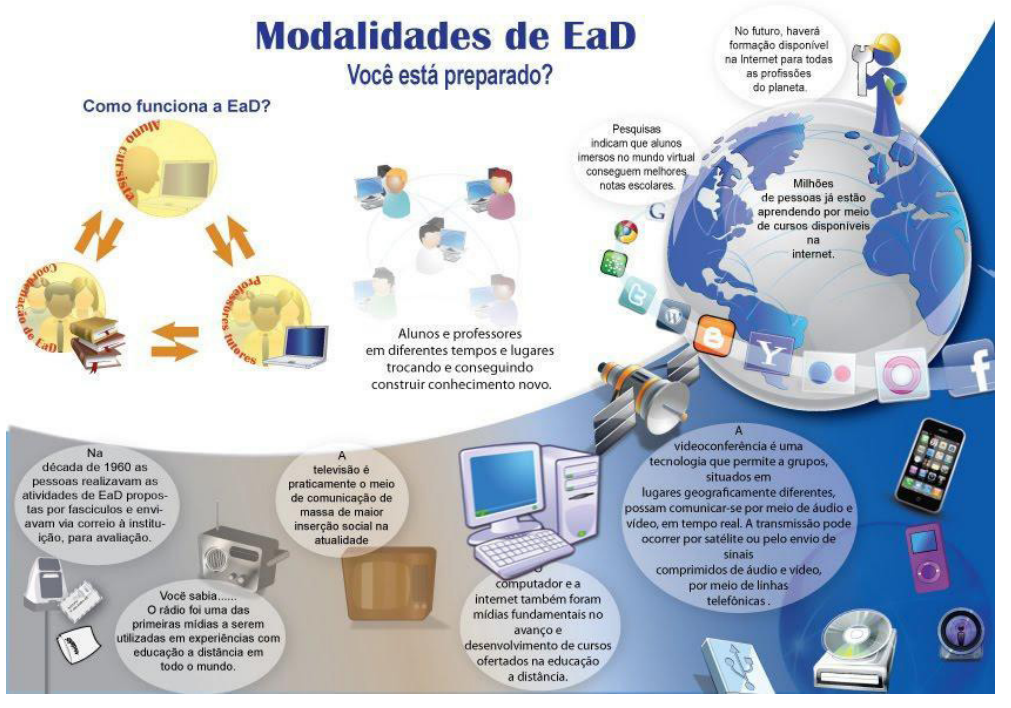

FIGURA 1 - Infográfico sobre educação a distância.

FONTE - Disponível em http.//andreacastagini.blogspot.com.br/2010/10/mais- infograficos.html Acesso em 22 nov. 2012

Um infográfico apresenta algumas características básicas: um Título, um Texto, Corpo e Fonte atentando para a construção de uma informação através de uma narrativa linear (BORÁS; CARITÁ, 2000; LETURIA, 1998). Além de ser uma ferramenta jornalística que expressa o conteúdo de uma matéria, de uma informação. Élargamente utilizado e produzido também por alunos de Comunicação Social e por blogueiros que enriquecem seus diários on-line com infográficos de todos os tipos.

Porém, como proposta do estudo realizado e resultado do Curso de Especialização, propõem-se como ferramenta no processo de aprendizado dentro dos Ambientes Virtuais de Aprendizagem 
$(\mathrm{AVA})^{4}$ no ensino a distância. Sendo assim, a infografia não é apenas uma forma de comunicação, mas uma metodologia que se utiliza de ferramentas específicas que evoluem com a velocidade da tecnologia das redes comunicativas.

Expomos abaixo um Sistema Arbóreo de Evolução dos Infográficos que, segundo Amaral (2009), apresenta a evolução das características e técnicas infográficas correlacionando-as com ferramentas disponíveis de comunicação:

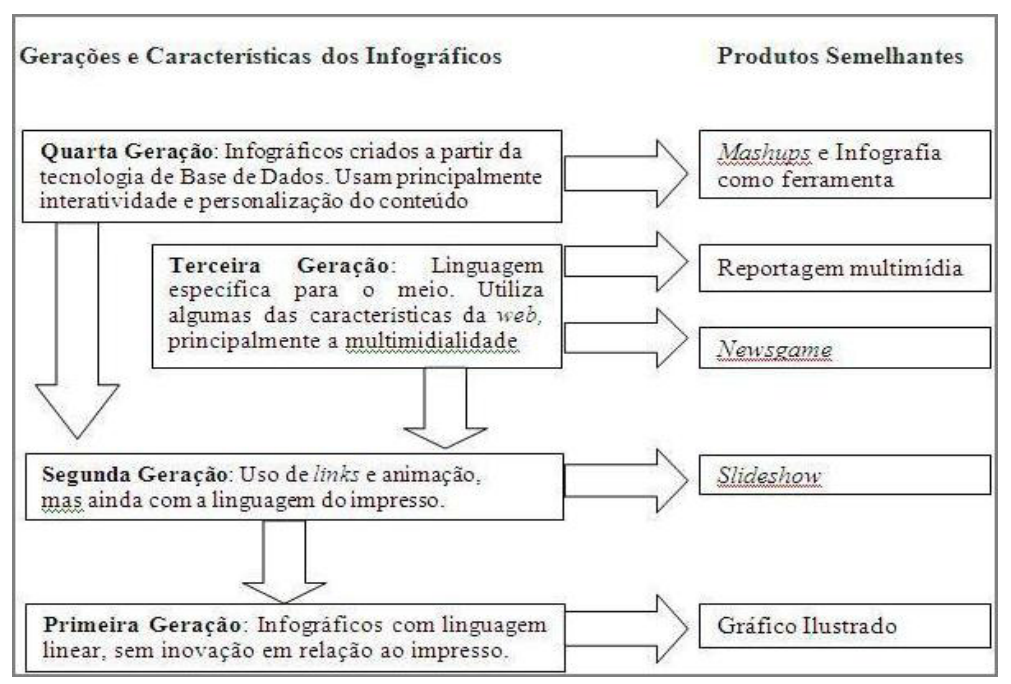

FIGURA 2 - Gerações de infográficos na Comunicação FONTE - AMARAL, 2009

4 Virtual Learninh Environment são softwares utilizados para construção de cursos nas mais diversas instâncias de ensino tendo a internet como veículo. Utilizados na Educação a Distância servem para acompanhar os alunos em cursos de graduação e pós-graduação. Alguns cursos presenciais também utilizam plataformas de ensino como o Moodle (de livre acesso) ou o Teleduc (desenvolvido pela Universidade Estadual de Campinas) para acompanhar atividades extrapresenciais de seus alunos. 
Detalhadamente, expomos as quatro gerações disponíveis de infográficos - já que uma não anula a outra, pelo contrário, são complementares - presentes com mais força no jornalismo eletrônico. O que distinguirá umas das outras serão: 1) a apresentação e 2) a forma de linguagem expressa. Vale também ressaltar a correlação entre o nível de complexidade e de aprendizado: quanto mais complexo mais se exigirá no processo de aprendizagem.

O primeiro nível, que tem como produto final relacionado um gráfico, apresenta linguagem de simples assimilação, bem como, recursos também simplificados. São conhecidos como infográficos

\section{diagramas.}

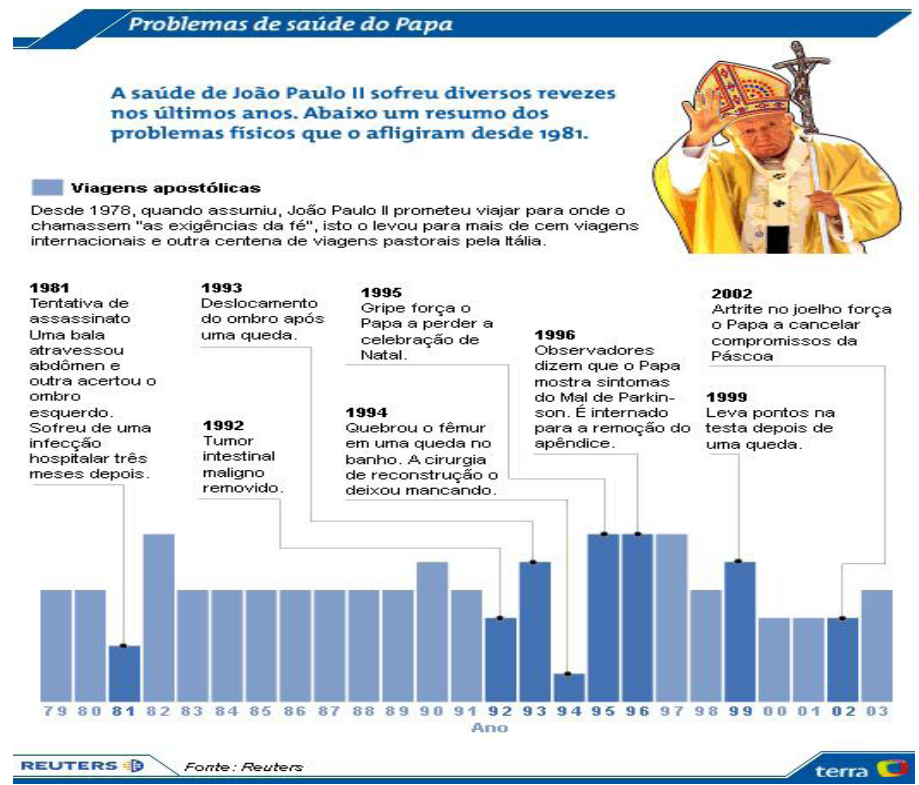

FIGURA 3 - Contextualização da saúde do Papa, de forma cronológica e facilmente compreensível

FONTE- Disponível em http://img.terra.com.br/i/2003/10/07/79504_in.gif Acesso em 08 set. 2010 
Como parte dessa primeira geração, encontramos os infográficos denominados de iluministas, que se caracterizam pela utilização de textos e ícones lembrando muito no produto final com manuscritos da Idade Média; os carto-infográficos, que se utilizam de mapas e informações textuais, sendo muito utilizados na área de Turismo; e por fim, os quadros de resumos, que são carregados de informações e resumem ao máximo as informações transmitidas (BEZERRA, 2010).

A característica principal dessa primeira geração está na apresentação/transmissão da informação de forma estática, simples e com uso apenas dos recursos visuais de texto e cores. Não há interatividade com o leitor. A mensagem apenas é repassada.

A partir da segunda geração infográfica várias ferramentas que tornam o trabalho mais elaborado, como o equilíbrio entre imagens e texto serão exploradas, tais como os recursos multimídia, por exemplo, trazendo a interatividade para o processo comunicativo. $\mathrm{O}$ produto final desta geração é o slideshow ${ }^{5}$ que incorpora a si a apresentação em movimento com cores e sons.

Neste momento, a evolução dos infográficos se deu a partir do próprio desenvolvimento das ferramentas computacionais que permitiram a evolução da forma como a comunicação se dava. Através de ferramenta de construção contínua de informações, passando de tela a tela, podendo ser inseridos áudio e imagem, a apresentação de dados começa a proporcionar uma leitura mais dinâmica e visualmente atrativa. Neste momento, a interatividade visual, proporcionada pela ferramenta, atrai o interesse do público que busca captar mais dinamicamente os dados.

5 Desenvolvido a partir de softwares como o PowerPoint do pacote Office e seus similares. 


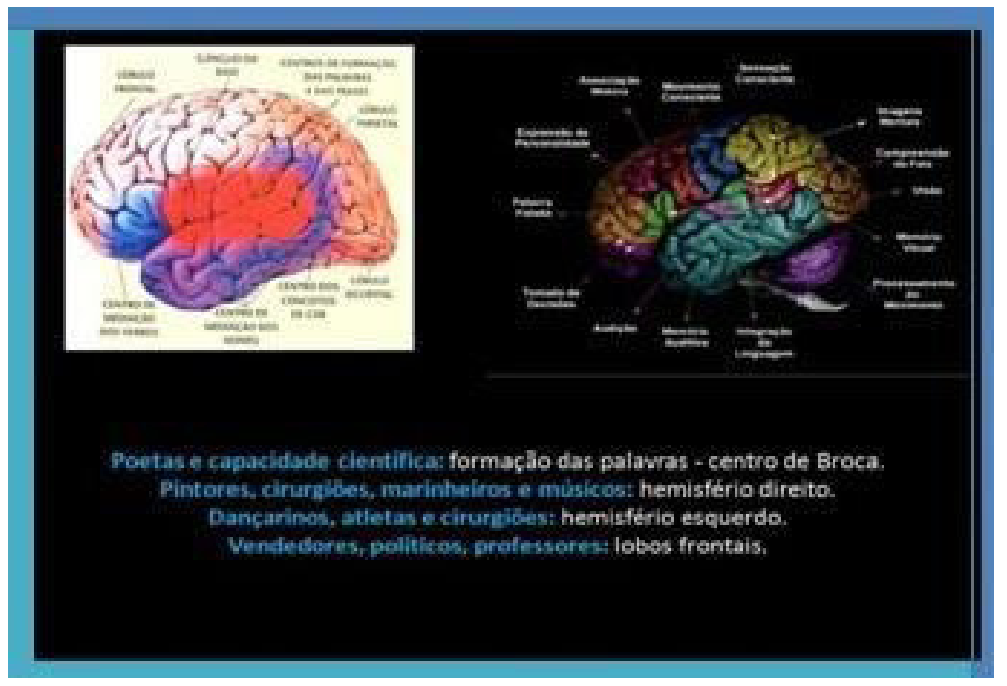

FIGURA 4 - Exemplo de apresentação em slideshow FONTE - BEZERRA, 2010.

Apesar da possibilidade de utilização de vídeos e áudio, por exemplo, a visualização ainda está mais próxima da mídia impressa, tal como jornais e revistas lembrando muito a metodologia investigativa das Webquests ${ }^{6}$.

A terceira geração caracteriza-se por uma linguagem específica para o meio digital on-line e utiliza algumas das características da web, principalmente a multimidialidade. Tem como produtos e linguagens finais a reportagem multimídia e o newsgame.

A aprendizagem multimídia acontece a partir do momento em que a construção do conhecimento é feita através da representação mental de palavras e imagens, tendo em vista que o aprendizado se dá melhor desta forma do que somente com palavras. Para que o

6 Conceito criado em 1995 por Bernie Dodge, professor californiano, define uma metodologia de uso da internet como recurso de pesquisa, criativa e investigativa, sendo considerada em seus aspectos pedagógicos, muito dinâmica e informativa. 
processo de aprendizagem ocorra, o importante é utilizar a tecnologia multimídia para a ampliação da cognição humana. Para tanto, alguns princípios podem ser apontados na aprendizagem: 1) aprende-se melhor com a combinação de imagens e sons (princípio multimídia); 2) proximidade entre palavras e imagens (proximidade espacial); 3) apresentação simultânea de palavras e imagens (proximidade temporal); 4) coerência na utilização das palavras e dos símbolos (caso não haja necessidade devem ser excluídas); 5) uso de animação e narração (modalidade) e 6) superioridade da utilização de narração e animação (redundância) (MAYER, 2005).

Destacamos como relevantes aos nossos objetivos os newsgames, processo comunicativo que, com acesso a banda larga, possibilita ao leitor acompanhar notícias específicas e divertir-se ao mesmo tempo. Porém, vale ressaltar que esse tipo de infografia funciona melhor no tratamento de assuntos que têm longa duração com um histórico informacional. ${ }^{7}$

7 [...] adotando a definição de informação como “transmissão de conhecimentos”, nesse caso, a informação das narrativas dos games pode nem sempre aparecer de forma explícita, clara, como numa exposição de aula tradicional, ou numa manchete de jornal, de forma descritiva, mas de forma sedutora, pois "Quanto mais estivermos pessoalmente envolvidos com uma informação, mais fácil será lembrá-la”[...]. Disponível em: < http://webmultimidia.blogspot.com/2009/06/conceitos_19.html>. Acesso em: 06 out. 2010. 


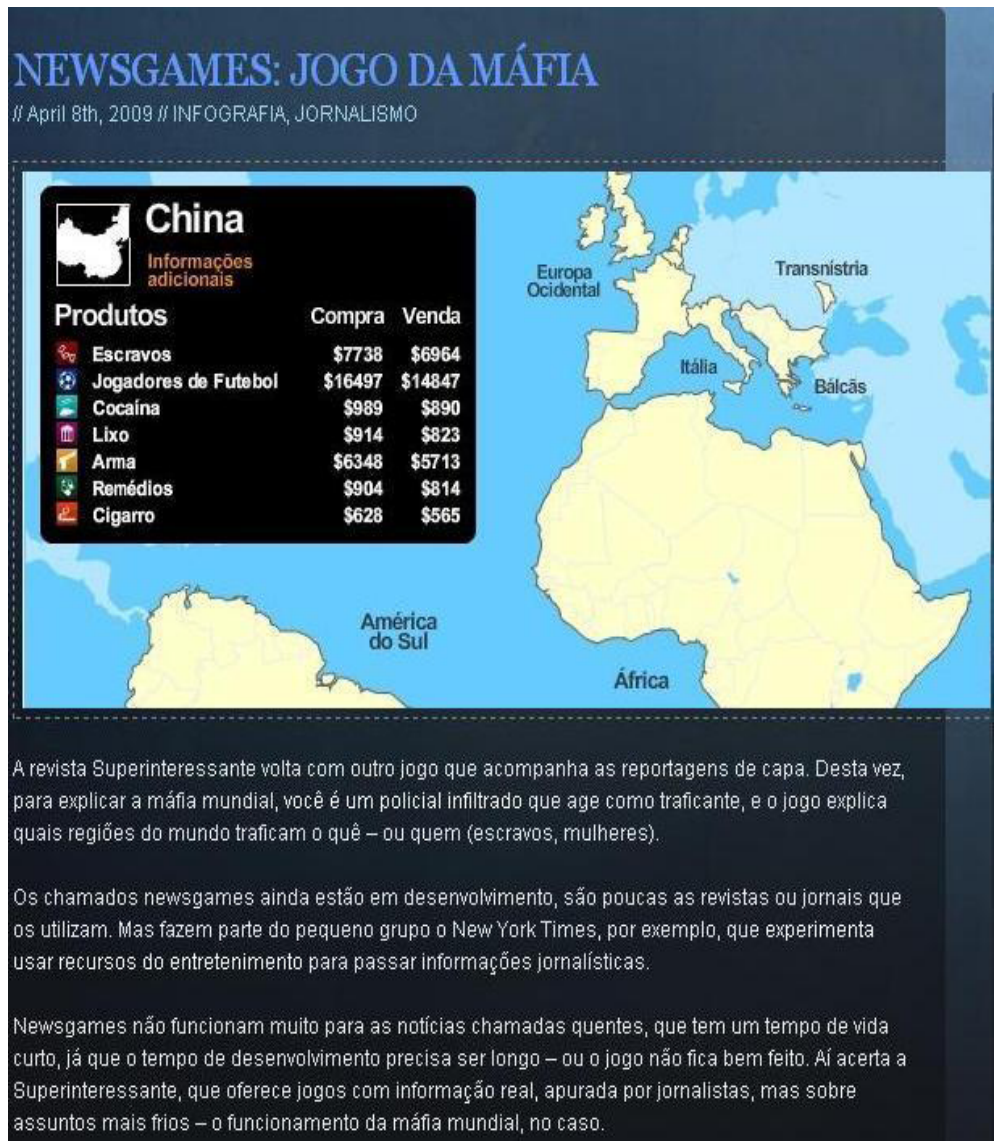

FIGURA 5 - Newsgame: um histórico informacional

FONTE: http://www.andredeak.com.br/2009/04/08/newsgames-jogo-da-mafia/ Acesso em 08 set. 2010

Como modelo informacional, funcionaria muito bem dentro da modalidade não presencial. Um conteúdo que abordado por mais de um semestre, por exemplo, poderia muito bem contar com o newsgame para tornar o aprendizado mais dinâmico e intera- 
tivo ${ }^{8}$. Para o jornalismo, essa "Brincadeira de informar", além de ser atrativa, faz com que o leitor busque a informação diariamente. Essa característica para a $\mathrm{EaD}$ não somente facilitaria muito o interesse pelo aprendizado, mas o acesso mais constante ao ambiente virtual de aprendizagem.

E, por fim, a quarta geração de infográficos, criados a partir de tecnologia de base de dados, usa principalmente interatividade e a personalização do conteúdo, tendo como produtos e linguagem final os mashups e a infografia como ferramenta.

Os infográficos da quarta geração, ou infográficos animados, permitem não só o acesso à informação, mas também a interação do leitor com a transmissão da comunicação infográfica.

Os mashups são websites ou uma aplicação da web, que combinam a funcionalidade ou conteúdo de fontes existentes tais como Web Services (através do uso de API's), Web Feeds (RSS, Atom), ou mesmo outros sites (por captura de tela). Para ambientes virtuais de aprendizagem cuja característica primeira é o acesso gratuito ao software, incorporar novas aplicações, também gratuitas, traz um enriquecimento ao ensino a distância. Principalmente aquele oferecido por universidades públicas onde o custo com a operacionalização é alto.

A combinação de dados capturados da internet para a EaD, além de ser uma maneira criativa de construção do conhecimento, traz à educação a distância algo fundamental, a interatividade, haja

8 No ensino de História, o descobrimento do Brasil poderia ser contato com o uso de ilustrações de caravelas, tendo como personagens portugueses e índios. E como referências de aprendizado o extrativismo do pau-brasil, a tentativa de escravização dos indígenas, a troca de utensílios entre eles etc. Tudo isso de forma contínua, onde um aprendizado inicial servirá para a construção de um novo conhecimento mais adiante. 
vista que, buscar informações, construir conhecimento e disseminar o aprendizado, passa pela questão da troca de comunicação dentro da modalidade.

Abaixo um mashup onde usuários de várias localidades do mundo discutem de maneira ativa sobre um determinado assunto.

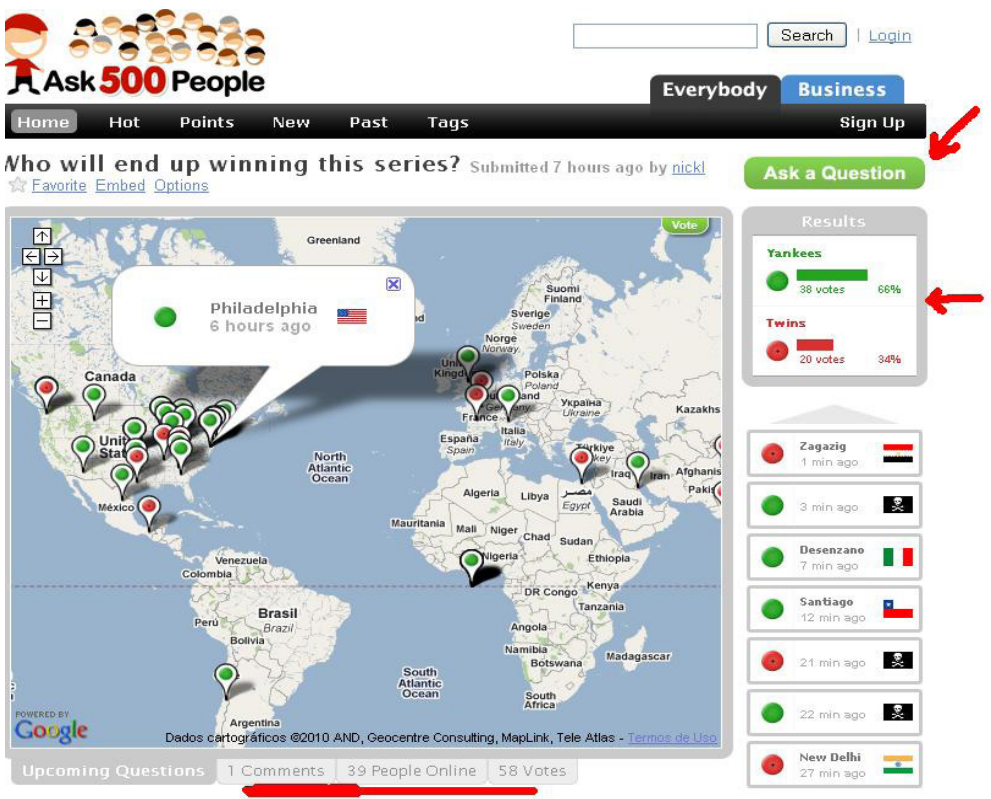

FIGURA 6 - Mashup: o mundo em uma tela FONTE: Disponivel em http://www.ask500people.com/ Acesso em 08 set. 2010

Construído a partir do GoogleMaps ${ }^{9}$, a primeira seta em vermelho apontando para Ask a question formula a pergunta que

9 O GoogleMaps é um serviço disponibilizado gratuitamente de mapas e imagens via satélite. Com resolução de alta definição fica fácil localizar uma rua, uma empresa ou mesmo a melhor rota a tomar em uma viagem. Com uma conta no Google, por exemplo, o usuário pode criar e disponibilizar suas próprias rotas adicionando comentários interessantes a seus seguidores. 
deve ser respondida pelos usuários on-line. Logo abaixo, são apresentados os resultados e na base inferior são apresentados os comentários, quantidade de usuários on-line e número de votantes. Clicando em qualquer local do mashup, o participante é direcionado a outra tela onde novas informações são dadas através de novos feeds de captura de dados na rede.

Nos infográficos de quarta geração é recorrente o uso de textos, sons e imagens estáticas e em movimento, trazendo ao leitor muito mais atenção e interatividade, algo que nesta geração depende muito mais do receptor (BEZERRA, 2010).

O emissor e a mensagem têm maior importância, na primeira fase, àquela que compreende a escolha dos dados a serem representados (sintetização das informações), bem como, a correta escolha de cores, textualização e utilização de símbolos, áudio entre outros. Porém, será o receptor quem vai determinar se as informações postas, da forma como foram disponibilizadas, trarão o resultado esperado pelo emissor (BEZERRA, 2010, p.45-46).

A visualidade do infográfico torna-se relevante no processo de atração do leitor para a informação, porém são as possibilidades e caminhos disponibilizados que terão mais relevância na construção do conhecimento, podendo ser explorados pela Educação a Distância, consolidando não só a modalidade, mas também as possibilidades de interação dos alunos do ensino não presencial com os ambientes virtuais de aprendizagem (AVAs). 


\section{CONSIDERAÇÕES SOBRE A TEMÁTICA}

José Manuel Moran (2000), autor de diversos trabalhos sobre educação a distância, comunicação e mediação pedagógica, é otimista quanto à evolução da EaD no Brasil, bem como sobre a capacidade do público que é atendido por ela. Desde o início da modalidade de ensino com a utilização da correspondência, posteriormente com os telecursos e atualmente com a utilização do meio digital, a sociedade consumidora deixou de ser apenas uma reprodutora de modelos importados começando a dar a sua própria cara a modalidade no Brasil.

São vários os métodos utilizados, mas um chama mais atenção devido ao seu grande papel na capacitação de profissionais a nível técnico. São os telecursos ou teleaulas via satélite que acabam atingindo municípios do Brasil que sequer oferecem o ensino tradicional. Esse tipo de educação acaba se difundindo cada vez mais a partir do momento que os custos com transmissão vêm diminuindo.

Outro modelo também em expansão no Brasil se utiliza de materiais gravados e uma tutoria de apoio. As aulas são gravadas, transformadas em CD-ROOM e os alunos têm, à disposição, tutores presenciais para tirarem suas dúvidas. Esse modelo de transmissão de conteúdos, porém, apresenta falhas pedagógicas uma vez que os professores não estão lado a lado com os tutores generalistas ${ }^{10}$ auxiliando no trabalho acadêmico junto aos alunos. Falta interação.

10 Entende-se por tutor generalista aquele que tem conhecimentos multidisciplinares, podendo, por exemplo, responder questionamentos que não digam diretamente respeito a sua formação acadêmica. Para maiores informações, consultar o artigo $O$ papel do tutor na modalidade de ensino a distância (BEZERRA, 2012). 
O que mais se encontra, nos dias de hoje, são cursos baseados em plataformas virtuais de aprendizagem como o Moodle ${ }^{11}$ ou o Teleduc ${ }^{12}$. O que praticamente se apresenta é um modelo de educação que pode ser definido como semipresencial onde os alunos têm acesso a conteúdos formulados pelo professor da disciplina ou mesmo por um grupo de professores-autores, havendo interação com os tutores que são divididos por grupos de alunos, além de encontros para realização de seminários e provas presenciais. Este, por exemplo, é o modelo adotado pelos cursos na modalidade a distância da Universidade Estadual da Paraíba (UEPB).

Muitos são os suportes que auxiliam no aprendizado virtual. Por um lado, temos os materiais impressos que são os livros-texto, artigos, jornais e revistas e as mídias em geral como o CD e o DVD, além dos ambientes virtuais de aprendizagem (AVAs), teleconferências entre outros. Porém, nada disso faz sentido sem a interação com o professor. O professor "deveria atuar como mediador entre a informação a oferecer e a aprendizagem por parte dos estudantes (GUTIERREZ; PIETRO, 1994, p.62). Na EaD, o professor não é alguém que se encontra presencialmente a qualquer hora; sendo assim, podese dizer que os meios de comunicação devem superar essa ausência. E para tanto devem ser explorados corretamente. E por que não dizer pedagogicamente.

11 Modular Object-Oriented Dynamic Learning Environment é um software livre muito utilizado nas práticas de ensino a distância.

12 [...] desenvolvido no Brasil pelo Núcleo de Informática Aplicada à Educação (Nied) da Unicamp. Sua distribuição é livre e está disponível para download em www.nied. unicamp.br. Seu objetivo é oferecer um ambiente digital que permita ao professor elaborar e acompanhar cursos via web (KENSKI, 2007, p.97). 
Outra dificuldade que se apresenta à EaD é justamente a construção dessa comunicação pelos materiais e meios didáticos disponibilizados pelos ambientes virtuais de aprendizagem. Prova disso é a pouca interação que as imagens, por exemplo, têm quando são inseridas em materiais didáticos, sejam impressos ou mesmo virtuais. Na maioria das vezes, é apenas respaldo para o texto escrito.

Ainda segundo Gutierrez e Pietro (1994), as expressões didáticas são muito rígidas em sua forma e conteúdo. Essa pobreza na produção é o que importa à análise, já que sua utilização, como algo que apenas referenda o texto, não aposta na discussão e elaboração de novos conceitos por parte dos alunos.

A importância da correta utilização de imagem e texto se deve ao fato que, muitas vezes, ela auxiliará na abordagem de um material muito denso e que de certa forma pode desinteressar ao aluno. Ou seja, sua correta relação também vai levar o interesse da temática ao aluno, que a partir da visualização do material passará a se interessar pelo tema e compreendê-lo (GUTIERREZ; PIETRO, 1994).

Para a EaD, a utilização da infografia como "objeto de aprendizagem" pode vir a ser mais uma opção que interaja com alunos tão distantes das salas de aula e do contato com os professores (NUNES, 2007).

Ribas (2005, p.16) aponta que a infografia 'tem a função de facilitar a comunicação, ampliar o potencial de compreensão pelos leitores, permitir uma visão geral dos acontecimentos e detalhar informações menos familiares ao público".

Percebemos com isso que o sujeito, o leitor da informação, está no centro das atenções. E da mesma forma que o aluno da modalidade não presencial, distante no tempo e no espaço necessita de interação, a infografia atua como mediadora desta informação entre o 
meio e o leitor; provando ser assim um elemento necessário à prática de EaD principalmente pela mediação criativa a qual se propõe; além da dinamicidade e atratividade que são características dos infográficos.

Tomando de empréstimo a conceituação de David Willey (2000 apud NUNES, 2007, p.216) de que objetos de aprendizagem são "recursos digitais reutilizáveis e adequados ao uso educacional", o processo de colaboração e cooperação presentes na construção e utilização dos infográficos são práticas possíveis dentro de ambientes gerenciadores de aprendizagem.

Para Nunes (2007), alguns objetos de aprendizagem não necessitam de contextualização, tais como textos, hipertextos, vídeos ou imagens. Mas, por outro lado, identifica como sendo prática de trabalho colaborativo entre os envolvidos e tendo alto potencial educacional, as simulações, que podem ser expressas, por exemplo, nos jogos educativos. Os infográficos apresentam essa mesma característica de simulação da informação.

A leitura sobre a infografia como alternativa para a EaD que apresentamos neste texto, teve como objetivo propor o aprimoramento das metodologias de ensino na modalidade a distância; mas, além disso, apresentar uma ferramenta interativa que ainda não foi utilizada na prática da modalidade. As várias gerações de infográficos apresentadas corroboram a sua empregabilidade na EaD em um processo colaborativo, interativo, ou seja, comunicativo, onde o processo de mediação da metodologia proposta fica evidenciado pela participação de mediadores e mediados

Como ressaltamos no início deste artigo, a Educação a Distância antes de tudo foi entendida como uma ação comunicativa e também como uma prática de formação social, sendo importante na 
consolidação da educação de uma parcela da população que por diversas razões não teve oportunidade de estudar da maneira "tradicional" (especificamente em salas de aula e escolas).

$\mathrm{Na}$ contracorrente da produção massiva das imagens nos veículos de comunicação e possivelmente de educação - pensando na internet e no computador - há a necessidade de reflexão sobre a exclusão que a mesma proporciona, separando os países do hemisfério norte e do sul ${ }^{13}$.

Por outro lado, com todas as possibilidades disponíveis a quem tem acesso à rede mundial de computadores e a educação não presencial, e sendo a infografia um meio proposto pela comunicação como informacional, o importante é tentar viabilizá-la como método auxiliar para a educação, seja nas revistas e jornais on-lines ou nos ambientes virtuais de aprendizagem.

Esperamos com isso que o abismo apontado por Lévy (1999), no que tange as desigualdades entre "os bem-nascidos" e "os excluídos", possa ser minimizado com o acesso aos conteúdos e ferramentas construídas para e disponibilizados pela internet.

A EaD pode ser analisada como um território aberto a novas experiências, sendo essas relacionadas com a interatividade proposta pela internet, como apresentado pelos mashups e newsgames. Construir e compartilhar conhecimento através da infografia se apresenta

13 Esse apontamento pode ser verificado no que diz respeito tanto à produção científica sobre a infografia, bem como, na sua utilização pelos veículos de comunicação. $\mathrm{O}$ Brasil ainda engatinha na utilização da ferramenta e apresenta poucas leituras sobre sua construção e utilização na Educação, enquanto que, em países como Espanha e Estados Unidos, a infografia já se apresenta como prática consolidada. Pierre Lévy, que considera o crescimento do ciberespaço irremediável acrescenta que este "servirá apenas para aumentar ainda mais o abismo entre os bem-nascidos e os excluídos" (LÉVY, 1999, p.12). 
de forma clara e possível para a modalidade e essa era nossa intenção: tornar uma ferramenta de uso jornalístico, da comunicação, em algo possível e prático à construção coletiva em ambientes virtuais de aprendizagem. Referendando, assim, a aprendizagem significativa e a ferramenta como inovadora às práticas de ensino e educação a distância.

\section{REFERENCIAIS}

AMARAL, R. C. G. Limites dos infográficos jornalísticos na Web: sistematização preliminar de características distintivas e produtos semelhantes. In: Congresso Brasileiro de Ciências da Comunicação, n.32., 2009, Curitiba: DT'S - Divisão Temáticas e NP's - Núcleo de Pesquisas, 2009. p.1-14.

ANGELUCCI, B. C. et al. O estado da arte da pesquisa sobre o fracasso escolar (1991-2002): um estudo introdutório. Educação e Pesquisa, v.30, n.1, p.51-72, jan/abr. São Paulo, 2004.

BELLONI, M. L. Educação a distância. 4. ed. Campinas: Autores Associados, 2006.

BEZERRA, C. C. O papel do tutor no ensino a distância. In. OLIANI, G.; MOURA, R. A. (orgs). Educação a distância: gestão e docência. Curitiba: CRV, 2012. p.147-167.

Comunicação e educação: infografia como alternativa para o ensino à distância. 2010. 55f. Monografia (Trabalho de Conclusão de Curso em Novas Tecnologias na Educação) - Universidade Estadual da Paraíba, Campina Grande, 2010. 
GUTIERREZ, F.; PIETRO, D. A mediação pedagógica: educação à distância alternativa. São Paulo: Papirus, 1994.

LÉVY, P. Cibercultura. São Paulo: Ed. 34, 1999.

As tecnologias da inteligência: o futuro do pensamento na era da informática. Rio de Janeiro: Ed. 34, 1993.

KENSKI, V. M. Educação e tecnologias: o novo ritmo da informação. Campinas: Papirus, 2007.

MARCONDES FILHO, C. Comunicação e jornalismo. A saga dos cães perdidos. São Paulo: Hackers Editores, 2000.

MAYER, R. E. The Cambridge Handbook of Multimedia Learning. USA: Cambridge University Press, 2005.

MESSINA, G. Investigación en o investigación acerca de la formación docente: un estado del arte em los noventa. Revista Iberoamericana de Educación, n.19, 1999. p.145-207.

MORAN, J. M. Ensino e aprendizagem inovadores com tecnologias. Informática na Educação: teoria \& prática, v.3, n.1, set. UFRGS. Programa de Pós-Graduação em Informática na Educação, Porto Alegre, 2010, p.137-144.

MORIN, E. A Religação dos saberes: o desafio do século XXI. Rio de Janeiro: Bertrand Brasil, 2001. 
NUNES, C. A. A. O bom uso de objetos de aprendizagem. In: MORAES, U. C. Tecnologia educacional e aprendizagem: o uso dos recursos digitais. São Paulo: Livro Pronto, 2007. p.215-231.

SANCHES, V. La infografía: técnicas, análisis y usos periodísticos. València: Universitat de València; Castello de Olana: Publicaciions de La Universitat Jaume I; Barcelona: Universitat Pompeu Fabra; Bellaterra: Universitat Autònoma de Barcelona: Servei Publiccaions, 2001.

SOUZA, A. M. M.; DESPRESBITERIS, L.; MACHADO, O. T. M. A mediação como princípio educacional: bases teóricas das abordagens de Reuven Feurstein. São Paulo: SENAC, 2004.

\section{REFERÊNCIAS ON-LINE}

ALONSO, J. Grafía. El trabajo em um agencia de prensa especializada em infográficos. In. Revista Latina de Comunicación Social. 1998. Disponível em: http://www.ull.es/publicaciones/latina/a/49inf6. htm>. Acesso em: 3 jul. 2008.

BRASIL. Decreto $\mathrm{n}^{\circ}$ 5.622, de 19 de dezembro de 2005. Regulamenta o art. 80 da Lei no 9.394, de 20 de dezembro de 1996, que estabelece as diretrizes e bases da educação nacional. Disponível em: <http.//www.planalto.gov.br/ccivil_03/_Ato2004-2006/2005/Decreto/D5622.htm>. Acesso em: 03 abr. 2010.

BORRÁS, L.; CARITÁ, M. A. Infototal, inforrelato e infopincel. Nuevas categorias que caracterizan la infografía como ferramenta informativa. In. Revista Latina de Comunicación Social. 2000. Disponí- 
vel em: < http://ull.es/publicaciones/latina/argentina2000/17borras. htm>. Acesso em: 3 jul. 2008.

CEARÁ. Resolução n.0 $\mathbf{3 6 0 / 2 0 0 0}$. Dispõe sobre a utilização dos recursos de educação a distância, no Sistema Estadual de Ensino do Ceará. Disponível em < http://www.ipae.com.br/pub/pt/re/rbead/61/ materia4.htm >. Acesso em: 03 abr. 2010.

RIBAS, B. Ser Infográfico. Apropriações e limites do conceito de infografia no campo do jornalismo. 2005. Disponível em: < http:// www.facom.ufba.br/jol/pdf/2005_ribas_sbpjor_florianopolis_serinfografico.pdf $>$. Acesso em 13 set. 2010.

VELHO, A.P. M. O jornalismo e a infografia dos meios impressos como textos da cultura. BOCC. Biblioteca On-line de Ciências da Comunicação. 2008. Disponível em: < http://www.bocc.uff.br/pag/ bocc-velho-jornalismo-infografia.pdf $>$. Acesso em: 14 mar. 2010. 


\section{OBJETO DE APRENDIZAGEM}

\section{EMPREGADO COMO RECURSO MULTIMÍDIA NA MICROBIOLOGIA}

\section{Karlete Vania Mendes Vieira Robson Pequeno de Sousa}

A Microbiologia é uma ciência que estuda os seres vivos microscópicos, suas características, seus comportamentos e suas aplicações. São muitos detalhes que guardam esses minúsculos seres, para transmitir esses conhecimentos aos alunos de forma dinâmica é necessário utilizar artifícios pedagógicos que promovam uma melhor compreensão e assimilação de um conteúdo tão complexo. Portanto, é fundamental, no mundo informatizado que nos encontramos hoje, tirar o máximo de proveito do arsenal tecnológico que nos é apresentado como, por exemplo, a utilização da multimídia no auxílio da transmissão do conteúdo de forma atrativa e eficaz para o aluno.

O processo de informatização da educação deve ser considerado como meio de ampliação das funções do professor, favorecendo mudanças nas condições e no processo ensino-aprendizagem. Atualmente, os sistemas multimídia interativos assumem importância crescente em todas as áreas da atividade humana que dependem de uma comunicação eficaz, incluindo a educação (RIBEIRO, 2004; MOREIRA, 1986). 
Segundo Ribeiro (2004), os avanços que se verificaram, na última década, nas tecnologias informáticas colocaram o potencial da comunicação multimídia ao alcance de qualquer pessoa: o desenvolvimento de computadores pessoais com um alto poder computacional a baixo custo permite dispor de máquinas capazes de processarem e combinarem na mesma mensagem texto, vídeo, áudio e animação. $\mathrm{E}$ as redes de comunicação são capazes de transferir rapidamente os tipos de informação permitindo comunicar instantaneamente a qualquer lugar do globo. Mas a criação de aplicações multimídia eficazes não é uma atividade que possa ser realizada ao acaso. Para se explorar as potencialidades disponibilizadas pelas tecnologias e sistemas multimídia, não basta utilizar e conhecer as ferramentas de desenvolvimento multimídia é necessário conhecer as características das tecnologias, adequar as combinações de informação visual e auditiva às mensagens que se deseja transmitir e, dotado daquele conhecimento, planejar, antes de desenvolver e produzir uma aplicação multimídia interativa.

A modernização das técnicas de ensino, no entanto, só logrará êxito se utilizada de forma crítica pelos usuários, de modo geral, visto que deverá estar associada a cada realidade educativa e fundamentada em princípios psicopedagógicos que explicitem certa concepção de ensino e aprendizagem. Em termos pedagógicos, podese afirmar que a didática de mídia ainda segue muitos conceitos da tecnologia instrucional e tradicional, visto se basear em psicologia comportamentalista (behaviorista), cujos passos básicos são: a análise de tarefa, o avanço em pequenos e progressivos passos de aprendizagem; a participação ativa do estudante; a velocidade de aprendizagem individual e a realimentação imediata do esforço (MOREIRA, 1986). 
Utilizando a multimídia, podem ser criados vários recursos pedagógicos, como por exemplo, os objetos de aprendizagem (OA) os quais são recursos digitais reutilizáveis e adequados ao uso educacional. Pode ser qualquer material digital, como textos, animação, vídeos, imagens, aplicações, páginas web de forma isolada ou em combinação, com fins educacionais. Trata-se de recursos autônomos, que podem ser utilizados como módulos de um determinado conteúdo ou como um conteúdo completo. São destinados a situações de aprendizagem tanto na modalidade a distância quanto semipresencial ou presencial. Uma das principais características deste recurso é a reusabilidade, ou seja, a possibilidade de serem incorporados a múltiplos aplicativos (WILLEY, 2000; BEHAR et al, 2007).

Os objetos de aprendizagem, como qualquer recurso, podem ser reusados para apoiar a aprendizagem e relaciona-se a materiais educacionais projetados e construídos em pequenos conjuntos com o objetivo de maximizar as situações de aprendizagem em que o OA pode ser utilizado (TAROUCO; FABRE; TAMUSIUNAS, 2003).

Nesse sentido, procurou-se desenvolver e avaliar um objeto de aprendizagem na área de Microbiologia, com recursos multimídia, destinado ao meio acadêmico ligado às ciências da saúde.

\section{INFORMÁTICA E O USO DA TECNOLOGIA NO ENSINO-APRENDIZAGEM}

Os recursos tecnológicos vieram para ficar, não são apenas as grandes corporações que estão cada vez mais investindo em tecnologia para se manter no mercado. Na educação, esta realidade não é diferente, os avanços tecnológicos requerem capacitação e treinamento por parte do docente, e a adequação da instituição ao contexto his- 
tórico, afinal estamos na era da informação, e esta nova geração de educandos buscam suas fontes de saber no mundo virtual da internet. $\mathrm{E}$ assim as diversas formas de aprender e de saber vão se propagando pelo mundo maravilhoso da internet, basta ter um computador e o acesso à internet que o indivíduo passa a deter o poder de consulta às mais variadas fontes de saberes (SOUZA apud MENDES; RUBI, 2010).

Não é segredo que os recursos tecnológicos, há muito tempo, são meios auxiliares entre o educador e o educando, podendo ser utilizados na escola desde o ingresso do educando, bastando apenas que o educador saiba utilizar o software certo na hora certa e com isso proporcionar ao educando a facilidade de absorção de determinados conteúdos, contribuindo para o seu aprendizado, sua formação e no desenvolvimento de suas habilidades e competências (COSTA, 2005).

O educando desta nova era, ao ingressar na faculdade, sua primeira curiosidade não reside mais em saber onde é a biblioteca, mas sim onde se localiza o laboratório de informática, é imperioso que as escolas, universidades e docentes se enquadrem nessas mudanças e lancem mãos dos recursos tecnológicos disponíveis, promovendo as mudanças necessárias que este novo educando requer. O docente desta era não pode ter a visão de que a tecnologia possa ser seu concorrente e sim que as ferramentas tecnológicas podem ajudá-lo a alcançar seus objetivos junto aos educando, pois os vários recursos tecnológicos podem ser utilizados como estratégias de ensino, fazendo com que o ensino-aprendizagem se dê de forma prazerosa, transformando a sala de aula num ambiente em que o tempo não seja o monstro do aluno (SOUZA apud MENDES; RUBI, 2010).

Historicamente, o modelo de ensino superior seguido pelas instituições acadêmicas brasileiras tem se caracterizado pela extrema valorização de aulas teóricas, o que torna o professor o eixo do proces- 
so de aprendizagem e o aluno um coadjuvante, a quem se oferecem informações de natureza conceitual e analítica, prontas e encerradas, existindo pouco espaço e tempo dedicados à descoberta, à criação e, até mesmo, para a reflexão (NUNES apud OKADA et al., 2007).

Há a expectativa de que, uma vez o estudante universitário formado, isto é, concluído o curso de graduação, ele passe a desempenhar uma função profissional e aplique seus conhecimentos, com criticidade e criatividade, no ambiente de trabalho, de forma prática e efetiva. No ambiente de trabalho, um cenário marcadamente empresarial, oo lugar em que o indivíduo de fato se coloca diante da ação, da realidade. O ambiente de trabalho tem, portanto, funcionado como uma extensão da "escola", em que a aprendizagem se completa com as atividades práticas. A empresa, e não a universidade tem sido o espaço da experimentação (OKADA et al, 2007).

Às instituições de ensino, incluindo as de ensino superior, cumpre empregar todos os esforços para que cada estudante possa se desenvolver plena e amplamente nos espaços da escola, diversificando as estratégias de ensino-aprendizagem, com o propósito de possibilitar uma formação integral e que atenda aos reais interesses da sociedade (NUNES apud OKADA et al., 2007).

\section{UTILIZAÇÃO DA TECNOLOGIA DE INFORMAÇÃO COMO FERRAMENTA DE SUPORTE PARA A EDUCAÇÃO DE QUALIDADE}

Acrescentaram-se as tecnologias nas universidades e nas escolas, mas, em geral, para continuar fazendo o de sempre - o professor falando e o aluno ouvindo - com uma capa de modernidade. As tecnologias são utilizadas mais para ilustrar o conteúdo do professor 
do que para criar novos desafios didáticos. Uma das reclamações de escolas e universidades é de que os alunos não aguentam mais nossa forma de dar aula. Os alunos reclamam do tédio de ficar ouvindo um professor falando na frente por horas, da rigidez dos horários, da distância entre o conteúdo das aulas e da vida.

Precisamos repensar todo o processo, reaprender a ensinar, a estar com os alunos, a orientar atividades, a definir o que vale a pena fazer para aprender, juntos ou separados. As tecnologias sozinhas não mudam a escola, mas trazem muitas possibilidades de apoio ao professor e de interação com e entre os alunos (MORAN; MASETO; BEHRENS, 2003).

A educação brasileira teve um grande avanço tecnológico, mas são necessárias algumas transformações no processo educacional para adaptar-se ao mundo atual, que cada vez exige qualidade, para receber o aluno com o novo perfil, porém a busca do conhecimento e capacitação na área tecnológica é uma exigência capaz de interferir na construção social do educando. A sociedade está mudada e o conhecimento adquirido no último século foi equivalente ao obtido durante toda a história da humanidade. Temos que nos adaptar a este dinamismo e termos noção do conhecimento geral acumulado e estarmos aptos para assimilar, em velocidade cada vez maior, conhecimentos importantes para nossas profissões (BARBOSA et al, 2010).

Nesse contexto, a tecnologia da informação e comunicação, vinculada ao processo educacional, estimulam a motivação dos educandos que passam a valorizar seus conhecimentos e produzir melhores resultados escolares. Pois construção do conhecimento é contínuo e interior, estimulado por condições exteriores criadas pelo docente. Por esse motivo, cabe a este o perfil de mediador do processo de interação com ferramentas tecnológicas para preparar suas aulas. 
Os professores deveriam adaptar seus currículos a novas realidades, deveriam usar as mesmas "armas" na transmissão do conhecimento que as mídias e ter um treinamento para tal (ARRUDA, 2004).

É evidente a necessidade de uma formação e qualificação técnica e prática que são habilidades e competências essenciais à formação dos docentes na atualidade. A tecnologia da informação é um desafio a ser vencido, é preciso que os professores tenham formação didática pedagógica, sabendo utilizar novas tecnologias da comunicação para oferecer aos educandos o conhecimento que eles precisam para que possam acompanhar a velocidade das transformações educacionais, sociais, políticas e econômicas (MENDES; RUBI, 2010).

Em vez disso, chegamos a um modelo de escola no qual os professores passam quase todo tempo dentro de salas de aula aplicando conhecimentos adquiridos, há muito tempo, e poucas vezes atualizados ou reciclados, deixando claro que um dos setores menos sensíveis ao desenvolvimento tecnológico desta sociedade é o sistema educacional. Para adaptar a educação ao mundo atual, é necessário educar para compreender melhor seu significado dentro da nossa sociedade, ajudando na sua democratização, onde cada pessoa possa exercer integralmente sua cidadania (LUCENA; FUKS, 2000).

\section{MULTIMÍDIA E EDUCAÇÃO}

As tecnologias multimídia podem ser encaradas como ferramentas que auxiliam o utilizador na divulgação de ideias, conceitos ou serviços. A forma mais comum de utilizar as tecnologias multimídia é através das aplicações multimídia, que na sua grande maioria são interativas, pois permitem que os conteúdos sejam apresentados 
de uma forma não linear em que o utilizador desempenha um papel ativo (RIBEIRO, 2004).

É possível classificar as aplicações multimídia de acordo com vários critérios, por exemplo, quanto ao tipo de utilizador, quanto ao mercado a que se destinam ou quanto à área de utilização (área de atividade humana). Quanto ao tipo de utilizador, podem, por exemplo, classificar-se em aplicações para crianças e aplicações para adultos, ou em aplicações para alunos e aplicações para professores. Se classificarmos as aplicações multimídia quanto ao mercado a que se destinam, já é possível definir classes diferentes, tais como o mercado doméstico, o mercado profissional, o mercado educativo e a administração pública.

A multimídia é uma ferramenta muito importante na comunicação e sua eficácia no aspecto educacional já está consagrada, pois possibilita a combinação das várias formas de mídia e da interatividade que ela proporciona e promove o desenvolvimento e percepção do aprendizado (BUGAY; ULBRICHT, 2000). A forma de ensinar e aprender através da multimídia é um desafio extremamente motivador, que implica em trabalhos de investigação voltados para a produção de meios e materiais e para a teorização a respeito de sua aplicação em relações educativas mediadas por esta tecnologia. A multimídia pode contribuir para um avanço qualitativo no processo de ensino -aprendizagem, pois melhora o interesse e a atenção do aluno e provoca uma melhor retenção da informação (VALENTE, 2002).

Afirma Guerra (2001) que como a multimídia ativa vários sentidos, simultaneamente, torna a informação mais redundante, oferecendo um maior poder de assimilação, além de aumentar a atenção haja vista que os apelos sensoriais são multiplicados. A multimídia é um recurso que parece ter uma vocação natural para a educação, 
uma interface multimídia bem projetada pode enriquecer o ambiente de aprendizagem e permitir que o aluno participe da construção do seu conhecimento.

\section{APRENDIZAGEM MULTIMÍDIA}

Segundo Mayer (2009), a aprendizagem multimídia ocorre quando as pessoas projetam a construção do conhecimento através da representação mental de palavras e imagens, pois elas aprendem melhor com palavras e imagens do que apenas com palavras. Ele ainda cita alguns princípios que norteiam a aprendizagem multimídia, são eles: a) O Princípio Multimídia: fala exatamente o que foi descrito acima, onde as pessoas aprendem melhor quando combinam palavras e imagens do que só palavras; b) Proximidade espacial: as palavras e imagens devem estar próximas em vez de afastadas; c) Proximidade temporal: as palavras e imagens são apresentadas simultaneamente em vez de sequencialmente; d) Coerência: se as palavras e imagens não são importantes para o tema devem ser excluídas da apresentação multimídia; e) Modalidade: utiliza animação e narração em vez de animação e texto escrito; f) Redundância: aponta maior aprendizagem através da animação e narração do que a aprendizagem através da animação, narração e texto.

\section{OBJETO DE APRENDIZAGEM COMO INSTRUMENTO DE ENSINO-APRENDIZAGEM}

Segundo Willey (2000), os objetos de aprendizagem são recursos digitais reutilizáveis e adequados ao uso educacional. Num contexto mais atual, Behar et al (2007) definem objeto de aprendiza- 
gem como qualquer material digital, como textos, animação, vídeos, imagens, aplicações, páginas web de forma isolada ou em combinação, com fins educacionais. Trata-se de recursos autônomos, que podem ser utilizados como módulos de um determinado conteúdo ou como um conteúdo completo. São destinados a situações de aprendizagem tanto na modalidade a distância quanto semipresencial ou presencial. Uma das principais características deste recurso é a reusabilidade, ou seja, a possibilidade de serem incorporados a múltiplos aplicativos. Um mesmo objeto pode ter diferentes usos, seu conteúdo pode ser reestruturado ou reagregado, e ainda ter uma interface modificada para ser adaptada a outros módulos. Todas essas ações podem ocorrer de forma independente ou conciliada com outros objetos, considerando sempre os objetos a serem alcançados com o público alvo de (re) utilização do OA.

Os autores Tarouco; Fabre; Tamusiunas (2003) complementam definindo os objetos educacionais ou objetos de aprendizagem como qualquer recurso, suplementar ao processo de aprendizagem, que pode ser reusado para apoiar a aprendizagem. Dessa forma, a expressão "objeto educacional"relaciona-se a materiais educacionais projetados e construídos em pequenos conjuntos com o objetivo de maximizar as situações de aprendizagem em que o OA pode ser utilizado.

Betio; Martins (2004), Tarouco; Fabre; Tamusiunas (2003) ressaltam que a reusabilidade não é a única característica de um objeto. Destacam-se também acessibilidade, interoperabilidade, durabilidade e customização. A acessibilidade corresponde à possibilidade de acesso remoto aos recursos educacionais através de um repositório. A interoperabilidade potencializa a reutilização dos objetos, na medida em que visa à articulação/comunicação de materiais em diferentes 
plataformas e ferramentas. Já o critério de durabilidade aponta para a garantia do uso do recurso educacional, mesmo quando a base tecnológica em que ele foi desenvolvido sofreu mudanças. Tais considerações evitam a reconstrução ou a reprogramação do objeto em questão. E finalmente, a customização refere-se à flexibilidade e à adaptação do material a diferentes níveis de ensino, incluindo nessa perspectiva a construção de novos conteúdos a partir da base que compõe o projeto inicial.

Os repositórios são espaços remotos onde os objetos são armazenados, obedecendo a uma lógica de identificação para que ele possa ser localizado a partir de buscas por tema, nível de dificuldade, autor ou pela relação com demais objetos. Os repositórios de objetos de aprendizagem, como a Coletânea de Entidades de Suporte ao uso de Tecnologia na Aprendizagem (CESTA) ${ }^{1}$, são sistemas de catalogação que permitem a publicação e a reutilização desses OAs por parte de qualquer usuário em qualquer curso. Também possibilitam a utilização dos objetos como fonte de pesquisa e de referência para que outros educadores organizem suas aulas, disponibilizem aos alunos ou os avaliem.

Alguns tipos de objetos de aprendizagem são bastante óbvios e não necessitam de maiores esclarecimentos como textos, hipertextos, vídeos, imagens. Contudo, há uma categoria de objetos que tem um potencial educacional extremamente rico e diversificado: as simulações (por exemplo, jogos interativos). Nesse caso, é interessante pensar que em alguns momentos é o uso do objeto - os parâmetros testados, as decisões tomadas, as configurações feitas, etc. - que demonstra o processo de aprendizagem e o domínio sobre certo assunto (OKADA et al, 2007).

1 Disponível em: http//www.cinted.ufrgs.br/CESTA/ 
Existem diversos tipos de objetos de aprendizagem. Em geral, quem cria um objeto tem alguma finalidade em mente e alguma concepção de ensino-aprendizagem. A finalidade pode ser a de introduzir um assunto de maneira contextualizada, de criar uma oportunidade para o uso de um conhecimento já adquirido, de demonstrar algum conceito complexo, de ressaltar interligações entre vários conceitos, de induzir certo tipo de pensamento ou comportamento no usuário, de ajudar num processo de educação, de avaliar o grau de conhecimento do usuário sobre certo assunto ou habilidade, etc. A maneira como isso é feito depende da concepção de ensino e aprendizagem de quem o criou: o aluno pode vir mais ou menos organizado e estruturado, a navegação pode ser obrigatória ou optativa, pode ser linear ou ter níveis de complexidade para satisfazer diferentes tipos de público, pode ou não estimular a metacognição, etc. (OKADA et al, 2007).

Um professor que escolhe um objeto para usar como estratégia de ensino e aprendizagem deve ter em mente a finalidade para a qual ele foi proposto e qual o estágio de desenvolvimento de seus alunos. O professor tem ou deveria ter o papel de arquiteto e designer da aprendizagem. É ele quem consegue criar caminhos cognitivos interessantes, desafiadores e significativos para seus alunos. Uma boa oferta de recursos educacionais - objetos de aprendizagem, especialistas, excursões a campo, experiências em laboratório, etc. - permite a criação desses caminhos segundo a visão educacional do professor. Alguns autores têm obtido sucesso em suas pesquisas com aplicações de objetos de aprendizagem utilizando a multimídia em diferentes áreas, na Geografia e Matemática, Soares (2008) desenvolveu um software educacional para ser utilizado no ensino-aprendizado em topografia e obteve êxito em sua aplicação, levando os alunos a com- 
preenderem melhor o conteúdo antes tão distante da realidade dos mesmos. Na área de saúde Illera (apud Mishra, Sharma, 2005) cita em seu estudo o uso de um software na área de saúde, onde desenvolveu um CD com informações sobre a AIDS como o que é, como se adquire, quais os riscos e como as pessoas devem se prevenir, os alunos tiveram ótimo rendimento no aprendizado. Zem-Mascarenhas e Cassiani (2001) também avaliaram um software educacional para o ensino de enfermagem pediátrica, a maioria dos alunos avaliou de forma positiva tal objeto de aprendizagem. Na área de Engenharia Civil, Assis (2002) encontrou satisfação dos alunos quando utilizou os recursos multimídia no ensino de estruturas de concreto armado e protendido.

\section{ASPECTOS RELEVANTES PARA O DESENVOLVIMENTO DE OBJETOS DE APRENDIZAGEM}

Considerando as características pertinentes aos OAs, notase que o planejamento e a construção deles podem requerer do autor a apropriação de temas de diferentes áreas do conhecimento. Assim, considera-se relevante a formação de um grupo interdisciplinar para construção de um material educacional digital que alcance as características pertinentes ao objeto. A troca de ideias e de informações e o confronto de diferentes perspectivas acerca da construção do material são as principais vantagens de um trabalho cooperativo coeso e consistente. Para o desenvolvimento de um material de boa qualidade, é necessário ter conhecimento de usabilidade, interface, linguagem de programação/softwares que permitam a implementação do material e a publicação em repositórios quando for o caso. Também é necessário ter noções precisas do conteúdo em si para poder elaborar o material 
de apoio e as atividades propostas. O ideal é contar com uma equipe interdisciplinar (BEHAR et al, 2009).

Afirmam Betio, Martins (2004); Prata; Nascimento (2007), Silva; Fernandes (2007); Tarouco; Fabre; Tamusiunas (2003) que o educador precisa estar atento a alguns aspectos relevantes ao desenvolverem um OA;

Primeiro, os professores devem conhecer muito bem os conteúdos a serem apresentados, pois, caso contrário, podem permitir que conceitos errôneos estejam presentes no material, ou possam dar margem a interpretações que não estejam de acordo com o mundo real. Esses desvios podem ser derivados de uma programação não estruturada ou de definições empíricas do próprio programador, quando o professor não estiver executando essa função.

O professor deve conhecer as possibilidades ou recursos de programação, pois o objeto deve atender ao modelo pedagógico teorizado pelo educador; pois de nada vale desenvolver um objeto que não contemple os ideais propostos.

O professor deve também ter conhecimentos sobre o potencial do aplicativo escolhido para desenvolver o objeto, pois este pode permitir a implantação de recursos que modelem a teoria pedagógica, mas não atendam as necessidades totais dos educandos. Os estudos sobre a modelagem de um OA devem envolver um grupo inter e multi disciplinar que possa realmente colaborar na construção de um objeto robusto em termos de operacionalidade, flexível em ambientes, consistente em conteúdos aplicáveis às teorias educacionais subjacentes, adaptável às dos alunos.

O professor deve ser conhecedor das condições de aprendizagem de seus alunos, dos níveis de conhecimentos já adquiridos 
sobre o tema a ser desenvolvido e do uso de recursos computacionais, além de condições socioeconômicas e culturais.

Destaca-se ainda que, para o desenvolvimento de OAs, é importante considerar tanto os aspectos educacionais quanto estéticos e tecnológicos. Dessa forma, partindo da análise dos aspectos já mencionados, busca-se oferecer ao usuário OA de fácil navegação e agradável experiência estética de forma que os anseios educacionais possam ser atendidos.

O modelo para o planejamento sistemático de projeto multimídia baseia-se no princípio DDD-E segundo Ivers e Barron (2006) que consiste nas etapas Decide, Design, Development e Evaluate, onde a primeira etapa Decide determina a meta do projeto, desenvolve o Brainstorm "mapa conceitual", realiza a pesquisa e planeja as atividades para professores e alunos; Design: determina a estrutura do programa e sua implementação, desenhando os fluxogramas, projetando as telas específicas e criando os "storyboards"; a etapa de Develop: cria elementos de mídia, coleta e facilita a lição através do áudio, vídeo, gráficos, animações, programas de autoria; e por fim a fase Evaluate (avaliação): reflete sobre o projeto, perspectiva futura e desempenho do aluno, necessária para validação da aplicação educativa.

\section{O PERCURSO: OBJETO DE APRENDIZAGEM NO ENSINO DA MICROBIOLOGIA}

A presente pesquisa propôs melhorar a aprendizagem do conteúdo de Genética bacteriana com uma turma de alunos que cursaram o segundo ano de Odontologia da Universidade Estadual da Paraíba, durante os períodos de 2010.1 e 2010.2, através da aplicação de um Objeto de Aprendizagem. A turma era composta de dezesseis 
(16) alunos, todos cursaram a disciplina de Microbiologia Básica no período 2010.1. Entretanto, a análise final foi realizada com catorze (14) alunos, ou seja, aqueles que compareceram para a aplicação e avaliação do Objeto de Aprendizagem (OA).

O desenvolvimento do OA com os tópicos considerados básicos para entendimento do conteúdo foi baseado nos princípios da multimídia, seguindo o modelo para projetos multimídia na educação, o DDD-E(Decide, Design, Develop, Evaluate).

A primeira fase - Decide - que se refere à fase inicial do desenvolvimento, foi composta do Mapa Conceitual do conteúdo com os principais pontos teóricos a serem abordados durante o OA.

A segunda fase - Design - esteve relacionada com o conteúdo, e a estruturação inicial da aplicação foi elaborada através do Mapa Navegacional, do Mapa de Cenário e do Roteiro lógico do conteúdo a ser seguido. O Mapa Navegacional apresentou como seria a sequência dos pontos teóricos ao longo do OA, divididos em Telas, e o Mapa de Cenário, o ambiente ilustrativo, onde acontece toda apresentação do OA.

Na terceira fase - Develop - que se referiu ao desenvolvimento propriamente dito do OA, foram utilizados alguns softwares do tipo proprietários e outros livres, nesse sentido, utilizou-se um software para animação: Macromedia Flash (proprietário); um software de edição de imagens: Gimp (livre); três softwares de edição de áudio: Audacity; DVDVideoSoft Free Studio, AVIReComp (ambos softwares freeware); além de um software de conversão e download de vídeos: Atube Catcher (totalmente freeware). Esta fase foi desenvolvida por um aluno do último ano de Licenciatura da Computação da Universidade Estadual da Paraíba.

A última fase - Evaluate - fase de avaliação foi realizada após confecção, revisão e teste do OA o qual foi aplicado no final do 
período 2010.2, em sala de aula, e exposto em datashow para todos os alunos de uma única vez no horário de duas aulas consecutivas. O conteúdo do OA foi dividido em três etapas, após cada etapa, havia um exercício relacionado, totalizando três exercícios. Ao final do OA, foram aplicados dois questionários para avaliação do mesmo.

Foram aplicados três exercícios, os quais foram respondidos sequencialmente, no momento em que os mesmos iam sendo apresentados durante o decorrer do OA. Cada aluno recebeu as mesmas questões apresentadas no OA de forma digitadas e impressas, as quais eram respondidas imediatamente à sua exposição no datashow durante a apresentação do OA, o objetivo destes exercícios foi saber se estava havendo assimilação imediata do conteúdo apresentado. Ao final da apresentação do OA, dois tipos de questionários foram aplicados aos alunos com a finalidade de avaliar a função educacional do OA e sua diferença com relação à aula convencional.

Para análise geral, foram utilizadas as notas atribuídas a cada resposta da escala de Likert, onde as mesmas variaram de 1 a 5 . A partir dessas notas, foi determinada a média dos pontos, conforme metodologia descrita por Berenson e Levine (1992), a qual foi adaptada para a seguinte fórmula:

$$
M P=\frac{(P 1 . N a)+(P 2 . N a)+(P 3 . N a)+(P 4 . N a)+(P 5 . N a)}{N T a}
$$

Em que:

MP: Média dos pontos

P1, P2, P3, P4 e P5: Pontos referentes às notas atribuídas às respostas da escala de Likert, ou seja, 1, 2, 3, 4 e 5, respectivamente.

Na: Número de alunos que atribuíram cada ponto individualmente da escala de Likert.

NTa: Número total de alunos envolvidos na pesquisa. 


\section{APRESENTAÇÃO DOS RESULTADOS}

O primeiro módulo do OA foi relacionado aos constituintes básicos da genética bacteriana; ao seu término, foram aplicadas quatro questões. Conforme os resultados da Figura 1, percebe-se que a maioria deles (64\% ) acertou todas as questões apresentadas no OA e $29 \%$ só erraram apenas uma questão, isso indica que houve boa assimilação do conteúdo inicial por parte dos alunos. Esse dado é importante, haja vista que o entendimento desse conteúdo é fundamental para compreender os demais conteúdos apresentados nos módulos seguintes.

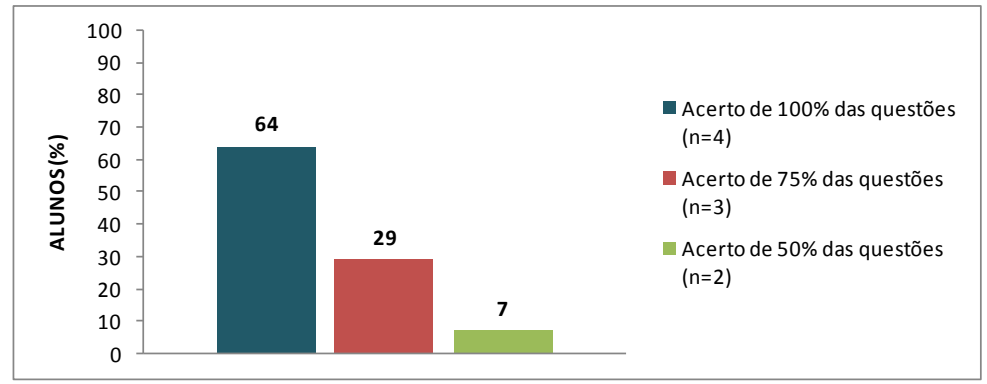

FIGURA 1 - Percentual de acerto nas quatro questões aplicadas ao final do primeiro módulo do $\mathrm{OA}$

FONTE - Os autores

O segundo módulo abordou a síntese protéica, as etapas necessárias para que uma proteína seja formada no interior da bactéria e como essas etapas acontecem. O segundo questionário foi composto de cinco questões e o percentual de acerto das mesmas pelos alunos está apresentado na Figura 2. Igualmente ao primeiro módulo, o número percentual de alunos que acertaram todas as questões foi $64 \%$ e o percentual restante errou apenas uma questão, indicando um aprendizado satisfatório do conteúdo abordado. 


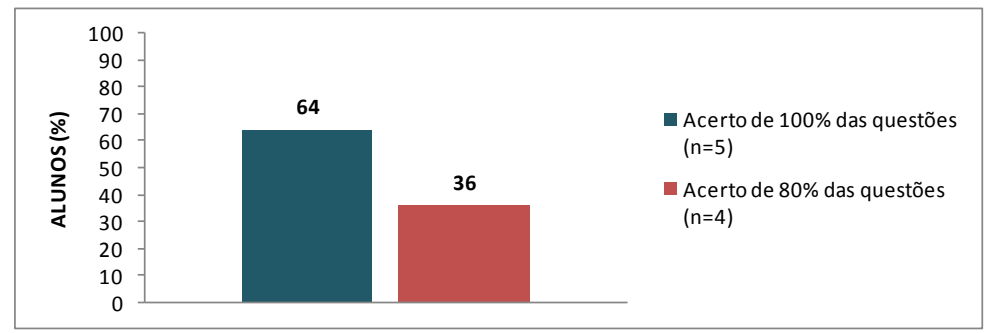

FIGURA 2 - Percentual de acerto nas cinco questões aplicadas ao final do segundo módulo do OA

FONTE - Os autores

Finalmente, foi avaliado o último módulo, este com um conteúdo mais extenso e complexo que envolve os mecanismos de transferência de genes entre as bactérias. Foram apresentadas quatro questões e os percentuais de acerto das mesmas pelos alunos encontram-se na Figura 3. Apesar da complexidade e da quantidade de conteúdo, o percentual de alunos que acertaram todas as questões foi o maior encontrado com aproximadamente $80 \%$. Este dado tem relevância haja vista que esse assunto é de difícil compreensão por parte dos alunos, quando ministrado através de aulas convencionais apontando uma eficácia deste $\mathrm{OA}$ provavelmente pela forma didática atrativa e interativa em que é apresentado, principalmente pela presença das ilustrações, dos vídeos e dos exercícios. 


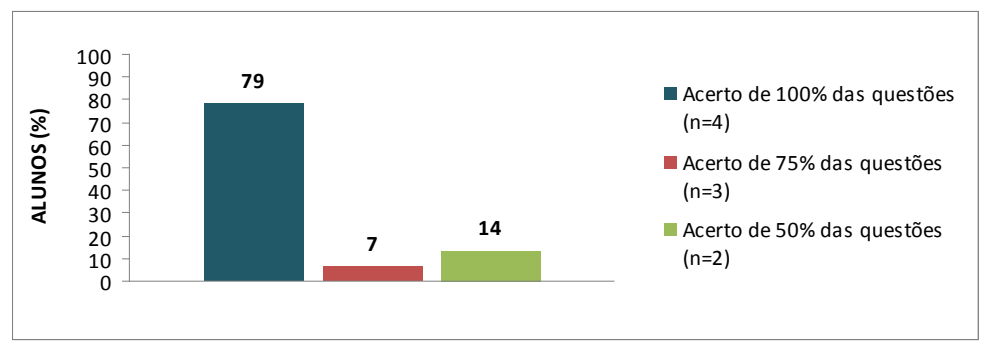

FIGURA 3 - Percentual de acerto nas quatro questões aplicadas ao final do terceiro módulo do OA

FONTE - Os autores

\section{RESULTADOS DAS AVALIAÇÕES SOBRE O OBJETO DE APRENDIZAGEM}

Inicialmente, gostaríamos de saber se o OA apresentou uma maior interação com o aluno do que a aula expositiva convencional e a grande maioria (57\% ) concordou plenamente com essa afirmativa (Figura 4). Quando calculados os pontos, verificou-se que os alunos atribuíram um valor de 4,4 para essa variável. Dentre as diferentes concepções que visam interpretar o funcionamento da aprendizagem do homem, Fenner (2000) cita a concepção interacionista, segundo a qual, o homem constrói seus conhecimentos pela constante interação com o meio, combinando sua aptidão inata de aprender com os estímulos de realimentação, recebidos do meio ambiente onde realiza suas experiências, visando a sua sobrevivência. Dessa forma, quanto maior a interação com o material multimídia disponível, maior e melhor será o aprendizado do aluno ou do professor. 


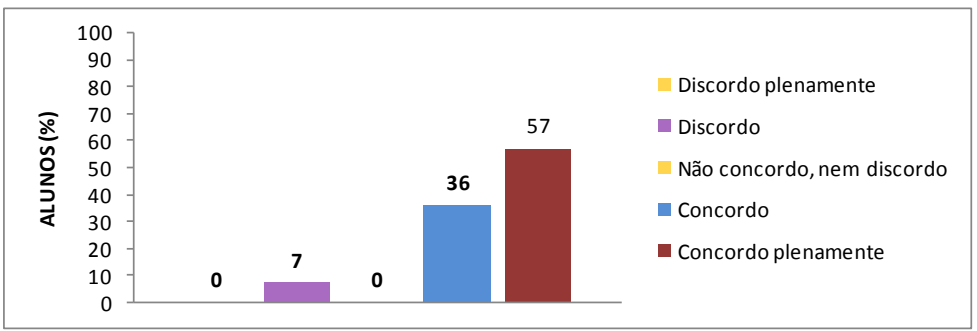

FIGURA 4 - Avaliação quanto ao OA apresentar melhor interação com o aluno do que a aula expositiva convencional

FONTE - Os autores

A maioria dos alunos (72\% ) concordou plenamente que o OA foi mais didático do que a aula convencional, embora pequeno percentual discordou ( $14 \%$ ) ou discordou plenamente (7\% ) conforme apresenta a Figura 5. O total de pontos atingidos foi de 4,2. As vantagens da multimídia estão incentivando o desenvolvimento de sistemas ou aplicações multimídia voltados para o ensino. Porém, cabe salientar que cada mídia é mais adequada para transmitir um tipo de informação; assim, como a multimídia trabalha com um conjunto delas, há uma sinergia no sentido de que uma mídia complementa a outra no processo de transmissão de informação (GUERRA, 2001).

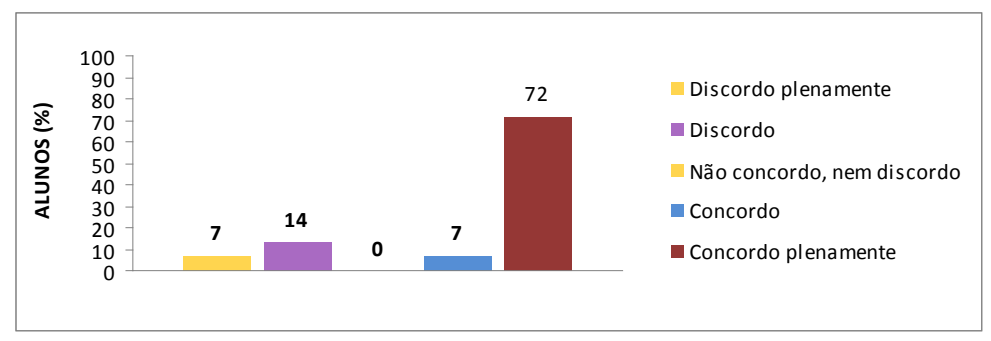

FIGURA 5 - Avaliação quanto ao OA ser mais didático do que a aula expositiva convencional

FONTE - Os autores 
A Figura 6 apresenta, de forma clara, que a grande maioria $(79 \%$ ) dos alunos concordou plenamente que as animações gráficas proporcionaram um melhor entendimento do conteúdo quando comparado com a aula expositiva convencional. Neste parâmetro, o total de pontos foi 4,7. Este dado apresenta a importância do vídeo no processo de ensino-aprendizagem haja vista que este meio multimídia é capaz de acionar sentidos do nosso corpo, como a visão e audição, interligando-os com o movimento das imagens, tornando a aula mais atrativa e dinâmica. Nascimento e Bastos (1996) afirmam que ao misturar o aspecto interativo do computador com o poder audiovisual dos vídeos, a multimídia torna-se um poderoso método de comunicação que possibilita ao professor atingir seus objetivos junto aos alunos, de maneira atrativa e eficaz, despertando maior interesse e motivação.

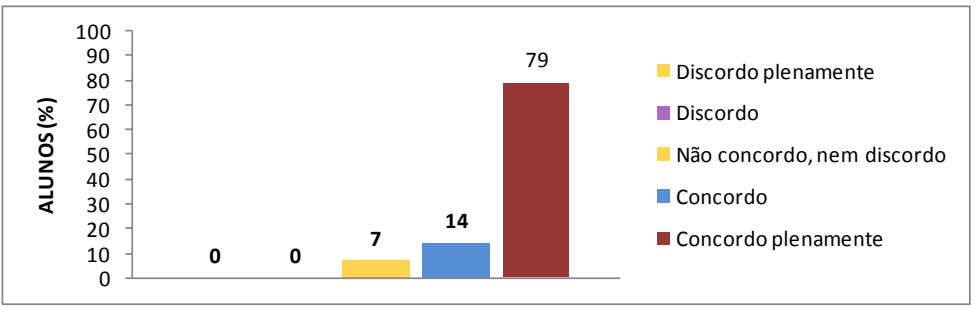

FIGURA 6 - Avaliação quanto às animações gráficas do OA proporcionarem melhor compreensão do conteúdo do que a aula expositiva convenciona FONTE - Os autores

Quanto ao aprendizado, 50\% dos alunos concordam plenamente que o mesmo foi mais rápido com o uso do $\mathrm{OA}$ em comparação com aquele obtido na aula convencional, um total de $36 \%$ concorda com essa afirmativa e $14 \%$ não concordam nem discordam. Os resultados estão apresentados na Figura 7. Essa rapidez de aprendizado com o OA recebeu uma avaliação de 4,4 pontos de acordo com a escala 
de Likert. Os dados de Soares (2008) concordam tanto no percentual quanto na pontuação no que se refere a esse item.

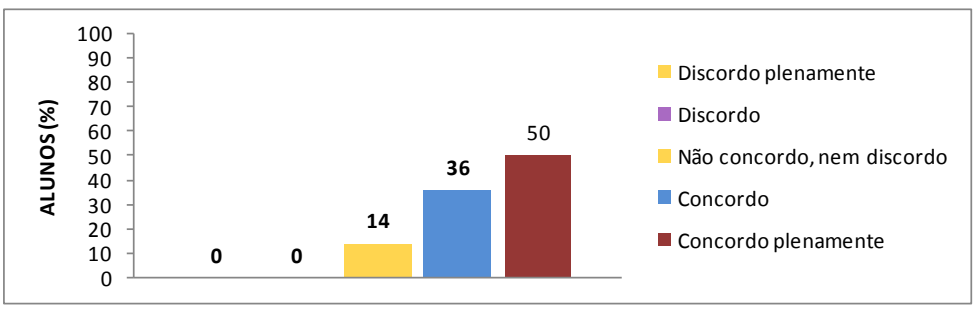

FIGURA 7 - Avaliação quanto ao aprendizado ser mais rápido com o OA quando comparado à aula expositiva convencional FONTE - Os autores

A maioria dos alunos (64\% ) concorda plenamente que a aula teórica de Microbiologia referente ao assunto Genética Bacteriana se tornou mais atrativa com o OA (Figura 8). Verificou-se um total de 4,6 pontos para essa característica.

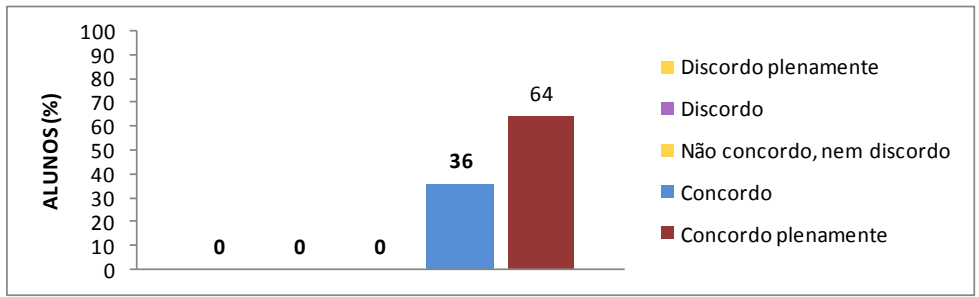

FIGURA 8 - Avaliação quanto ao OA tornar as aulas teóricas mais atrativas FONTE - Os autores

Com relação à afirmativa de que o OA é suficiente para substituir a aula, houve diversidade de opiniões. Porém $43 \%$ dos alunos concordam plenamente com essa afirmativa, $29 \%$ apenas concor- 
dam, 7\% não concordam nem discordam e 21\% discordam(Figura 9). Neste quesito, foi verificada uma nota de 3,9 pontos.

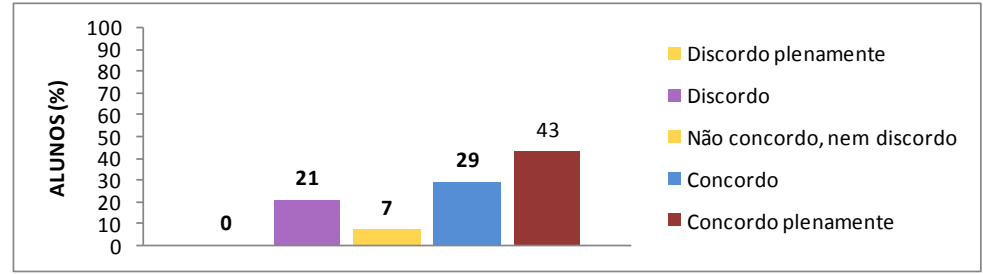

FIGURA 9 - Avaliação quanto ao OA ser suficiente para substituir a aula expositiva convencional

FONTE - Os autores

\section{CONSIDERAÇÕES FINAIS}

Por ser um poderoso método de comunicação, a multimídia tem possibilitado ao professor atingir seus objetivos de ensino junto aos alunos, de maneira eficaz e atrativa, despertando maior interesse e motivação. Baseado nos resultados obtidos, segundo avaliação dos estudantes, pode-se afirmar que o sistema multimídia aqui avaliado pode ser utilizado como recurso didático no ensino e aprendizado da Microbiologia, de maneira satisfatória.

O Objeto de Aprendizagem aplicado também demonstrou proporcionar uma boa assimilação do conteúdo através dos índices de acertos observados nos exercícios aplicados após cada módulo.

A utilização desse tipo de recurso computacional, como ferramenta de auxílio no processo ensino-aprendizagem e sua implementação nos vários segmentos educacionais, inclusive no ensino superior, vem tornando-se necessária para atrair a atenção dos alunos 
e os tornarem mais motivados a aprenderem determinados conteúdos que, por vezes, são enfadonhos e de difícil entendimento.

\section{REFERENCIAS}

ARRUDA, E. Ciberprofessor: novas tecnologias, ensino e trabalho docente. Belo Horizonte: Autêntica, 2004.

ASSIS, W. S. Utilização de recursos multimídia no ensino de concreto armado e protendido. 2002. São Paulo-SP. Dissertação de Mestrado em Engenharia, 121p. Escola politécnica da Universidade de São Paulo.

BUGAY, E. L.; ULBRICHIT, V. R. Hipermídia. São Paulo: Visual Books, 2000.

COSTA, C. Educação, imagem e média. São Paulo: Cortez, 2005.

GUERRA, J.H.L. Utilização do computador no processo de ensino-aprendizagem: uma ampliação em planejamento e controle de produção. 159f. Dissertação (Mestrado em Engenharia de Produção). Universidade de São Paulo, São Carlos, 2001.

ILLERA, J. R. Interactive multimídia and AIDS prevention: A case study. In. MISHRA, S; SHARMA, R. C. Interactive multimedia in education and training. Hershey, PA: Idea Group, 2005, pp.271-288.

IVERS, K. S.; BARRON, A. E. Multimedia Projects In Education: designing, producing and Assessing. Third Edition, USA: Libraries. 
LUCENA, C.; FUKS, H. A educação na era da internet. Rio de Janeiro: Clube do Futuro, 2000.

MENDES, M.; RUBI, R. C. Internet, multimídia \& educação. Pará de Minas, MG: Virtualbooks, 2010.

MORAN, J. M.; MASETTO, M.; BEHRENS, M. Novas tecnologias e mediação pedagógica. 7. ed. São Paulo-SP: Papirus, 2003.

MOREIRA, M. O uso do computador na Educação: pressupostos psicopedagógicos. Educação em Revista, n.4, p.13-17. Belo Horizonte, 1986.

OKADA, A. L. P. et. al. Tecnologia educacional e aprendizagem: o uso dos recursos digitais. São Paulo: Livro Pronto, 2007.

RIBEIRO, N. Multimédia e tecnologias interactivas. Lisboa: FCA Editora de Informática, 2004.

SOARES, C.S. Desenvolvimento e avaliação de sistema multimídia para o ensino e aprendizagem em topografia. 39f. Monografia (Especialização em Novas Tecnologias na Educação). Universidade Estadual da Paraíba, Campina Grande, 2008.

ZEM-MASCARENHAS, S. H; CASSIANI, S. H. B. Desenvolvimento e avaliação de um software educacional para o desenvolvimento de enfermagem pediátrica. Revista Latino-Am. Enfermagem, v.9, n.6, p.13-18, 2001. 
WILLEY, D. A. Connecting learning objects to instructional design theory: A definition, a metaphor, and a taxonomy. Digital Learning Environments Research Group, 2000. 


\title{
O USO DO LABORATÓRIO DE
} INFORMÁTICA EDUCACIONAL: PARTILHANDO
VIVÊNCIAS DO COTIDIANO ESCOLAR

\author{
Luzivone Lopes Gomes \\ Filomena $M^{a}$ Gonçalves da Silva Cordeiro Moita
}

\section{INTRODUÇÃO}

As tecnologias digitais contribuem para reinventar o processo de ensino e aprendizagem, os diversos suportes tecnológicos precisam fazer parte do contexto escolar, e os professores precisam explorá-los de forma crítica e contextualizada. Nesse sentido, é necessário se desenvolverem pesquisas, com o objetivo de se compreender como estão sendo utilizadas as tecnologias digitais no contexto escolar para a melhoria da qualidade do ensino e da aprendizagem, tendo em vista uma formação de sujeitos atuantes na sociedade contemporânea.

Delimitamos este estudo a partir da reflexão sobre a importância da utilização das tecnologias digitais no contexto escolar, destacando-se a investigação do uso do Laboratório de Informática pelos professores na Educação Básica em uma escola da rede privada de ensino de Campina Grande/PB, porquanto, em um contexto, que as mudanças tecnológicas ocorrem através de segundos, os questionamentos sobre como utilizar, interpretar e fazer escolhas de suportes 
tecnológicos é uma das grandes questões no processo da inserção das tecnologias digitais na prática educativa.

Dessa forma, compreendemos que os professores precisam ter um olhar reflexivo nas transformações culturais e tecnológicas e lançarem-se ao desafio de práticas educativas inovadoras, pois inserir novas metodologias a partir de contextos digitais na prática educativa é uma atitude que todos os professores precisam adotar para fazer parte de um processo complexo de mudança na sociedade contemporânea (MORAES, 2011).

Nessa perspectiva, este estudo está apoiado em reflexões sobre a importância do uso das tecnologias no contexto escolar e fundamentado nos estudos dos seguintes autores: Valente (2010, 2006, 1999); Moran (2010); Lévy (1996); Tardif (2011); Morin (2006); Moraes (2008; 1997); Baumam (2010); Lopes (2010); Neto (2006), entre outros que consideram as tecnologias na educação como grande aliadas do desenvolvimento cognitivo, da inovação do ensino e como recurso potencializador de novos textos e novas formas de pensar.

Estes escritos estão organizados em três momentos: tecnologia e educação, informática educacional e formação e saberes docentes.

Adotamos para esta pesquisa uma metodologia qualitativa, de cunho descritivo, por ser útil a nossa abordagem. Utilizamos, como técnica, entrevista semiestruturada e observação participante e sistemática no laboratório de Informática, com o objetivo de verificar de que forma os professores estão propondo as atividades no Laboratório de Informática, buscando compreender a inter-relação dos fatos, pois, de acordo com Chizotti (2001, p.79), “o sujeito-observador é parte integrante do processo de conhecimento e interpreta os fenômenos, atribuindo-lhes um significado, e o objeto não é um dado inerte e neu- 
tro; está possuído de significados e relações que os sujeitos concretos criam em suas ações”.

Os sujeitos da pesquisa são professores da Educação Básica de uma escola da rede privada de Campina Grande/ PB, que lecionam no campo pesquisado, usam ou já usaram as tecnologias em sua prática educativa, a saber: quatro professores da Educação Infantil, cinco do Ensino Fundamental e oito do Ensino Médio.

Em relação à categorização dos sujeitos, todas as falas foram representadas pelas siglas (P.E.I), (P.E.F), (P.E.F.F) e (P.E.M) e separadas em grupos de acordo com seu nível de ensino, da seguinte forma: primeiro grupo (P.E.I): dos professores da Educação Infantil; segundo grupo (P.E.F): dos professores do Ensino Fundamental - séries iniciais; terceiro grupo (P.E.F.F): dos professores do Ensino Fundamental - séries finais; e o quarto grupo (P.E.M): dos professores do Ensino Médio. Ao lado de todos eles, foram colocados números de 01 a 10, que representam os professores individualmente. Essa classificação teve o objetivo de facilitar a compreensão em relação à totalidade do pensamento dos professores. Por questões éticas e para manter o anonimato dos sujeitos, também não foi feita distinção de gênero.

\section{TECNOLOGIA E EDUCAÇÃO: CONTEXTUALIZANDO O TEMPO PRESENTE}

Vivemos num mundo globalizado de incessantes transformações tecnológicas, paradoxalmente, um mundo incerto, cheio de opressão e desigualdade social.

Sabemos que estamos todos dentro de uma mesma nave, vivendo, construindo e reconstruindo um mundo cada vez mais complexo e plural, em função dos processos de interdependência que nos 
une. Um mundo complexo e também complicado, no qual prevalecem o imprevisível, o acaso, o inesperado sujeito à bifurcação e às emergências, tanto no plano individual como coletivo, no local como no global e planetário (MORAES, 2010, p.23).

Para o meio educacional, não é diferente, muitos desafios estão postos em meio a inúmeras incertezas. Segundo Baumam(2011), "Һ educação assumiu muitas formas no passado e se demonstrou capaz de adaptar-se à mudança das circunstâncias, de definir novos objetivos e laborar novas estratégias”. Portanto, parafraseando Morin (2003), é preciso repensar o contexto educacional, é preciso tecer ideias inovadoras para que surja um novo paradigma educacional. Pois, o desafio que está posto na sociedade contemporânea é a formação de sujeitos plurais. Desta forma, Moraes destaca:

Precisamos buscar novos referenciais teóricos e novas metáforas mais condizentes com a evolução da ciência e com as necessidades de nossa realidade atual. Buscar novas teorias que nos ajudem a ir mais além dos limites impostos pelo pensamento reducionista e simplificador do paradigma tradicional (MORAES, 2010, p.28).

Bauman (2001, p.125) afirma que precisamos conhecer/ aprender a arte de viver e de formar pessoas para vida. Nesse sentido, diante da crise paradigmática em que a educação encontra-se é preciso, cada vez mais, refletir sobre os processos educativos de maneira qualitativa focando as questões éticas e solidárias para formação de sujeitos completos capazes de atuarem na sociedade contemporânea.

Sobre esta questão, um ponto constante está presente nas discussões de Moraes (2010): O que é educar? A esta pergunta ela mesma responde que é necessário na concepção de educação ter um olhar para o futuro: 
Sob um olhar autopoético, educar é um fenômeno biológico fundamental que envolve todas as dimensões do viver humano, em total integração do corpo com a mente e o com o espírito, lembrando que, quando isso não ocorre, produzem-se alienação e a perda do sentido social e individual no viver/conviver. Educar é enriquecer a capacidade de ação e de reflexão do ser aprendente; é desenvolverse em parceria com outros seres (MORAES, 2010, p.41).

Assim, teremos uma visão de futuro transformadora, focando, sobretudo, na qualidade e não na quantidade dos processos educativos. Pois, somos responsáveis pelo paradigma educacional que instalamos, e este precisa ser um paradigma prudente, que também é um paradigma social, decente e necessário à vida, ou seja, trabalhar com conhecimentos que não sejam indiferentes à vida, pois nossas salas de aula presenciais ou a distância são um espaço dinâmico e precisa ser um espaço de múltiplos saberes.

\section{INFORMÁTICA EDUCACIONAL: REVISITANDO HISTÓRIA}

Os primeiros computadores (calculadoras programáveis capazes de armazenar os programas) surgiram na Inglaterra e nos Estados Unidos em 1945. No Brasil, o movimento da informática aplicada à educação tem sua origem na década de 1970, no setor administrativo das escolas, visando informatizar as secretarias das Escolas. A partir de 1980, surgem o EDUCOM (Educação e Computadores), o FORMAR (Professores Multiplicadores) e o PROINFE (Programa Nacional de Informática Educativa). Em 1997, é criado o PROINFO (Programa Nacional de Informática na Educação). Em 1995, discipli- 
nas de Informática na Educação começam a fazer parte dos currículos dos Cursos de Pedagogia e de Licenciatura.

Para Valente (1998, p.02), o termo 'Informática na educação refere-se à inserção do computador no processo de aprendizagem dos conteúdos curriculares de todos os níveis e modalidades de educação". Como se vê, o computador é um recurso que pode indicar múltiplos caminhos no processo de ensino-aprendizagem. Mas, para que isso aconteça, o professor deve assumir o papel de mediador dos conhecimentos e utilizar esses recursos de forma potencial em sua prática. O computador já faz parte do cotidiano escolar e, atualmente, representa para o trabalho docente um recurso indispensável, já que oferece um fazer educativo problematizador, ativo e protagonizante.

Apesar das inúmeras iniciativas governamentais, a introdução da Informática Educacional nas escolas públicas aconteceu de forma lenta e com certa indefinição do seu real objetivo. Em algumas escolas, os dirigentes e os professores interessavam-se em incrementar os currículos com o ensino básico dos conceitos da informática; outros buscavam utilizá-los como recurso no processo de ensino-aprendizagem e, nesse conflito, até hoje, os professores não assumiram, de fato e de maneira adequada, o uso da Informática em seu fazer pedagógico.

Nas instituições privadas, o processo de implantação aconteceu de maneira mais acelerada. Muitas delas aderiram a uma empresa especializada para auxiliar na montagem do Laboratório de Informática, contudo, quanto ao objetivo, isso não foi diferente da escola pública, e algumas escolas utilizavam para serem ministrados cursos de computação, cujo professor ensinava noções básicas de Informática (editores de textos, editores de gráficos, planilhas, banco de dados etc...), visando formar uma mão de obra qualificada para o mercado de trabalho; em outras, conforme avançavam os estudos e as 
pesquisas nessa área, os professores começaram a aliar os recursos tecnológicos oferecidos pelo computador aos conteúdos. De certa forma, muitas escolas privadas encontraram na Informática Educacional um recurso para o marketing.

Percebemos, todavia, que a introdução das tecnologias no contexto escolar é algo irreversível. Surgem novos paradigmas, práticas inovadoras do ensino, algumas geradas por força de obrigações externas dos modelos escolares, e outras, pelas mudanças de postura interna do docente, que passa a utilizar os computadores como um desafio em sua prática. De toda forma, o processo de mudança de paradigma educacional não acontece em igualdade com os avanços tecnológicos, conforme revela Valente (1999), se comparada com as mudanças em outros segmentos da sociedade que são incomparavelmente rápidas e que afetam diretamente o comportamento humano.

Hoje, as tecnologias, no contexto escolar, estão cada vez mais presentes: livros e cadernos são acompanhados por tablets nas mochilas escolares, a sala de aula do quadro negro é coisa do passado e o quadro branco convive com telas digitais, as aulas podem ser assistidas a distância e as tarefas de casa podem ser realizadas em redes sociais. As tecnologias têm provocado mudanças no contexto escolar, fazem emergir novos paradigmas ou perspectivas educativas. Assim, Coscarelli enfatiza:

Torna-se também imperativo fazer uso do potencial educativo das tecnologias da informação e da comunicação, pois acreditamos que, sem o suporte tecnológico, ficam comprometidas as chances de aumentar a variedade e a diversidade necessárias à sala de aula (COSCARELLI, 2006, p.27). 
Com o advento da internet como hipermídia e, sobretudo, a convergência das mídias, pode-se afirmar que o saber pode ser acessado e compartilhado em qualquer local e não mais restrito à sala de aula. Portanto, o cenário que se desenha para a educação é de preparar os alunos para saberem pensar criticamente. As diferentes possibilidades de uso que o computador traz para a prática pedagógica fazem professores e alunos estar antenados com um novo tempo, com novas formas de pensar e de agir e por que não dizer, na formação do 'homem novo", inserido em uma sociedade de constantes mudanças.

Portanto, compreendemos que é preciso estimular gestores e professores para o uso das tecnologias digitais, pois estamos imersos em uma variedade de opções para pesquisa e em diferentes maneiras de aprender e ensinar em um novo espaço em que alunos e professores podem elaborar seus conhecimentos de forma crítica, ativa e participativa.

\section{TECNOLOGIA NA EDUCAÇÃO, FORMAÇÃO E SABERES DOCENTES}

Refletir sobre a formação tecnológica do professor na perspectiva do uso das tecnologias digitais ganha destaque, quando se considera o papel da escola numa sociedade permeada por recursos tecnológicos, seja por iniciativas governamentais ou pela iniciativa dos estudantes. Valente (2011) coloca que é necessário repensar o papel da escola, neste mundo digital, o qual vem atribuindo aos educadores múltiplos dilemas de natureza epistemológica e teórico-metodológica, considerando-se a prática desses profissionais. Nesta mesma reflexão, Silva expressa: 
O professor precisa tomar consciência do movimento próprio das tecnologias digitais em sintonia com a sociedade da informação, com a cibercultura e com o perfil comunicacional dos aprendizes. Estes são cada vez menos subservientes à lógica unívoca das mídias de massa, quanto mais operam com o mouse, a tela tátil, as janelas móveis e tridimensionais que permitem mais que meramente olhar e assistir (SILVA, 2012, p.254).

Nessa perspectiva, é necessário que os professores enfrentem o desafio de buscarem novos conhecimentos e desenvolverem uma prática educativa aberta para a mudança, de forma, a enfrentar as inovações impostas pela sociedade da informação. Sendo assim, o professor precisa se apropriar dos conhecimentos necessários para o uso das tecnologias digitais em sala de aula.

Segundo Tardif (20011, p.39), o professor é "alguém que deve conhecer sua matéria, sua disciplina e seu programa, além de possuir certos conhecimentos relativos às ciências da educação e à pedagogia e desenvolver um saber prático baseado em sua experiência cotidiana com os alunos". Neste sentido, Tardif atesta que os saberes são plurais, formados pelos saberes da formação profissional, saberes disciplinares, saberes curriculares e saberes experienciais.

Desse modo, concordamos com Valente (2005) quando trata da experiência pedagógica do educador com o uso das tecnologias em sala de aula. Destacamos que os alunos têm mais habilidade para lidar com os artefatos tecnológicos, mas é preciso considerar que o professor é o ator competente para conduzir o processo educativo e a mediação da aprendizagem.

Desse modo, podemos inferir que o mundo moderno impõe novos formatos profissionais, um novo perfil de educador e exige novos saberes para lidar com a dinâmica do cenário educacional contemporâneo. É preciso que os professores se mostrem atentos às 
mudanças da sociedade, pois ação educativa requer sensibilidade, por exigir o compromisso contínuo do diálogo, da partilha e da negociação, com uma visão transdisciplinar e com capacidade constante de compreensão.

Dessa forma, as tecnologias digitais (Internet, software, jogos eletrônicos, entre outros) podem ser aliadas à prática docente, pois oferecem ao professor inúmeros caminhos para um fazer educativo inovador. A internet trouxe para a prática pedagógica novas formas de ensino - a colaboração, a comunicação e a imersão são termos novos que já fazem parte do contexto de ensino e geram o que Pierry Levy (1996) chamou de inteligência coletiva. Moran aborda muito bem essa questão ao afirmar que,

\begin{abstract}
Do ponto de vista metodológico, o educador precisa aprender a equilibrar processos de organização e de "provocação"na sala de aula. Uma das dimensões fundamentais do ato de educar é ajudar a encontrar uma lógica dentro do caos de informações que temos, organizá-las numa síntese coerente, mesmo que momentânea, compreendê-las. Compreender é organizar, sistematizar, comparar, avaliar, contextualizar. Uma segunda dimensão pedagógica procura questionar essa compreensão, criar uma tensão para superá-la, para modificá-la, para avançar para novas sínteses, outros momentos e formas de compreensão. Para isso, o professor precisa questionar, criar tensões produtivas e provocar o nível da compreensão existente (MORAN, 2009, p.101-111).
\end{abstract}

Moran explica que a

Educação é um caleidoscópio, pois, na forma como a enxergamos, teremos diferentes contextos educacionais e diferentes práticas educativas, e cada um terá sua lógica, seu fundamento, sua defesa, porque projetamos na educação nosso olhar parcial, nossas escolhas e nossas experiências (MORAN, 2007, p.13). 
Nesse sentido, Tardif (2011) conceitua que a educação é uma arte, uma técnica, uma interação e muitas outras coisas, mas também é a atividade por meio da qual prometemos às crianças e aos jovens um mundo sensato, onde devem ocupar um espaço que seja significativo para si mesmos.

As tecnologias digitais devem ser utilizadas na prática pedagógica como arte, como técnica e como interação, pois são recursos que podem auxiliar o processo de ensino-aprendizagem e a formação humana, um ensino colaborativo.

Diante deste contexto, é possível inferir que a inovação no contexto escolar começa com a ação e os professores precisam tecer saberes, produzir conhecimentos na prática pedagógica e propor atividades com o viés da inclusão e de forma contextualizada, integralizadora, em um processo flexível e personalizado, pois o acesso às novas formas de linguagens digitais, de acordo com Moran (2011), é um direito de cidadania plena.

Para a pergunta: Em que nível de ensino e como os professores usam o laboratório de informática? Construímos os quadros que seguem. 


\section{ACHADOS DA PESQUISA: CONCEPÇÃO E PRÁTICA EDUCATIVAS}

Quadro 1 - Ferramenta/recursos de apoio ao ensino/aprendizagem

\begin{tabular}{|c|c|c|}
\hline $\begin{array}{c}\text { Níveis de } \\
\text { Ensino }\end{array}$ & $\begin{array}{c}\text { Modalidade de uso da } \\
\text { Informática Educacional }\end{array}$ & $\begin{array}{c}\text { Relação com os conteú- } \\
\text { dos curriculares }\end{array}$ \\
\hline $\begin{array}{c}\text { Educação } \\
\text { Infantil }\end{array}$ & $\begin{array}{c}\text { Programas aplicativos } \\
\text { (Paint) }\end{array}$ & $\begin{array}{c}\text { Produzir e editar desenhos } \\
\text { (interdisciplinar) }\end{array}$ \\
\hline Ensino Fun- \\
damental (1
\end{tabular}

FONTE - As autoras 
Quadro 2 - Interação com o conhecimento de uma área específica: propostas de atividades no laboratório de informática

\begin{tabular}{|c|c|c|}
\hline Níveis de Ensino & $\begin{array}{l}\text { Modalidade de uso da } \\
\text { Informática Educacional }\end{array}$ & $\begin{array}{l}\text { Relação com os } \\
\text { conteúdos cur- } \\
\text { riculares }\end{array}$ \\
\hline Educação Infantil & $\begin{array}{c}\text { Software educativo (Comer- } \\
\text { ciais e programados pela } \\
\text { equipe da escola) } \\
\text { Jogos pedagógicos multi- } \\
\text { mídia } \\
\text { (quebra-cabeça, memória, } \\
\text { jogo da velha, Tangra). } \\
\text { Sites Infantis educativos } \\
\text { Vídeos educativos - Escola } \\
\text { Games } \\
\text { Games on-line }\end{array}$ & Interdisciplinar \\
\hline $\begin{array}{l}\text { Ensino Funda- } \\
\text { mental (10 ao } 5^{\circ} \\
\text { ano) }\end{array}$ & $\begin{array}{c}\text { Software } \\
\text { (HQ turma da Mônica) } \\
\text { Criar e recriar } \\
\text { Jogos educativos (Soletran- } \\
\text { do, explorando o planisfério) } \\
\text { Sites educativos } \\
\text { Site Escola Games } \\
\text { Vídeos }\end{array}$ & Interdisciplinar \\
\hline $\begin{array}{l}\text { Ensino Funda- } \\
\text { mental (6 } 6^{\circ} \text { ao } 9^{\circ} \\
\text { ano) }\end{array}$ & $\begin{array}{c}\text { Sites para produção de Histó- } \\
\text { ria em Quadrinho } \\
\text { Redes Sociais }\end{array}$ & Interdisciplinar \\
\hline Ensino Médio & $\begin{array}{c}\text { Pesquisa orientada na Inter- } \\
\text { net } \\
\text { Software educativo } \\
\text { Redes sociais } \\
\text { Vídeos }\end{array}$ & $\begin{array}{l}\text { Interdisciplinar } \\
\text { Por área do } \\
\text { conhecimento }\end{array}$ \\
\hline
\end{tabular}

FONTE - As autoras 


\title{
OS PROFESSORES E O LABORATÓRIO DE INFORMÁTICA: O QUE PENSAM E O QUE FAZEM?
}

Para a transcrição das falas, separamos os professores por nível de ensino. Inicialmente, Educação Infantil; o item seguinte refere-se aos professores do Ensino Fundamental (séries iniciais); depois do Ensino Fundamental (séries finais) e, por último, os professores do Ensino Médio, conforme relatos a seguir:

\section{PROFESSORES DA EDUCAÇÃO INFANTIL - (P.E.I)}

Qual o significado que você atribui à informática educacional ao seu fazer pedagógico? Como tem utilizado?

\begin{abstract}
Uso a informática educacional, semanalmente, e acho de extrema importância na minha prática, pois além de proporcionar o contato das crianças com o computador, também trabalha diversos aspectos cognitivos e motores através dos jogos lúdicos [...], podemos trabalhar o desenho a sequência lógica de maneira diferente da sala de aula (P.E.I 3) (informação verbal).
\end{abstract}

A informática já faz parte do meu planejamento [...], pois é a continuidade da minha sala de aula [...], a aprendizagem acontece através da ludicidade de forma muito forte [...], as crianças se sentem felizes no laboratório [...], percebo que consigo atingir meu objetivo, pois através dos softwares educativas são sugeridas atividades que contemplam os temas abordados em sala de aula (P.E.I 3) (informação verbal).

Nesse grupo de professores, ficou evidente o uso de sites educativos, softwares on-line e off-line, games, vídeos educativos no contexto da Informática Educacional. Os professores e alunos uti- 
lizam os contextos digitais no processo de interação com o conhecimento. De acordo com Moita (2007), é preciso que os professores promovam novas formas de interação e aprendizagem através de recursos on-line, levando em consideração o processo de aprendizagem sob perspectiva sociointeracionista. Pois, estes já fazem parte dos diferentes contextos do sujeito que se desenvolve e aprende imerso nas tecnologias.

O professor, como agente mediador dos conhecimentos, precisa saber utilizar o software e explorar ao máximo as possibilidades de uso. Ao redor do mundo inteiro, as crianças entraram em um mundo mágico de aprendizagem e de alegria com os computadores. Elas utilizam os computadores para escrever, para desenhar, para se comunicar e para obter informações. Elas são a geração da informática (PAPERT, 1994). O grande interesse das crianças pelo computador colabora para que aprendam facilmente a usá-lo, e o professor atento a isso, busca ampliar as possibilidades de aprendizagem através da Informática Educativa.

\section{PROFESSORES DO ENSINO FUNDAMENTAL (SÉRIES INICIAIS) SEGUNDO GRUPO (P.E.F)}

A informática educacional na minha prática é de suma importância, pois torna o conhecimento mais rico, criativo e interativo. Já faz parte do meu planejamento semanal. O professor precisa utilizar os avanços tecnológicos visto que o aluno já tem esse conhecimento. São recursos da modernidade [...] as aulas com recursos gráficos e de animação tornam-se mais interessantes e emocionantes, por exemplo: hoje nos emocionamos com um vídeo que utilizei no laboratório de informática (P.E.F 1) (informação verbal).

Gosto da informática, e sei o quanto ela é impor- 
tante no processo ensino-aprendizagem [...] na minha disciplina, os alunos aprendem melhor [...] observam e fazem uma relação bem maior do que quando a disciplina está lá sozinha, isolada, pois a aula se torna mais dinâmica, e a aprendizagem se torna produtiva. E eu consigo produzir muito mais no laboratório de informática! (P.E.F 4) (informação verbal).

Observando os professores desse grupo, constatamos que a Informática Educacional é usada sob dois enfoques: tanto para promover a interação com o conhecimento de uma área específica, através de software educativo, internet, de jogos educacionais on-line e off-line, programas tutoriais entre outros, quanto como recurso de apoio ao ensino-aprendizagem. Os contextos digitais trouxeram muitas novidades na maneira como ensinar e aprender.

A rede hipertextual está continuamente em construção e em negociação. Pode manter-se estável durante um determinado período, mas essa estabilidade é ela própria fruto de um trabalho. A sua extensão é um desafio permanente para atores envolvidos, quer estes sejam seres humanos, palavras, imagens. Traços, de imagens ou de contexto, objetos técnicos, componentes desses objetos etc (LÉVY, 1993, p.25).

Nessa perspectiva, os alunos constroem conhecimentos mediados pelos recursos disponíveis na rede, deixam de ser meros consumidores e passam a dar novos significados a sua identidade e aos novos saberes.

\section{PROFESSORES DO ENSINO FUNDAMENTAL - (SÉRIES FINAIS) TERCEIRO GRUPO (P.E.F.F)}

Acredito que a informática educacional propicia uma prática inovadora [...] Gosto de trabalhar com ferramentas web, acredito que faz o aluno criar, 
manipular, etc [...] mas temos muitas turmas, o tempo é curto por isso planejo atividades semestrais para o laboratório de informática [...], também tenho projeto que utilizo junto aos alunos a distância através de blogs. Os recursos da Web têm múltiplas possibilidades de uso, basta querer fazer. Com a internet fica fácil acompanhar as atividades produzidas em casa! (P.E.F.F 5) (informação verbal).

A informática educacional é uma ferramenta a mais na prática do professor [...], mas acho que os alunos ainda não estão preparados para usufruir dessas ferramentas. Quando chega no laboratório, os alunos ficam com essa coisa de jogos, de bate papa isso nos deixa muito stressada, pois o professor tem um objetivo e os alunos querem outro isso muitas vezes me desestimula de usar esses recursos (P.E.F.F 6) (informação verbal).

Nesse grupo de professores, encontramos percepções divergentes, apesar de serem do mesmo nível de ensino. Dos oito entrevistados, quatro se posicionaram resistentes ao uso da Informática Educacional. Eles relataram apenas as dificuldades de uso - falta de tempo, indisciplina dos alunos no laboratório e limitação teórico-prática. Já os demais, apesar de usarem a informática educacional da escola com pouca frequência, têm uma compreensão mais elaborada quanto ao seu uso, pois, além das pesquisas orientadas no laboratório de informática, utilizam a tecnologia para produzir e divulgar conhecimentos mediados por projetos. Essa produção acontece no laboratório de informática e continua com atividades em casa.

Essa deveria ser a prática mais usual da Informática Educacional, no entanto, ainda é a mais rara na escola pesquisada. Assim, mesmo diante da complexidade do contexto educacional é preciso que o professor tenha um olhar sensível, na busca de novas metodologias. Logo compreendemos que é preciso que tenhamos uma visão de futuro transformadora, com novos horizontes/paradigmas. 
As instrumentações eletrônicas, se adequadamente utilizadas em educação, poderão se constituir em ferramentas importantes capazes de colaborar para a melhoria da qualidade do processo de aprendizagem, estimulando a criação de novos ambientes educacionais e de novas dinâmicas sociais de aprendizagem, colaborando, assim, para o surgimento de certos tipos de reflexões mentais que favorecem a imaginação, a intuição, a capacidade decisória, a criatividade, aspectos estes fundamentais para a sobrevivência individual e coletiva (MORAES,2010, p.09).

Podemos afirmar que o professor (P.E.F 5)realiza uma prática significativa e responsável, voltada para um ensino de qualidade na aprendizagem dos alunos, visto que emprega os recursos tecnológicos em sua prática com competência. Acreditamos que esse professor criou uma metodologia de ensino que auxilia o aluno como criação, interpretação e comunicação e tem a Informática Educacional como uma grande aliada em sua prática de ensino. Conforme define Moran (2007, p.101), do ponto de vista metodológico,

o educador precisa aprender a equilibrar processos de organização e de "provocação" na sala de aula. Uma das dimensões fundamentais do ato de educar é ajudar a encontrar uma lógica dentro do caos de informações que temos, organizá-las numa síntese coerente, mesmo que momentânea, compreendê-las.

\section{PROFESSORES DO ENSINO MÉDIO QUARTO GRUPO (PEM)}

'O tempo para desenvolver projetos na informática é pouco, pois a carga horária é muito apertada" (P.E.M 8) (informação verbal). 
A tecnologia na educação é algo positiva pela diversidade de ferramenta e informação que ela possui, se usando corretamente há possibilidades de aulas maravilhosas, no Ensino Médio o tempo é muito curso, em especial agora, que o ENEM é em outubro e precisamos correr com os conteúdos (P.E.M 4) (informação verbal).

É um recurso muito importante, [...] é uma forma que os alunos têm de associar os conteúdos de sala de aula através de recursos que tem fora dela. Costumo passar atividades para casa com o uso desses recursos, pois até por que o aluno tem mais tempo de pesquisar na internet, de usar jogos [...] tudo isso vai ajudar no crescimento do conhecimento do aluno. Na escola, raramente uso o laboratório de informática, pois além do tempo que é curto os alunos ficam muito ansiosos, gosto de usar a sala multimídia, mas é sempre lotada, por exemplo: esse mês já tentei marcar três vezes e não consigo vaga, ou seja, são poucos os espaços informatizados para muitos professores (P.E.M 1) (informação verbal).

A informática na educação é muito importante na prática educativa, pois ajuda ao aluno a compreender melhor os conhecimentos adquiridos através da ferramenta utilizada, os alunos apreendem melhor [...], pois a aprendizagem hoje ela é muito mais, quando você ouve, pratica e ver e a tecnologia educacional, ela proporciona que o aluno ouça, veja e coloque a mão na massa (P.E.M 5) (informação verbal).

No quarto e último grupo, foi possível perceber um bom nível de sensibilização/conscientização de professores em relação à necessidade/importância da inserção dos recursos tecnológicos em suas práticas pedagógicas, o que indica menos resistência quanto ao uso dos contextos digitais na ação pedagógica. Os professores desse grupo apresentaram um bom nível de conhecimento teórico-prático e mencionaram discursos de práticas inovadoras. Contudo, a maioria 
prefere usar as redes sociais, email e vídeos em sala de aula e faz pouco uso do Laboratório de Informática da escola.

Quando perguntado o motivo de não usar as tecnologias, os professores mencionaram diferentes justificativas: Carga horária da disciplina pequena para ministrar todo o conteúdo previsto, inviabilizando a saída de sala para utilização do Laboratório de Informática devido à perda de tempo com deslocamento e reorganização da turma nestes espaços; Indisponibilidade de horários para planejamento/elaboração junto à equipe de informática de aulas utilizando esses recursos; Conteúdo da disciplina inadequado para o uso dos recursos informáticos; Desconhecimento dos recursos tecnológicos (medo de errar) e Inadequação dos espaços físicos.

Isso colabora com as pesquisas realizadas por Moran (2007), quando destaca a internet e outros recursos que vêm modificando a vida no dia a dia. A sociedade vive conectada e, como reflexo, mudou as formas de viver, sentir e pensar. No entanto, a educação ainda permanece arraigada a velhas práticas educativas.

\section{CONSIDERAÇÕES FINAIS}

À medida que se reconhece a escola como um espaço difusor do saber e de formação de cidadãos críticos, é fundamental refletir sobre os processos educativos em seu interior. Nesse sentido, a prática pedagógica do professor com o uso da Informática Educacional foi foco deste estudo, visto que avaliar e redimensionar é sempre necessário. Acreditamos que esta pesquisa, mesmo que parcialmente, sinalizou aspectos relevantes sobre a utilização da Informática Educacional pelos professores no cotidiano escolar. Pelo que foi visto, em uma perspectiva geral da pesquisa, ainda existem alguns desafios que 
podem ser enfrentados diante das práticas observadas, entre os quais, destacamos: a integração teoria-prática; um planejamento mais sistematizado e contínuo; a atuação do professor como agente mediador no espaço do laboratório e o uso do computador para além da pesquisa e do software.

Assim, considerando esses aspectos, entendemos que a escola deve ter um projeto permanente/contínuo de formação docente na área de Educação e Tecnologia, o que agregaria melhores condições de trabalho para os docentes. Isso se justifica porque, diante da velocidade da informação, da grande mutação tecnológica e da convergência das mídias, a escola não pode ficar ausente desse contexto. Sugerimos, ainda, que o projeto de Informática Educacional seja revisitado, pois a pesquisa evidenciou diferentes ações, percepções e práticas dos professores quanto ao uso dessa ferramenta no mesmo espaço educativo.

O estudo também revelou o importante significado da Informática Educacional no contexto escolar, porquanto o professor tem múltiplos suportes de informação e de comunicação, várias formas de problematizar e organizar o tema proposto junto com os alunos e, como resultado, uma aprendizagem significativa e a formação de sujeitos para uma sociedade de constante mudanças. Ressaltamos a relevância da pesquisa realizada, ao associar à prática pedagógica do professor o uso da Informática Educacional no cotidiano escolar, e os contextos digitais utilizados, como consequência, configuram-se novas formas de ensinar e de aprender.

Nessa perspectiva, entendemos que qualquer que seja a modalidade de uso do computador, ou qualquer outro recurso tecnológico, é necessária uma postura ativa do professor para que as Tecnologias da Informação e Comunicação (TIC) gerem os saberes que são exigidos pela educação contemporânea (VALENTE, 2003). 


\section{REFERÊNCIAS}

BAUMAN, Z $\mathbf{4 4}$ cartas do mundo líquido moderno. Tradução: Vera Pereira. Rio de Janeiro: Jorge Zahar, 2011.

CHIZOTTI, A. Pesquisa em ciências humanas e sociais. 5. ed. São Paulo, Cortez, 2001, 164p. (Biblioteca de Educação. Série 1 - Escola - v.16).

COSCARELLI, C. V. (Org.) Novas tecnologias, novos textos, novas formas de pensar. Belo Horizonte: Autêntica, 2002.

FREIRE, P. Pedagogia da autonomia: saberes necessários à prática educativa. 36. ed. São Paulo: Paz e Terra, 1996.

LÉVY, P. Cibercutura. 2.ed. São Paulo: Editora 34, 2000.

O que é o virtual? São Paulo: Ed. 34, 1996.

As tecnologias da inteligência. $O$ futuro do pensamento na Era da Informática. São Paulo: Editora 34, 1993.

MORAES, M. C. Ambientes de aprendizagem como expressão de convivência e transformação. In: MORAES, M. C.; BATALLOSO NAVAS, J. M. (Orgs). Complexidade e transdisciplinaridade em educação: teoria e prática docente. Rio de Janeiro: Wak Editora, 2010. 
MORAES, M.C.B. O paradigma educacional emergente- implicações na prática do professor e nas práticas pedagógicas. Em Aberto, Brasília, 16, n.70, abr/jun. 1996.

MARCONI, M.; LAKATOS, E. Técnicas de pesquisa: planejamento e execução de pesquisas, amostragens e técnicas de pesquisas, elaboração, análise e interpretação de dados. 3. ed. São Paulo: Atlas, 1996, 231p.

MOITA, F.M.G.S.C. Game on: os jogos electrônicos na escola e na vida da geração@.São Paulo: Atomoealinea, 2007.

MORAN, J. M. A educação que desejamos: novos desafios e como chegar lá. Campinas: Editora Papirus. - SP, 2007.

MORAN, J. M. Ensino e aprendizagem inovadores com tecnologia. In http: www.eca.usp.br/moran/inov.html».Acesso out. 2012.

MORIN, E. A cabeça bem-feita: repensar a reforma, repensar o pensamento. Rio de Janeiro: Bertrand Brasil, 2001.

NETO, O. C. “O trabalho de campo como descoberta e criação”. In: MINAYO, M. (org.). Pesquisa social: teoria, método e criatividade. 10. ed. Petrópolis: Rio de Janeiro: vozes, 1998, 79 p. (Coleção Temas Sociais).

SILVA, M. Sala de aula interativa: educação, comunicação, mídia clássica... 6.ed. São Paulo: Edições Loyola, 2012. 
TARDIF, M. Saberes docentes e formação profissional. 12.ed. Rio de Janeiro: Vozes, 2011.

VALENTE, J. A. Computadores e conhecimento: repensando a educação. Campinas: UNICAMP, 1993.

VALENTE, J.A. As tecnologias digitais e os diferentes letramentos. Pátio-Revista Pedagógica, ano XI, n.44, p.12-15, Porto Alegre, 2007. Informática na educação no Brasil: análise e contextualização histórica. In: VALENTE, José Armando (org.). 0 computador na sociedade do conhecimento. Campinas: UNICAMP / NIED, 1999, p. 01-27. 


\author{
Rodrigo Lins Rodrigues \\ Filomena M. G. da Silva C. Moita
}

\title{
INTRODUÇÃO
}

Nos últimos anos, uma proliferação de novos sistemas vem surgindo para melhorar/facilitar o ensino e a assimilação das informações (LAUDONK; LAUDON, 2007). Pesquisas recentes, como as de Bastos (2007) e Schoenfelder (2008), mostram que muitos desses ambientes educacionais têm sido desenvolvidos com as mais novas tecnologias do mercado. Uma dessas tecnologias emergentes que está sendo muito utilizada para o ensino chama-se Realidade Aumentada (RA), que é a sobreposição de objetos virtuais tridimensionais, gerados por computador, em um ambiente real, por meio de algum dispositivo tecnológico. A RA enriquece o ambiente físico com objetos virtuais e amplia o entendimento do ambiente real. Esses sistemas podem ser usados tanto em plataformas sofisticadas quanto em plataformas populares e estão sendo aplicados em várias áreas, como: ensino, marketing, indústria, saúde etc. (GABBARDJ. L.; SWA N, 2008). 
Apesar do aumento na utilização de ambientes de RA, eles apresentam, principalmente, no ensino e na aprendizagem, um grande desafio: o de projetar interfaces para o usuário, pois projetistas de RA não têm estabelecido um conjunto de diretrizes ou heurísticas para ajudar na implementação (JEONS, SHIM, 2006; KULAS, KLINKER, 2004; FERNANDES, SANCHES, 2008; VANDERDONCKT, CHIEU, 2004; BOANANNI, LEE, 2005). Segundo Wang e Reeves (2007), a usabilidade não tem recebido um foco adequado, visto que não se volta para os diferentes usuários e suas diferentes capacidades na utilização das tecnologias. Muitos designers instrucionais criam objetos de aprendizagem sem investigar se esse recurso é adequado para o público que vai utilizá-lo. Eles também não se preocupam em realizar uma pesquisa, uma análise de requisitos antes da construção do software e, não raras vezes, deixam a avaliação para o final do desenvolvimento do software, o que é muito mais complicado e oneroso. Costabili e Marisco (2005) afirmam que aplicações para o ensino, como objetos de aprendizagem, devem ser usadas com facilidade. Caso contrário, o tempo do estudante será desperdiçado com a aplicação, ao invés de ser aproveitado para aprender. Costabili e Marisco (2005) complementam que pessoas se recusam a usar uma interface de um sistema que seja rígida, lenta e desagradável e acabam interrompendo o curso. Essa facilidade de uso está relacionada à usabilidade, que deve ser trabalhada desde a criação do projeto, mas os desenvolvedores, comumente, não dispõem de recursos suficientes, tempo ou conhecimentos adequados para identificar as necessidades de usabilidade de todos os usuários potenciais. Porém, essa consciência é parte importante do processo de desenvolvimento do software (Engenharia de Usabilidade) e exige mais estudo e atenção daqueles que desenvolvem os ambientes de aprendizagem. 
Quando examinadas várias abordagens de engenharia de usabilidade tradicionais, especificadamente, projetos e atividades de avaliação, na maioria dos casos, atividades de projeto são alavancadas por metáforas existentes, guias ou padrões. Contudo, em casos em que a tecnologia provê abordagens modernas para a interação dos usuários ou fundamentalmente altera o seu modo de perceber o espaço de interação, como acontece com RA, projetistas, frequentemente, pouco compreendem as ramificações perceptivas ou cognitivas do projeto e não sabem como cada usuário irá se adaptar às condições do ambiente do sistema (como manipulação de ambientes reais e virtuais ao mesmo tempo, uso de capacetes, uso de câmeras de vídeo, marcadores etc.).

Como resultado, processos/metodologias são necessários para ajudar os projetistas de novas tecnologias, como a RA, a criarem e a avaliarem os projetos, os quais passam a entender bem mais os efetivos parâmetros e determinam em que condições esses parâmetros devem ser aplicados. Sem esses processos, aplicações desenvolvidas, usando-se a engenharia de usabilidade tradicional, podem ou não melhorar a usabilidade do sistema (AMADO, 2007).

Assim, devido a esse contexto, o objetivo deste trabalho foi o de criar um protótipo para a utilização RA, com vistas a visualizar e manipular objetos virtuais, com o intuito de facilitar as demonstrações geométricas em ambientes educacionais.

\section{JUSTIFICATIVA}

Os Sistemas de Geometria Dinâmica (SGD) facilitam a construção e a manipulação de objetos geométricos no computador. Segundo Aguiar (2009), nos SGD, as relações geométricas são exploradas de maneira interativa, e os teoremas são descobertos empirica- 
mente. Existem vários sistemas desse tipo, entre eles, podem-se citar Cabri-Géomètre, Geometer's Sketchpad e Tabulæ.

Há diversos trabalhos que estudam os impactos do uso de SGD no aprendizado. Gomes (2008, p.12) acredita que "os trabalhos conduzidos sobre a contribuição dos SGD à aprendizagem de Geometria mostram que eles facilitam a emergência de conceitos geométricos".

Para Costa et al. (2009), o estudo de Geometria é de suma importância para o desenvolvimento da capacidade de abstrair e resolver problemas práticos do quotidiano, estimar e comparar resultados e reconhecer propriedades das formas geométricas. Os autores acrescentam que, algumas vezes, a Geometria é trabalhada separadamente da Matemática, o que leva o aluno a não desenvolver habilidades como noção espacial, raciocínio dedutivo e representação geométrica.

Já para Lima et al. (2005), os objetos da Geometria podem ser representados de modo gráfico, material, porém seu trabalho matemático envolve a abstração do real e implica a utilização de um conjunto de relações lógico-matemáticas.

Observando a deficiência do ensino matemático brasileiro de tal abstração, o grupo se interessou pelo tópico em busca de uma nova abordagem que auxiliasse os professores. Além disso, conhecer Geometria permite que se elaborem modelos da realidade e que se resolvam diversos problemas práticos, como por exemplo, nas áreas de Arquitetura, Engenharia, Geografia, Artes Plásticas, planejamento urbano e regional, design de superfície etc.

Nesse contexto, a utilização da RA pode oferecer informações sensitivas mais ricas, que facilitam a associação e a reflexão sobre o tema que está sendo ensinado. $\mathrm{O}$ uso de RA pode fazer com que o usuário possa lidar, de forma mais confortável, com conceitos abstra- 
tos (AZUMA, 2001). Portanto, é razoável pensar em uma proposta que una os benefícios dos Sistemas de Geometria Dinâmica com a Realidade Aumentada.

\section{FUNDAMENTAÇÃO TEÓRICA}

Nesta seção, apresentamos a fundamentação teórica necessária para o desenvolvimento desta pesquisa e os conceitos básicos para se entender a tecnologia da RA, especificadamente, com foco em educação. Para isso, abordamos os seguintes aspectos: um marco histórico sobre a evolução da Realidade Aumentada, suas características, principais aplicações e demais aspectos relativos a essa tecnologia.

\section{MARCO HISTÓRICO}

Ainda que a Realidade Aumentada seja pouco conhecida na educação e que as pesquisas nessa área estejam apenas se iniciando, sua concepção é mais antiga do que a princípio se poderia supor. O primeiro experimento de RA considerado como tal foi feito por Sutherland, ainda na década de 60, quando ele utilizou um capacete com visor transparente no qual foram apresentadas imagens 3D (AZUMA, 1997).

A área de pesquisa formou-se, no entanto, apenas na década de 90, quando a existência de um número maior de trabalhos possibilitou que ela fosse identificada e caracterizada como um tópico distinto de outros. As pesquisas aceleraram-se a partir de 1997, quando um survey de Azuma (1997) definiu esse campo de estudo, descreveu os principais problemas e relacionou os trabalhos realizados até então. No final da década de 90, surgiram os primeiros workshops e simpó- 
sios, bem como organizações voltadas especificamente para esse tema. Outro fator que acelerou o número de pesquisas na área foi a disponibilização do ARToolKit, uma biblioteca para desenvolvimento rápido de aplicações de RA. Inicialmente desenvolvido na Universidade do Japão, atualmente é apoiado pela Universidade de Washington, nos EUA, e pela Universidade de Canterbury, na Nova Zelândia.

A fim de compreender o que é Realidade Aumentada, é interessante situá-la no contexto da Realidade Virtual(RV), bem como verificar o que diferencia uma da outra. Credita-se a Jaron Lanier, fundador da VPL Research Inc, o termo Realidade Virtual (HEISS, 2003). $\mathrm{Na}$ década de 1980, ele o teria utilizado para diferenciar as simulações tradicionais dos mundos virtuais que ele tentava criar. A partir daí, muitas definições foram propostas.

Aukstakalnis (apud VALLINO, 1998) afirma que a Realidade Virtual é um ambiente tridimensional, interativo e gerado por computador, no qual uma pessoa é imersa. Para Neto (2004), o termo refere-se, normalmente, a uma experiência imersiva e interativa baseada em imagens gráficas 3D, geradas em tempo-real por computador. Além disso, vários pesquisadores explicitam que a Realidade Virtual é uma interface (NETTO; MACHADO, 2005; KIRNER, 2005).

Nas duas definições apresentadas, estão presentes elementos que, em conjunto, caracterizam essa área de pesquisa: o ambiente gerado por computador, a tridimensionalidade e a interatividade em tempo real. Filmes e animações não são dotados de interatividade, portanto, não são considerados Realidade Virtual. Outro aspecto a ser observado é quanto ao nível de imersão: embora a desconexão total do mundo real seja o ambiente que mais caracteriza a Realidade Virtual e esteja presente em algumas definições, a imersão total nem sempre 
é exigida. Nesses casos, jogos tridimensionais em computadores convencionais podem ser considerados como Realidade Virtual.

Devido às características de geração de imagens tridimensionais, de interatividade e de utilização de uma série de tecnologias, equipamentos e soluções comuns, a RA é entendida como uma subárea da Realidade Virtual. De acordo com Santos (2001), o termo refere-se à composição de ambientes reais com ambientes simulados. Para Insley (2003a), ela é a melhoria do mundo real com textos, imagens e objetos virtuais gerados por computador. Azuma (1997, pp.355-385) considera que a Realidade Aumentada "suplementa o mundo real com objetos virtuais que parecem coexistir no mesmo espaço do mundo real"e define um sistema de Realidade Aumentada como aquele que apresenta as seguintes características: "combina objetos reais e virtuais num ambiente real; opera interativamente e em tempo real e registra (alinha) objetos reais e virtuais uns com os outros."

Essa definição, ao contrário de outras, não restringe os sistemas de Realidade Aumentada a fazerem uso de determinada tecnologia de apresentação, como a dos capacetes Head-Worn Display (HWD). Também não se limita ao sentido da visão, já que, potencialmente, todos os demais sentidos podem ter seus equivalentes virtuais.

Outra observação sobre a definição de Azuma, é que, ele considera como parte da Realidade Aumentada o que outros pesquisadores denominam Realidade Mediada ou Realidade Diminuída, isto é, a "remoção"de objetos reais da cena. Por exemplo, a inclusão de um objeto virtual na frente de outro real tem o efeito de "subtraí-lo"e fazer com que ele não seja percebido.

Em 1994, Milgram e Kishino (1994, pp.1321-1329) propuseram uma taxonomia, ao observar que o termo Realidade Virtual vinha sendo aplicado a uma série de ambientes, nem sempre com 
imersão total. Ele identificou que esses ambientes se encontravam em algum ponto que ele denominou "Virtuality Continuum", ou um "Contínuo de Virtualidade", cujos extremos são o ambiente real e a Realidade Virtual. Entre um extremo e outro, está o que ele denominou de Realidade Misturada e definiu como sendo aquela em que "objetos do mundo real e do mundo virtual são apresentados juntos num único dispositivo de apresentação, ou seja, em qualquer local entre os extremos do continuum". Assim, a Realidade Aumentada caracterizase pelo predomínio do mundo real sobre o virtual, enquanto que, na Virtualidade Aumentada, predomina o virtual sobre o real.

\section{CARACTERÍSTICAS DA REALIDADE AUMENTADA}

Devido à abundância de termos e a interesses das áreas de Realidade Virtual e Aumentada, em função de sua multidisciplinaridade, serão abordados, em seguida, alguns conceitos relativos ao assunto.

\section{- Multimídia}

Multimídia é a integração, controlada por computador, de textos gráficos, imagens, vídeo, animações, áudio e outras mídias, que possam representar, armazenar, transmitir e processar informações de forma digital. As aplicações multimídia são potentes e simples de se usar, mas restringem a visualização do usuário à tela do computador (2D). Essa deficiência pode ser atenuada com o aproveitamento do espaço da tela do monitor, através de múltiplas janelas sobrepostas ou espalhadas. 


\section{- Rastreamento}

$\mathrm{O}$ rastreamento, em ambientes de Realidade Virtual e Aumentada, tem a função de identificar a posição da mão e da cabeça do próprio usuário ou de algo atrelado a ele, como uma placa. Com isso, o sistema permite que o usuário exerça um controle de posicionamento em ambientes virtuais ou aumentados e possa, por exemplo, movimentar-se e tocar, agarrar, mover e soltar objetos virtuais. Para uso em aplicações de Realidade Virtual, muitos dispositivos de rastreamento foram desenvolvidos usando-se princípios mecânicos, magnéticos, de ultrassom etc.

\section{- Realidade Aumentada e educação}

A educação pode ser vista como um processo de descoberta, de exploração e de observação, além de eterna construção do conhecimento. Por isso, as características específicas da RA podem transformá-la num poderoso instrumento a serviço de todos os que buscam a evolução da educação. A RA dará um grande salto em inúmeras áreas do conhecimento existentes, mas, principalmente, na educação, porque permite que sejam feitas experiências com o conhecimento de forma imersiva e interativa, ou seja, que ocorra aprendizagem sobre um determinado tema inserido no contexto e, a cada ação, haja um feedback.

\section{DESENVOLVIMENTO DO PROTÓTIPO}

No decorrer deste trabalho, considerado como um estudo de caso, foi desenvolvido um protótipo em que se utilizam técnicas de Realidade Aumentada, visando demonstrar o potencial da tecnologia no âmbito educacional. Para isso, foi prototipada uma aplicação uti- 
lizando-se rastreamento de mão sem marcadores, tendo em vista que essa é uma área de pesquisa muito recente.

\section{METODOLOGIA}

Inicialmente, procedemos à revisão de literatura, para saber quais são os trabalhos que vêm sendo realizados no campo da Realidade Aumentada e que facilitam o ensino e a visualização de figuras geométricas. Para isso, foram feitas entrevistas com professores de Matemática, com o objetivo de colher ideias sobre como a RA auxiliaria as aulas de Geometria e validar os requisitos elicitados durante a revisão da literatura. Também foi realizada uma análise de competidores para levantar requisitos.

Com o resultado da revisão da literatura em mãos e as ideias coletadas por meio das entrevistas, desenvolvemos um protótipo de baixa fidelidade para ser avaliado com os usuários. De acordo com a avaliação feita, o protótipo foi refinado e transformado em um protótipo funcional.

\section{ANÁLISE DE COMPETIDORES}

A análise de competidores foi uma das técnicas da engenharia da usabilidade que utilizamos durante os passos da metodologia, cuja meta foi estudar produtos concorrentes, utilizando-se critérios específicos de avaliação, de forma a conhecer seus pontos fortes e fracos. Entre as vantagens da análise de competidores, podemos citar: a avaliação de pontos fortes e fracos da concorrência; a obtenção de ideias para o design de software e a obtenção de requisitos. 
As análises realizadas nos softwares de Geometria foram feitas com base na instalação das ferramentas e no uso delas. Já as análises dos softwares de RA foram baseadas em vídeos e depoimentos sobre o uso dessas ferramentas. Foram analisados seis softwares: dois de Geometria 3D (Poly e K3Dsurf), dois de Realidade Aumentada com marcadores (ARToolkit e FLARToolkit) e dois de Realidade Aumentada sem marcadores (Motion Tracker e Ostrich Flash).

\section{ENTREVISTA}

A entrevista foi a forma inicial que empregamos para coletar os dados. Segundo (HAGUETTE; FHAGUETTE, 1997), a entrevista é um processo de interação social entre duas pessoas, em que uma delas, o entrevistador, tem o objetivo de colher informações por parte do outro, o entrevistado.

A utilização dessa técnica, na elicitação dos requisitos, teve como finalidade ouvir o professor de Geometria falando sobre as dificuldades de demonstrar figuras geométricas de forma dinâmica, visando obter uma explanação dos pontos e opiniões sobre esse assunto. Com a utilização dessa técnica, foi possível elicitar alguns requisitos para a construção do protótipo do software.

\section{DESENVOLVIMENTO}

A aplicação foi desenvolvida com base na prototipagem e na análise de requisitos feitos anteriormente. Para isso, empregamos técnicas de computação gráfica e processamento de imagem. Um dos critérios para a análise de requisitos foi que a aplicação pudesse ser 
visualizada via browser. Para isso, fizemos um levantamento de linguagens que dessem esse suporte ao domínio da aplicação.

\section{TÉCNICA DE RASTREAMENTO}

A técnica utilizada para rastrear os movimentos da mão consiste em salvar o quadro atual e os anteriores na memória e calcular as áreas na imagem onde o próximo ponto é diferente do anterior. A imagem resultante é turva e produz uma imagem como esta:

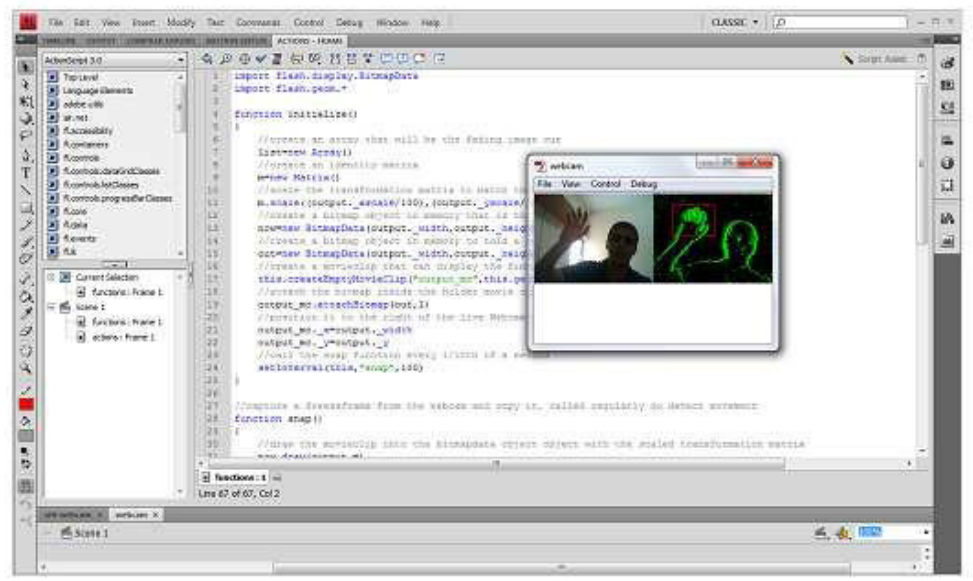

FIGURA 1 - Aplicação de filtro para detecção de pontos deslocados FONTE - Os autores

Então, a região de movimento pode ser identificada através do cálculo da menor caixa delimitadora que contém todos os pixels acima do limite, ou seja, todos os pixels em verde. Depois que a caixa é feita, é possível acompanhar o movimento em torno do campo da câmera de vista e, a partir daí, detectar a região onde ocorreu o movimento. 


\section{LINGUAGEM E BIBLIOTECAS UTILIZADAS}

Um dos requisitos encontrados para esse protótipo foi que ele deveria ser construído de forma a ser utilizado via browser. Assim, utilizamos a API (biblioteca) em Flash, chamada de Ostrich. Essa biblioteca nos permitiu implementar as características propostas para o protótipo.

A API Ostrich foi estudada e analisada como outras bibliotecas disponíveis para detectar movimentos, utilizando-se a linguagem ActionScript 3.0. A escolha de uma API para a tecnologia Flash foi feita por causa da simplicidade de ser aplicada pelo usuário final e pelo fato de a portabilidade de seu produto final ser executada para a Web e em desktop. O sistema com o auxílio da API Ostrich foi desenvolvido e uma primeira versão do protótipo para demonstração, cujo resultado foi satisfatório.

\section{PROTOTIPAGEM}

A partir dos requisitos obtidos com a revisão de literatura, com a análise de competidores e com a execução das entrevistas, desenvolvemos um protótipo de baixa fidelidade para visualizar bem o problema e sua possível solução. Depois de ser avaliado, o protótipo foi refinado, gerando uma segunda versão de forma funcional. 


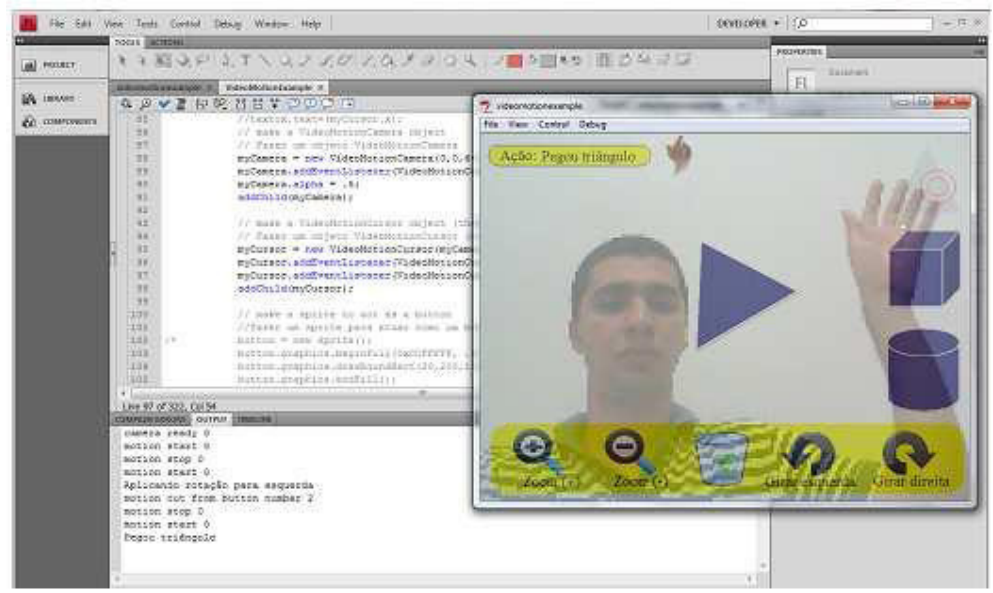

FIGURA 2 - Protótipo funcional FONTE - Os autores

Concluída a construção da aplicação, elaboramos um cenário onde seria aplicado o protótipo para ser avaliado. Ele foi constituído de uma sala com computadores ligados à webcam, onde foi instalado o protótipo desenvolvido.

\section{RESULTADOS E AVALIAÇÃO}

O protótipo desenvolvido foi aplicado com dez alunos do Mestrado em Ensino de Ciências e Educação Matemática da Universidade Estadual da Paraíba. Esse processo ocorreu em dois momentos: no primeiro, os professores receberam uma explanação sobre o conceito de Realidade Aumentada; em seguida, foram mostradas algumas aplicações já existentes no mercado, em relação à tecnologia utilizada; no segundo momento, os professores utilizaram o protótipo desenvolvido. 
Posteriormente, aplicamos um questionário, dividido em três categorias: questões referentes ao conhecimento sobre Realidade Aumentada, sobre a usabilidade da ferramenta e sobre o potencial pedagógico da ferramenta. Em relação a essas categorias, obtivemos os seguintes resultados: quanto ao sexo dos participantes, constatamos que 50\% de usuários são do sexo masculino, e 50\% , do feminino, dos quais, $60 \%$ afirmaram que já haviam ministrado disciplinas de Geometria.

A figura abaixo mostra o resultado da opinião dos professores, no que diz respeito ao conhecimento sobre a técnica de Realidade Aumentada.

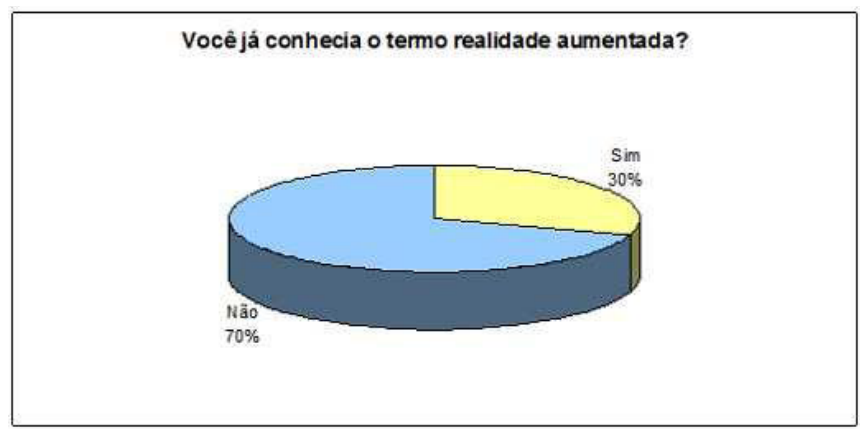

FIGURA 3 - Entrevistados que conheciam o termo "Realidade Aumentada" FONTE - Os autores

Observa-se que a maioria dos professores entrevistados (70\% ) não conhecia o termo Realidade Aumentada, até antes da entrevista.

A figura a seguir mostra alguns resultados referentes a uma escala de pontuação de zero a cinco, com as características do protótipo, tais como: funcionalidade, usabilidade, confiabilidade, eficiência, manutenibilidade e portabilidade. 


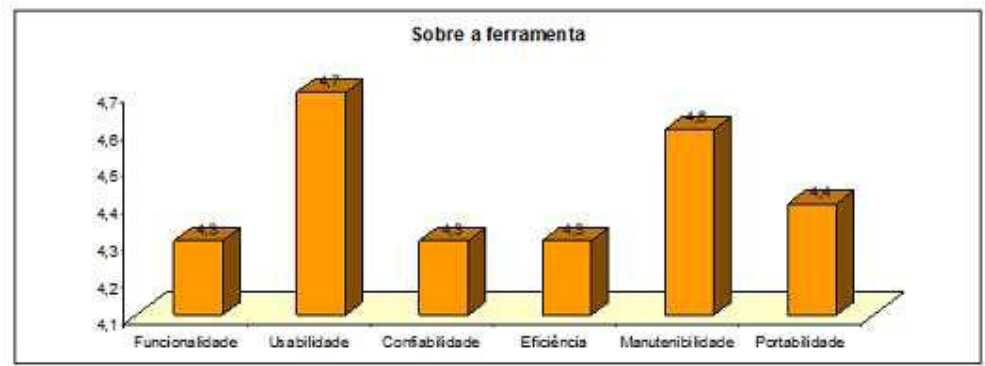

FIGURA 4 - Avaliação das características da ferramenta FONTE - Os autores

A característica que mais se destacou foi a usabilidade da ferramenta, que trata da facilidade de se utilizar o protótipo. Em seguida, a manutenibilidade, ou seja, na opinião dos professores, a ferramenta desenvolvida proporciona evidências de que há facilidade para correções, atualizações e alterações. Essa é uma das características do protótipo proposto - poder ser adaptado para diversos conteúdos.

A figura 5 mostra a opinião dos professores em relação à dificuldade de empregar o protótipo. Os resultados demonstraram que o protótipo desenvolvido neste projeto foi de fácil manuseio, para que os professores não tenham que dedicar muito tempo para aprender a utilizar esse ambiente.

\section{Qual o nivel de dificuldade que você achou sobre o uso da ferramenta?}

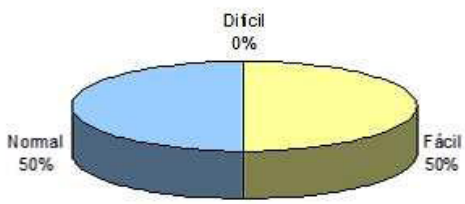

FIGURA 5 - Nível de dificuldade no uso da ferramenta pelos entrevistados FONTE - Os autores 
Diante do que foi visto, podemos inferir que a ferramenta foi muito bem aceita para ser utilizada no ensino de Geometria. Isso contribui para que o professor tenha mais facilidade de demonstrar as formas geométricas para os seus alunos.

\section{CONCLUSÃO}

Os estudos iniciais deste trabalho mostraram que se trata de uma inovação significativa, do ponto de vista acadêmico, visto seu potencial inovador e sua forma intuitiva de interagir com o usuário, porquanto apresenta uma solução de baixo custo. A avaliação de desempenho mostrou novas alternativas para otimizar o processo de visualização, bem como novos caminhos, no sentido de viabilizar o uso desse recurso em aplicações presentes no cotidiano, por meio de equipamentos comumente encontrados no mercado. Portanto, tratase de um trabalho inovador, na medida em que traz uma contribuição significativa para a utilização da Realidade Aumentada na visualização de objetos em 3D. Como trabalhos futuros, pretendemos aplicar a ferramenta em um ambiente educacional real, a fim de entender os reais benefícios cognitivos do seu uso. 


\section{REFERÊNCIAS}

AZUMA. R. T. A Survey of Augmented Reality. Presence: Teleoperators and Virtual Environments, n. 6, Ano 4, Agosto de 1997, pp. 355 - 385. Disponível em 〈http//www.cs.unc.edu/ azuma/ARpresence. pdf $>$. Acesso em out 2015.

BASTOS, N. C. Uma metodologia para avaliação de usabilidade de interfaces de realidade mista interativas. XXXV Conferência Latino -americana de Informática. 2007.

BOANANNI, L.; LEE, C. S. T. Attention-based design of augmented reality interfaces. 2005.

COSTABILI, M.; MARISCO, M. L. R. P. V. R. T. On the usability evaluation of elearning applications. Proceedings of the 38th Annual Hawaii International Conference on System Sciences. p. 3-6, 2005 .

FERNANDES, B.C.A.; SANCHES, J. F. Realidade aumentada aplicada ao design. Holos, Ano 24, Vol. 1, pp.28-47, 2008.

HAGUETTE, T. M; FHAGUETTE, T. M. F. Metodologias qualitativas na Sociologia. 5. ed. Petrópolis: Vozes, 1997.

HEISS, J. Coding from scratch: a conversation with virtual reality pioneer jaron lanier, part one. Sun.com: Technical Articles.2003. 
INSLEY, S. Obstacles to general purpose augmented reality. Acesso: http·//islab.oregonstate.edu/koc/ece399/f03/final/insley2.pdf. $2003 b$.

JEON, S; SHIM, H. K.G. J. Viewpoint usability for desktop augmented reality. The International Journal of Virtual Reality, Ano 5, Vol.3, pp.33-39, 2006. Disponível em <https//www.researchgate.net/publication/220222190_Viewpoint_Usability_for_Desktop_Augmented_ Reality>. Acesso em out. 2015.

KULAS, C. S. C.; KLINKER, G. M. T. U. S. L. F. A. Towards a development methodology for augmented reality user interfaces. The International Workshop exploring the Design and Engineering of Mixed Reality Systems.2004.

LAMB, P. Artoolkit documentation. Disponível em: <http·//artoolkit.sourceforge.net/apidoc/>. Acesso em: 10 out 2012. 2006.

LAUDON, K; LAUDON, J. Information systems. Prentice Hall. Marshall, D. (2001). What is multimedia? Disponível em: http·//www. cs.cf.ac.uk/Dave/Multimedia/node10.html.

MILGRAM, P.; KISHINO, F. A taxonomy of mixed reality viual display. IEICE Transaction of Information Systems, Vol. E77-D, n.12, 1994.

SCHOENFELDER, R.; SCHOENFELDER, D. Augmented reality for industrial building acceptance. In. Virtual Reality, IEEE: 83-90, 2008. 
VANDERDONCKT, J.; CHIEU, C. K. B. L. T. D. Model-based design, generation, and evaluation of virtual user interfaces. The ninth international conference on 3D Web technology (WEB3D'04), New York: ACM Press. p.51-61, 2004.

WANG, C.; REEVES, T. The meaning of culture in online education: implications for teaching, learning, and design. In. EDMUNDSON, A. Globalized E-Learning Cultural Challenges. Hershey, PA, USA: Information Science Publishing, p.1-17, 2007. 


\section{Maria Gracielly Lacerda de Abrantes \\ Robson Pequeno de Sousa}

\section{INTRODUÇÃO}

No cenário educacional, as tecnologias da informação e da comunicação assumem cada vez mais um papel ativo na configuração cognitiva do processo de ensino e aprendizagem, potencializando a construção de saberes significativos corroborando com as novas exigências de formação de indivíduos, profissionais e cidadãos na sociedade atual.

A escola contemporânea tornou-se alvo de reinvenção/ reestruturação do modelo pedagógico ao trabalhar com as tecnologias versáteis, as quais enfocam a Informática, Multimídia e Internet, deixando de ser tabuladas como transferências de informações para caracterizar-se como renovação constante.

Em pleno século XXI, a inclusão da tecnologia no ambiente educacional ainda sofre preconceito e promove instabilidade a muitos profissionais que não tiveram e não buscaram uma qualificação pro- 
fissional no âmbito das tecnologias da informação e comunicação, de modo a contemplar o ensino e a aprendizagem. Por sua vez, na ação do professor na sala de aula e na utilização que o mesmo faz dos suportes tecnológicos que se encontram à sua disposição, são novamente definidas "as relações entre o conhecimento a ser ensinado, o poder do professor e a forma de exploração das tecnologias disponíveis para garantir melhor aprendizagem pelos alunos” (KENSKI, 2007, p.19).

Diante do exposto, há a necessidade de formações continuadas que consolidem e complementem a qualificação dos professores, como forma de certificar o desenvolvimento de competências que o habilitem a refletir sobre as características dos nativos digitais, tomar consciência do papel da tecnologia na vida cotidiana, compreender a construção do conhecimento na sociedade da informação e descobrir como participar efetivamente desse processo e como inseri-lo em sua prática pedagógica, com o propósito de contribuir para a qualidade da educação e da inclusão social, atendendo às reais necessidades e interesses da nova geração.

Para tanto, surge o Programa Nacional de Informática na Educação, a implementação do mesmo deu-se em regime de estreita colaboração entre o MEC, os governos estaduais representados por suas respectivas Secretarias de Educação - SEE, objetivando a implantação de laboratórios de informática conectados à internet, promovendo formação continuada aos professores para o uso pedagógico das Tecnologias de Informação e Comunicação, ofertando conteúdos, recursos educacionais multimídia e digitais, soluções e sistemas de informação disponibilizados pelo MEC nos próprios computadores. Além disso, dispõem para professores e gestores cursos semipresenciais como: Introdução ao Educador Digital; Tecnologias na Educa- 
ção: Ensinando e Aprendendo com as TICs; Elaboração de Projetos e Redes de Aprendizagem.

O estudo alicerçou-se na contribuição social ao tratar das possibilidades propostas para o processo de ensino e aprendizagem apoiado pelo uso das tecnologias conectadas em redes, abordadas no curso de Redes de Aprendizagem pelo programa Proinfo Integrado. A motivação para este artigo partiu da vivência da pesquisadora quando cursista e formadora dos cursos do Proinfo Integrado, mas, sobretudo, a participação como aluna do curso de Especialização em Novas Tecnologias na Educação promovido pela Universidade Estadual da Paraíba. Ambos proporcionaram metodologias diferenciadas ao utilizarem recursos tecnológicos na prática pedagógica.

Os professores da rede pública, ao participarem das formações continuadas voltadas para o uso da tecnologia da informação e comunicação em sala de aula, sentem-se preparados para integrá-las na prática pedagógica, objetivando a aprendizagem da geração considerada como interativa?

O objetivo principal da pesquisa é investigar a apropriação de conhecimento em TIC por professores participantes da formação continuada pelo Proinfo no curso "Redes de Aprendizagem", no segundo semestre de 2014, promovido pelo Núcleo de Tecnologia Educacional na cidade de Patos-PB. Tendo-se como objetivos específicos: contextualizar a importância das TIC na educação e a formação de educadores para o uso das ferramentas digitais e sociais; compreender a proposta dos cursos ofertados pelo programa Proinfo Integrado para Educação Básica, como forma de propiciar uma formação sólida e abrangente aos educadores; e, por fim, realizar uma pesquisa de campo com um grupo de professores da rede Pública Estadual da cidade de Patos-PB, com a finalidade de investigar as contribuições provocadas a partir da forma- 
ção no curso de "Redes de Aprendizagem"sobre as possíveis transformações metodológicas acrescidas no processo de ensino e aprendizagem.

\section{EDUCAÇÃO NO SÉCULO XXI: NOVOS CENÁRIOS PEDAGÓGICOS}

Pensar na educação na sociedade da informação exige equacioná-la ao cenário globalizado de desenvolvimento tecnológico e as problemáticas das tecnologias de informação e comunicação nas instituições educacionais, as quais necessitam reconhecer o desafio democrático das possibilidades de acesso à informação e à comunicação por meios digitais, que se apresentam para os alunos.

As transformações sociais e inovações aceleradas das tecnologias promoveram mudanças comportamentais dos alunos. Segundo Veen e Vrakking (2009, p.29-30),

\footnotetext{
o uso das tecnologias influenciaram tanto o modo de pensar quanto o comportamento dos nativos digitais, o mesmo ainda afirma que essa geração busca a maior parte das informações em apenas um clique de distância, tendo uma visão positiva de onde obter as informações corretas no tempo certo, de qualquer pessoa e lugar.
}

Deste modo, a educação deve-se atentar para reformulações de novos paradigmas educacionais, de modo a entender e valorizar positivamente os impactos das tecnologias no âmbito pedagógico. Além disso, a comunidade escolar deve considerar a influência sobre as variáveis psicológicas dos alunos, os quais operam facilmente nos dispositivos tecnológicos.

A geração digital está moldando a educação, pois a mesma vive, comunica-se e aprende de um modo diferente, para o qual habi- 
lidades, atitudes e comportamentos novos tornam-se espontâneos. O novo panorama da sociedade da informação baseia-se nas necessidades de aprendizagem e teorias que descrevem os princípios e processos de aprendizagem, que reflitam sobre o ambiente social vigente.

A tecnologia influenciou na modernização da educação de maneiras diferentes em cada época. Papert (1993, p.19) cita as ideias de grandes teóricos da aprendizagem em seu livro "A Máquina das Crianças".

[...] a ideia de John Dewey de que as crianças aprenderiam melhor se a aprendizagem realmente fosse parte da experiência de vida; ou a ideia de Paulo Freire de que elas aprenderiam melhor se fossem realmente responsáveis por seus próprios processos de aprendizagem; ou a ideia de Jean Piaget de que a inteligência surge de um processo evolutivo no qual muitos fatores devem dispor de tempo para encontrar seu próprio equilíbrio; ou a ideia de $\mathrm{Vy}$ gotsky de que a conversação desempenha um papel crucial na aprendizagem.

Para Boyle (1997), o Construtivismo tem sido a abordagem teórica mais utilizada para orientar o desenvolvimento de materiais didáticos informatizados, principalmente o de ambientes multimídia de aprendizagem. Siemens (2004) vem acrescentar as abordagens teóricas do Behaviorismo e do Cognitivismo, e deixa claro que todas as abordagens são bem-vindas em prol do alcance dos objetivos de produzir conhecimento, seja ele no ambiente on-line ou presencial.

Estas concepções levantaram reflexões relacionadas aos conceitos sobre educação e às constantes inovações da sociedade conectada. O termo conexão será aqui entendido, conforme nos informa Filatro (2004, p.102), como momento em que muitos se encontram em torno de uma mesma ideia. 
A conectividade se dá quando duas ou mais pessoas se aproximam mentalmente, interagem conversam ou colaboram. Com o auxílio de telégrafos, rádios, telefones ou de redes digitais de comunicação, essas pessoas podem estar em lugares diferentes, distantes. O avanço e a ampliação do uso da Word Wide Web (WWW) transformaram as possibilidades de conectividade entre as pessoas.

Como visto, surge uma nova concepção de aprendizagem, que defende a ideia de conectivismo, o qual remete a significados da sociedade atual em sua formação para educação.

Conectivismo é a integração de princípios explorados pelo caos, rede, e teorias da complexidade e auto-organização. A aprendizagem é um processo que ocorre dentro de ambientes nebulosos onde os elementos centrais estão em mudança - não inteiramente sob o controle das pessoas. A aprendizagem (definida como conhecimento acionável) pode residir fora de nós mesmos (dentro de uma organização ou base de dados), é focada em conectar conjuntos de informações especializados, e as conexões que nos capacitam a aprender mais são mais importantes que nosso estado atual de conhecimento (SIEMENS, 2004).

O teórico idealizador da aprendizagem conectivista pontua que, na era digital, não é possível adquirirmos pessoalmente toda a quantidade de informação disponível sobre determinado assunto, pois continuamente surgem novas informações a serem absorvidas. Mediante este fluxo abundante de informações, a formação de conexões com demais pessoas e redes de relacionamentos tem-se revelado atividade essencial para a aprendizagem.

Assim, o ambiente escolar deve reestruturar os objetivos para o processo de ensino e aprendizagem, para isso, a formação continuada, como aperfeiçoamento profissional dos educadores sob o uso das ferramentas digitais e sociais disponíveis, é de suma importância para ativação de um processo educacional mais significativo. 
Com a interação das TIC no processo de ensino e aprendizagem, o educador deve aprender a dominar e a valorizar não só o novo instrumento ou o sistema de representação do conhecimento, mas de criar uma nova cultura de aprendizagem.

Há uma preocupação com a preparação de educadores e educandos para tornar o recurso digital eficiente. O Ministério da Educação (MEC) previne-se, enfatizando que

[...] o emprego deste ou daquele recurso tecnológico, de forma isolada e desalinhada com a proposta pedagógica da rede de ensino e da escola, não é garantia de melhoria da qualidade da educação. Somente por meio da conjunção de diversos fatores e a inserção da tecnologia no processo pedagógico da escola e do sistema é possível promover um processo de ensino-aprendizagem de qualidade (BRASIL, 2013, p.10).

Gadotti (2000, p.5) afirma que "á função da escola será, cada vez mais, a de ensinar a pensar criticamente. Para isso é preciso dominar mais metodologias e linguagens, inclusive a linguagem eletrônica”. Além disso, ensinar e aprender exige mais flexibilidade, espaçotemporal, pessoal e de grupo, menos conteúdos fixos e processos mais abertos de pesquisa e de comunicação.

A medida implantada pelo MEC concentra-se na formação continuada do docente, investimento esse que acredita na possibilidade de mudança, aperfeiçoamento profissional, troca de experiências e, sobretudo, busca e seleção de informações em diferentes fontes mediante o uso das novas tecnologias.

O conjunto de processos formativos para educação, contemplando a Tecnologia Educacional, lançado em 2008, com reedição e revisão em 2009, inseriu o curso de Redes de Aprendizagem, que contempla o contexto atual do uso das tecnologias na escola a par- 
tir da ampliação do acesso e da conectividade, da disponibilidade de novos dispositivos e da necessidade de maior ênfase na apropriação curricular das TIC, assim como da reflexão sobre o impacto das novas mídias sociais nas escolas.

\section{ASPECTO METODOLÓGICO}

A pesquisa apresentada refere-se a um estudo de caso, a partir da classificação de Ludke e André (1986, p. 13), como sendo uma pesquisa qualitativa que "envolve a obtenção de dados descritivos, obtidos no contato direto do pesquisador com a situação estudada, enfatiza mais o processo do que o produto e se preocupa em retratar a perspectiva dos participantes”.

A apresentação e análise dos dados foram realizadas por meio da estatística descritiva, isso para avaliação de variáveis do tipo qualitativa. Outras medidas estatísticas ainda foram utilizadas a fim de que fossem contemplados os dados de caráter quantitativos constantes nesta pesquisa.

A amostra deste estudo foi estabelecida a partir dos professores vinculados à Rede Pública de ensino, lotados na Secretaria de Educação do Estado da Paraíba, atuantes nas 6 ${ }^{\mathrm{a}}$, $7^{\mathrm{a}}$ e $11^{\mathrm{a}}$ Gerências Regionais de Ensino. Os mesmos participaram da formação continuada pelo Proinfo Integral no curso de Redes de Aprendizagem, ofertada no segundo semestre de 2014 e promovida pelo Núcleo de Tecnologia Educacional - Patos/PB.

Dos 20 professores que finalizaram o curso, apenas 16 contribuíram ao responderem o questionário para o estudo de caso. A pesquisa objetivou investigar a apropriação de conhecimento em TIC por professores participantes do curso de Redes de Aprendizagem 
promovido pelo Proinfo Integrado na cidade de Patos- $\mathrm{PB}$, realizado entre os meses de setembro a dezembro de 2014.

A análise dos dados coletados através de um questionário distribuído e compartilhado pelo google drive (formulário on-line) foi confrontado e corroborado com o referencial teórico exposto por autores como, Kenski (2007), Veen e Vrakking (2009), Siemens (2004), a respeito da sociedade da informação conectada em rede. Considerando o aumento dos investimentos tecnológicos na educação, bem como a formação continuada pela busca de inovação na prática pedagógica dos professores, visando à utilização adequada das ferramentas tecnológicas.

\section{RESULTADOS E DISCUSSÃO}

Os dados coletados forneceram algumas identificações dos professores participantes da pesquisa, e sua apropriação frente aos impactos das tecnologias da informação e da comunicação sob a ótica da formação dos educadores e da prática pedagógica destes, junto aos discentes, de modo a diagnosticar a situação dos professores sobre o uso das TIC na prática pedagógica.

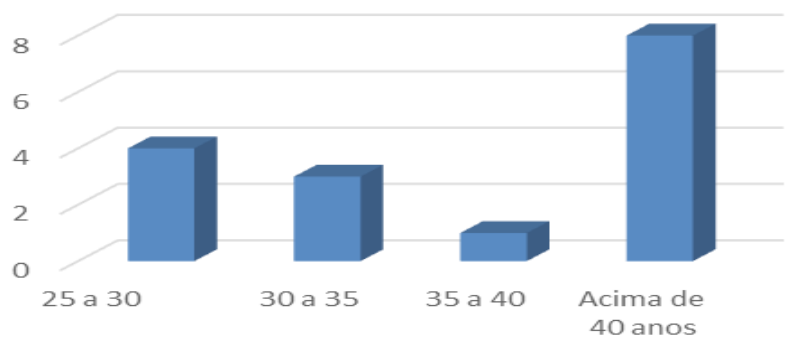

Figura 1: Faixa Etária

Fonte: Dados da pesquisa, 2015. 
$\mathrm{Na}$ Figura 1, percebe-se uma distribuição de frequência num intervalo de classe de 5 anos, a partir de 25 anos de idade. Observa-se, ainda, quanto ao perfil dos participantes da pesquisa, a predominância de professores acima de 40 anos, podendo elencar que as tecnologias da informação e comunicação, em sua fase de formação docente, não faziam parte na sua prática de ensino. Isso permite a inferência de que tais profissionais tinham a perspectiva, em sua formação inicial, da visibilidade de inovação da metodologia de ensino apoiada pelas ferramentas tecnológicas na prática pedagógica. Nesta perspectiva, apresenta-se um comparativo com estudos realizados por Costa (2012) e Serafim (2002), uma vez que ambos tiveram maior representatividade de professores com idade acima de 40 anos; percebe-se, com isso, que a grande maioria busca aprimorar seus conhecimentos ao participarem de formações continuadas em tecnologia educacional.

Quanto à experiência acadêmica envolvendo a titulação, observa-se, na Figura 2, que a maioria é formada por especialistas (56\% ) e graduados (38\%), sendo que o percentual de mestres (6\% ) e doutores $(0 \%)$ é, consideravelmente, baixo. Este fato pode ser justificado pela disponibilidade e oportunidades que os professores do ensino básico não tiveram para a continuidade acadêmica, o que pode impactar o próprio fazer pedagógico no ambiente educacional. 


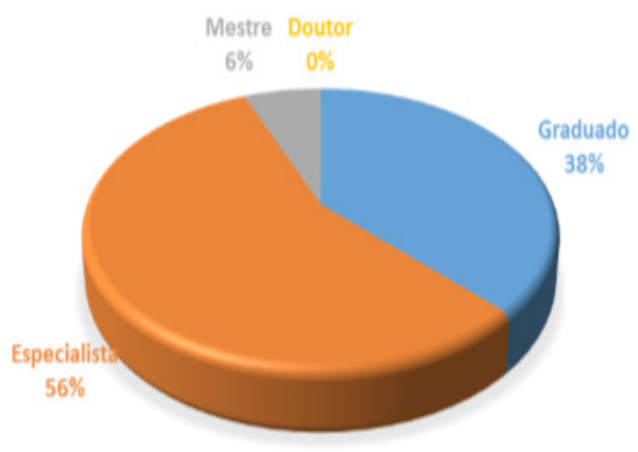

Figura 2: Grau de Formação Acadêmica

Fonte: Dados da pesquisa, 2015.

Segundo dados do Censo Escolar (BRASIL, 2013), o percentual de professores da Educação Básica com pós-graduação acentua-se apenas em 31,1\% dos docentes com esse tipo de formação. Nesse sentido, ressalvam-se as palavras de Cury (2004, p.778) que o "ser professor não resume em si apenas o docente capaz de ensino, mas inclui o pesquisador dotado de condições para promover a investigação e para absorver os resultados da pesquisa”. Pensar na formação progressiva é pôr em relevo a sua história e seus objetivos durante a trajetória acadêmica/profissional.

Com relação à área do conhecimento, a qual os respondentes atuam no ambiente escolar, nota-se, na Figura 3, que 50\% dos professores são da área de Códigos e Linguagens e suas Novas Tecnologias, sendo que 25\% são de Ciências da Natureza, 13\% Ciências Humanas e $12 \%$ na área de Matemática. Diante deste percentual, os professores, com mais necessidade em busca de formação continuada voltada para as tecnologias educacionais, foram os de códigos e linguagens com maior participação. 


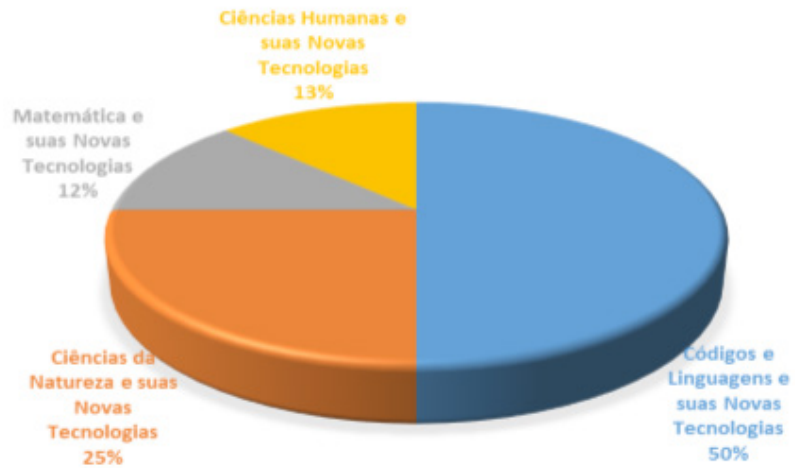

Figura 3: Área do conhecimento que os professores participantes atuam

Fonte: Dados da pesquisa, 2015.

A fim de que sejam alcançados resultados mais eficazes no que concerne ao enriquecimento didático e à promoção de interatividade das aulas, com ferramentas digitais off-line ou on-line, estabelece-se a relevância de se utilizar os laboratórios de informática. Isso pode, conseguintemente, promover a curiosidade de conhecer o funcionamento e as possibilidades de utilizar tais ferramentas para atividades posteriores. Deste modo, a Figura 4 ilustra a frequência de uso do laboratório de informática em prol da sua prática de ensino, sendo que $38 \%$ dos respondentes usam mais de duas vezes por semana com seus alunos, $31 \%$ uma ou duas vezes por mês e $31 \%$ mensalmente. 


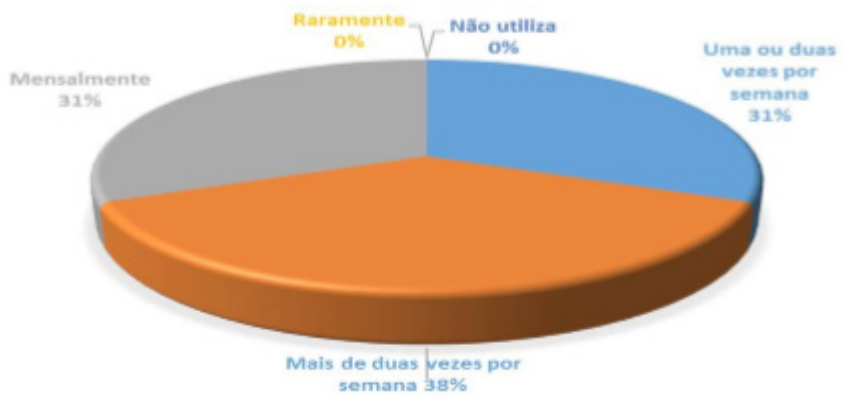

Figura 4: Frequência de utilização do laboratório de informática como recurso metodológico para auxiliar nas aulas

Fonte: Dados da pesquisa, 2015

As formações continuadas ofertadas pelo programa Proinfo Integrado proporcionam para os educadores meios para que possam compreender o potencial pedagógico de recursos das TIC, planejando estratégias de ensino e aprendizagem, integrando ferramentas tecnológicas.

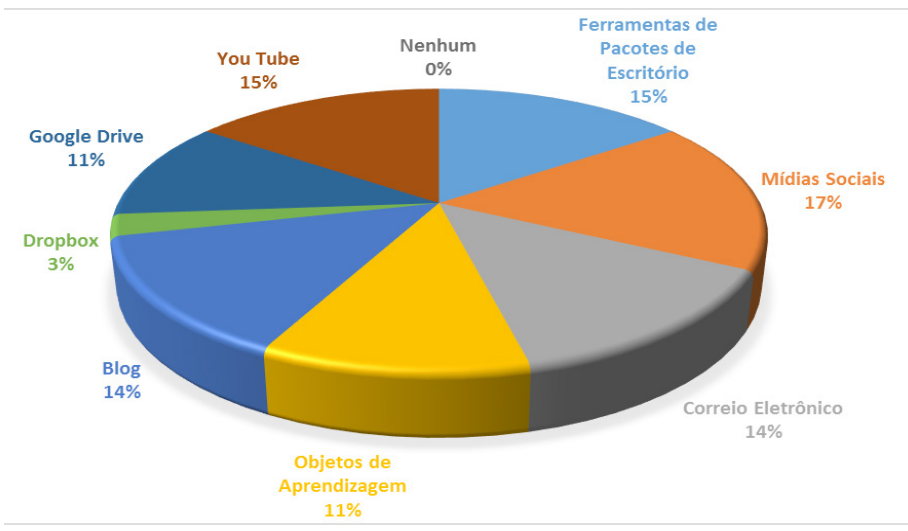

Figura 5: Ferramentas digitais e on-line que contribuem para prática pedagógica como promoção da aprendizagem dos alunos

Fonte: Dados da pesquisa, 2015. 
Então, verifica-se, na Figura 5, a contribuição de algumas ferramentas digitais e on-line utilizadas na prática de ensino destes professores, os quais criaram novas situações de aprendizagem levando os estudantes à construção de conhecimento, à criatividade, ao trabalho colaborativo. Como visto, $17 \%$ utilizam as mídias sociais como meio de interação e publicação, $15 \%$ operam em pacotes de escritórios, $15 \%$ fazem uso do You Tube, $14 \%$ usam a metodologia de blog para a produção e divulgação em rede, $14 \%$ investem no Correio eletrônico, $11 \%$ aplicam objetos de aprendizagem e utiliza o Google Drive como ferramenta colaborativa no processo de ensino e aprendizagem, sendo que apenas 3\% utilizam o Dropbox para o armazenamento em rede.

Os dados revelam que, após a formação, os ambientes virtuais foram integrados à prática pedagógica, como o uso do blog e do correio eletrônico às atividades com os alunos. Essa indicação parece revelar que os docentes acordaram para a necessidade de inserir na prática pedagógica ferramentas que ajudam a aproximar pessoas, a distribuir o conhecimento e a incentivar a aprendizagem colaborativa e que o blog pode ser utilizado como um laboratório de escrita virtual e os blogueiros podem agir, interagir e trocar experiências, difundir projetos desenvolvidos na escola, além de terem acesso a informações atualizadas (MOLIN, 2010).

Conforme a abordagem deste estudo, a análise qualitativa foi tabulada diante da análise interpretativa das questões abertas descritas pelos respondentes. No entanto, a complexidade de interpretação das mesmas tornou-se difícil pela heterogeneidade das respostas. Diante disso, os dados foram organizados em cinco quadros, estruturados por: indicadores (ênfase da pergunta), respostas (interpretação das respostas) e a frequência absoluta (quantidade de professores que 
responderam em consonância) e a frequência relativa (mensura a frequência absoluta em porcentagem).

Tabela 1 - Responsabilidade do Professor pela inovação metodológica em sala de aula

\begin{tabular}{|c|c|c|c|}
\hline Indicador & Respostas & $\mathbf{F}_{\mathrm{A}}$ & $F_{R}$ \\
\hline \multirow{5}{*}{$\begin{array}{l}\text { Evolução Tecno- } \\
\text { lógica e inovação } \\
\text { metodológica na } \\
\text { sala de aula. }\end{array}$} & $\begin{array}{l}\text { Responsabilidade do professor } \\
\text { em inovar as práticas de ensino e } \\
\text { acompanhar a evolução tecnológi- } \\
\text { ca atualizando-se. }\end{array}$ & 09 & $56,25 \%$ \\
\hline & $\begin{array}{l}\text { Melhorar a aprendizagem, tor- } \\
\text { nando-a significativa. }\end{array}$ & 02 & $12,5 \%$ \\
\hline & $\begin{array}{l}\text { Conscientização sobre a necessi- } \\
\text { dade da formação continuada }\end{array}$ & 03 & $18,75 \%$ \\
\hline & $\begin{array}{l}\text { Falta de laboratório de Informáti- } \\
\text { ca nas Escolas }\end{array}$ & 01 & $6,25 \%$ \\
\hline & $\begin{array}{l}\text { Falta de formação continuada } \\
\text { sobre o uso de recursos tecnoló- } \\
\text { gicos. }\end{array}$ & 01 & $6,25 \%$ \\
\hline Total & & 16 & 100 \\
\hline
\end{tabular}

Fonte: Dados da Pesquisa, 2015.

Pelas respostas obtidas e mostradas na tabela 1 , verificase que os professores são os principais responsáveis pela inovação da prática de ensino e que se faz necessário o corpo docente acompanhar a evolução tecnológica. Menezes (2009, p.31) "retrata que a reflexão sobre a prática pedagógica rompe com o que é convencional e pode realizar com a interveniência da tecnologia e do professor”.

Além disso, 12,5\% afirmam que a aplicação metodológica por meio de ferramentas tecnológicas melhora a aprendizagem dos discentes a ponto de torná-la significativa. Moran (2000) aponta que o indivíduo aprende pelo interesse, pela necessidade, quando vivencia, experimenta, sente, estabelece vínculos, descobre novas possibilidades e integra o sensorial, o racional, o emocional, o ético, o pessoal e 
o social. A utilização adequada e crítica das tecnologias recentes, na educação, propicia ambientes mais próximos da natureza interdisciplinar do processo de conhecimento e da interatividade dos processos cognitivos (SERAFIM, 2002).

Para tanto, 18,75\% dos respondentes levantaram, sobre a conscientização por parte dos professores atuantes em sala de aula, a necessidade e importância da formação continuada. Conforme Tornaghi (2007), a formação continuada reveste-se de singular oportunidade para a construção de um novo papel para o professor, que acresce a função de transformar criticamente a realidade escolar por meio da construção e da disseminação do conhecimento. Porém, 6,25\% alegaram a falta de laboratório de informática e de formação continuada voltada para o uso dos recursos tecnológicos.

A tabela 2 trata da contribuição dos cursos ofertados pelo Programa Nacional de Formação Continuada em Tecnologia Educacional na prática pedagógica do docente. De acordo com os achados desta pesquisa, 37,5\% dos respondentes afirmaram que foi bastante significativa a participação nas formações propostas pelo Proinfo Integrado, valorizando e incentivando a usabilidade dos recursos tecnológicos com o propósito de promover aulas mais atrativas e dinâmicas; dessa forma, $18,75 \%$ acreditam que esta metodologia pode facilitar a aprendizagem dos conteúdos abordados e a troca de conhecimento. Girardi (2011, p.20) considera que "é fundamental a formação e capacitação acerca das novas tecnologias educacionais, pois quando utilizadas de maneira inteligente, produzem intensa democratização de conhecimento e de produção”. 
Tabela 2 - Contribuições das formações continuadas pelo Proinfo Integrado para a prática pedagógica sob o uso de recursos tecnológicos

\begin{tabular}{|c|c|c|c|}
\hline Indicador & Respostas & FA & FR \\
\hline \multirow{4}{*}{$\begin{array}{l}\text { Formação Con- } \\
\text { tinuada pelo } \\
\text { Proinfo Integrado } \\
\text { e prática pedagó- } \\
\text { gica. }\end{array}$} & $\begin{array}{l}\text { Significativa a contribuição do } \\
\text { Programa Proinfo Integrado } \\
\text { no incentivo à usabilidade dos } \\
\text { recursos tecnológicos na práti- } \\
\text { ca pedagógica. }\end{array}$ & 06 & $37,5 \%$ \\
\hline & $\begin{array}{l}\text { Incentivo à promoção de aulas } \\
\text { mais atrativas e dinâmicas } \\
\text { facilitando a aprendizagem } \\
\text { dos conteúdos e a troca de } \\
\text { conhecimento. }\end{array}$ & 04 & $25 \%$ \\
\hline & $\begin{array}{l}\text { O professor deve ser um cons- } \\
\text { tante pesquisador em busca de } \\
\text { novos métodos. }\end{array}$ & 04 & $25 \%$ \\
\hline & $\begin{array}{l}\text { Resistência e medo em utilizar } \\
\text { as tecnologias em sala de aula. }\end{array}$ & 02 & $12,50 \%$ \\
\hline Total & & 16 & 100 \\
\hline
\end{tabular}

Fonte: Dados da Pesquisa, 2015.

Os professores reconhecem a necessidade de usar os computadores, porém a maioria ainda com um olhar de usuário, e não como ferramenta eficaz para mediar o trabalho pedagógico. "Esse fato sinaliza que esses docentes ainda não despertaram para as possibilidades que as tecnologias trazem para a prática pedagógica e para o processo de aprendizagem dos alunos" (MOLIN, 2010, p.254).

Percebe-se que há a vontade dos professores de se aproximarem das tecnologias recentes, mas, ao mesmo tempo, resistem à utilização das mesmas por não sentirem segurança no seu valor de agregação pedagógica para ensinar e aprender. Neste sentido, Moran (2000, p.16) afirma que "as mudanças na educação dependem, em pri- 
meiro lugar, de termos educadores maduros intelectual e emocionalmente, pessoas curiosas, entusiasmadas, abertas, que saibam motivar e dialogar [...]”. Isso se justifica porque

[...] a implantação de novas ideias depende, fundamentalmente, das ações do professor e dos alunos. Porém, essas ações, para serem efetivas, devem ser acompanhadas de uma maior autonomia para tomar decisões, alterar o currículo, desenvolver propostas de trabalho em equipe e usar novas tecnologias da informação [...] (VALENTE, 1999, p.41).

Nesta perspectiva, pensar na utilização das tecnologias na educação implica a reflexividade das ações docentes, as quais devem buscar mudanças como tomada de consciência. Contudo, vale salientar que mudar não é fácil, pois envolve decisão, coragem e, sobretudo, ousadia. Consiste, portanto, ter medo de projetar novas metodologias de ensino apoiadas pelas TIC.

Os dados revelados, na tabela 3, esboçam a interação entre aluno e professor, aluno e aluno, aluno e conteúdo ao utilizarem as ferramentas digitais e sociais no processo de ensino e aprendizagem. Observa-se que 31,25\% dos professores asseguraram que há maior interesse e participação nas aulas pelos alunos, além da interação entre todos os colaboradores da aprendizagem (professor, colegas e conteúdo). Ao utilizar os recursos tecnológicos para o processo de ensino e aprendizagem, espera-se que o aluno ganhe autonomia e que possa gerenciar os próprios passos na construção do conhecimento. Para Silva (2000), a interatividade é um elemento significativo nesta busca de autonomia e de focalização da educação para o aluno, pois permite que este ultrapasse a condição de espectador passivo para a condição de sujeito operativo. 
Deste modo, percebe-se que 12,5\% dos respondentes acreditam na descoberta de novos caminhos na busca de informação, oportunizando o educando a tornar-se autor e compartilhar seu conhecimento. Piaget (1973, p.34) define as interações como sendo ações se modificando umas com as outras, conforme determinadas leis de organização ou equilíbrio. Conforme Piaget (1973 apud BEHAR; MORESCO, 2009, p.267), além dos fatores orgânicos, que condicionam do interior os mecanismos da ação, toda conduta supõe duas espécies de interação que se modificam de fora e são indissociáveis uma da outra. Há, portanto, a interação entre o sujeito e os objetos e a interação entre sujeito e outros sujeitos. 
Tabela 3 - Interação provocada pela utilização das ferramentas digitais e sociais na prática pedagógica

\begin{tabular}{|c|c|c|c|}
\hline Indicador & Respostas & FA & FR \\
\hline \multirow{8}{*}{$\begin{array}{l}\text { Interação, ferra- } \\
\text { mentas digitais e } \\
\text { sociais na prática } \\
\text { pedagógica. }\end{array}$} & $\begin{array}{l}\text { Maior interesse, participação e } \\
\text { interação dos alunos com o pro- } \\
\text { fessor, colegas e o conteúdo. }\end{array}$ & 05 & $31,25 \%$ \\
\hline & $\begin{array}{l}\text { Familiaridade dos alunos com } \\
\text { recursos tecnológicos. }\end{array}$ & 02 & $12,5 \%$ \\
\hline & $\begin{array}{l}\text { Possibilita a inovação da prática } \\
\text { de ensino. }\end{array}$ & 03 & $18,75 \%$ \\
\hline & $\begin{array}{l}\text { Descoberta de novos caminhos } \\
\text { na busca de informação oportu- } \\
\text { nizando o educando tornar-se } \\
\text { autor e compartilhar seu conhe- } \\
\text { cimento. }\end{array}$ & 02 & $12,5 \%$ \\
\hline & $\begin{array}{l}\text { Possibilidade da interação aluno } \\
\text { e professor fora do ambiente } \\
\text { escolar através das mídias sociais. }\end{array}$ & 01 & $6,25 \%$ \\
\hline & $\begin{array}{l}\text { Planejamento e estabelecimento } \\
\text { de objetivos em relação à utiliza- } \\
\text { ção das ferramentas tecnológicas } \\
\text { em sala de aula. }\end{array}$ & 01 & $6,25 \%$ \\
\hline & $\begin{array}{l}\text { Falta de acesso a recursos tecno- } \\
\text { lógicos fora da escola. }\end{array}$ & 01 & $6,25 \%$ \\
\hline & $\begin{array}{l}\text { Os recursos muitas vezes não são } \\
\text { usados para fins pedagógicos. }\end{array}$ & 01 & $6,25 \%$ \\
\hline Total & & 16 & 100 \\
\hline
\end{tabular}

Fonte: Dados da Pesquisa, 2015.

Diante da perspectiva de se trazer um norte mais objetivo ao que se propõe, considera-se que os alunos têm o domínio de utilizar os recursos tecnológicos facilmente; em contrapartida, os professores não têm essa presteza na usabilidade, mas são os responsáveis por mediar e estabelecer estratégias de ensino que possibilitem a 
inovação da prática pedagógica por meio das mídias digitais e sociais. Veen e Vrakking (2009, p.35) enfatizam que "o Homo Zappiens lida com extrema facilidade com os computadores e sem necessidade de fazer cursos”. Porém, muitos não dispõem de condições financeiras para posse de certos recursos tecnológicos, e um dos fatores que implicam na aplicação das mídias fora do ambiente escolar é o acesso para realizar atividades síncronas ou assíncronas. Outro fator que preocupa 6,25\% destes professores é a forma de como estão utilizando os recursos tecnológicos, ou seja, os alunos não aproveitam para fins educacionais.

Freire (1996, p.46) assegura que: "ensinar exige compreender que a educação é uma forma de intervenção do mundo". Deste modo, percebe-se, na tabela 4 , um reforço da percepção dos respondentes com relação aos benefícios promovidos ao utilizarem correto e pedagogicamente as tecnologias para ensinar e aprender. Com $43,75 \%$ de unanimidade, responderam que os resultados são positivos ao trabalharem com as tecnologias, $31,25 \%$ afirmaram que as aulas tornam-se mais atrativa e produtivas e $25 \%$ admitem que facilitam a assimilação do conteúdo. Libânio (2000, p.58) diz que 'fazer uma leitura pedagógica dos meios de comunicação é verificar a intencionalidade dos processos comunicativos (de natureza política, ética, psicológica e didática) presentes nas novas tecnologias de comunicação e da informação e nas formas de intervenção metodológica e organizativa."É preciso enfatizar o uso das tecnologias da informação e comunicação como fonte inovadora do processo de aprendizagem, visando a um melhor aproveitamento e rendimento das atividades desenvolvidas neste setor. 
Tabela 4 - Resultados da aprendizagem comparado ao método de ensino

\begin{tabular}{|c|c|c|c|}
\hline Indicador & Respostas & FA & FR \\
\hline \multirow{3}{*}{$\begin{array}{l}\text { Aprendizagem e méto- } \\
\text { dos de ensino. }\end{array}$} & $\begin{array}{c}\text { Tornar as aulas atrativas e pro- } \\
\text { dutivas. }\end{array}$ & 05 & $31,25 \%$ \\
\hline & $\begin{array}{c}\text { Facilitar a assimilação dos } \\
\text { conteúdos trabalhados em sala } \\
\text { de aula. }\end{array}$ & 04 & $25 \%$ \\
\hline & $\begin{array}{l}\text { O uso da tecnologia traz resul- } \\
\text { tados positivos na aprendiza- } \\
\text { gem do aluno. }\end{array}$ & 07 & $43,75 \%$ \\
\hline Total & & 16 & 100 \\
\hline
\end{tabular}

Fonte: Dados da Pesquisa, 2015.

Veen e Vrakking (2009) ressaltam em seus estudos o Homo Zappiens, este termo caracteriza um novo tipo de geração, a qual pode ser considerada como nativos digitais. Explicam ainda que

essa geração cresceu usando múltiplos recursos tecnológicos desde a infância [...], esses recursos permitiram as crianças de hoje a ter o controle sobre o fluxo de informações, lidar com informações descontinuadas e com uma sobrecarga de informações, mesclar comunidades virtuais e reais, comunicarem-se e colaborarem em rede, de acordo com suas necessidades. (VEEN; VRAKKING, 2009, p.12).

Para tanto, fez-se necessário levantar a respectiva hipótese: O professor em sua prática pedagógica de ensino corrobora para aprendizagem destes nativos digitais através das mídias digitais? Com exceção de apenas um professor não ter respondido a respectiva pergunta, constata-se que 53,33\% dos respondentes informaram que utilizam as mídias digitais, redes sociais e entre outros aparatos tecnológicos para fortalecer a aprendizagem dos discentes. 33,34\% responderam que sua prática de ensino ainda é passiva ao utilizar estes 
recursos, apesar de tantas possibilidades serem proporcionadas por diversas ferramentas tecnológicas.

Verifica-se também, na tabela 5, que 13,33\% dos respondentes ainda se sentem inseguros ao aplicar as tecnologias digitais em sua prática de ensino direcionada para os nativos digitais. Quanto a isso, Kenski (2003) destaca que o professor precisa se sentir confortável para utilizar os novos auxiliares didáticos. Ou seja, ele precisa conhecer as propriedades de cada recurso tecnológico, dominar os procedimentos técnicos, avaliá-los criticamente e criar novas possibilidades pedagógicas, partindo da interação desses meios com o processo de ensino.

Tabela 5 - Colaboração para aprendizagem dos nativos digitais, tendo como estratégia de ensino o uso das mídias digitais

\begin{tabular}{|c|c|c|c|}
\hline Indicador & Respostas & FA & FR \\
\hline \multirow{3}{*}{$\begin{array}{l}\text { Estratégia de ensino } \\
\text { apoiada com as TIC } \\
\text { no processo de apren- } \\
\text { dizagem. }\end{array}$} & $\begin{array}{l}\text { A prática de ensino usada } \\
\text { com os nativos digitais ainda } \\
\text { é passiva diante das inúme- } \\
\text { ras possibilidades existentes } \\
\text { com as mídias digitais e } \\
\text { sociais. }\end{array}$ & 05 & $33,34 \%$ \\
\hline & $\begin{array}{l}\text { Fortalecimento da aprendi- } \\
\text { zagem com o uso das mídias } \\
\text { digitais, redes sociais e } \\
\text { outros aparatos tecnológicos }\end{array}$ & 08 & $53,33 \%$ \\
\hline & $\begin{array}{l}\text { Insegurança dos professores } \\
\text { em relação ao uso das tec- } \\
\text { nologias a serem utilizadas } \\
\text { pedagogicamente com os } \\
\text { nativos digitais. }\end{array}$ & 02 & $13,33 \%$ \\
\hline Total & & 15 & 100 \\
\hline
\end{tabular}

Fonte: Dados da pesquisa, 2015. 
As análises dessas respostas revelam indícios interessantes quanto à contribuição da formação continuada em tecnologia educacional. Primeiramente, colaboraram para uma maior utilização das tecnologias da informação e comunicação, visto que as ferramentas digitais e sociais foram empregadas para fins educacionais. Em segundo lugar, contribuíram para que os professores cursistas ampliassem o domínio técnico e pedagógico do computador e das possíveis ferramentas tecnológicas, superando alguns anseios e expectativas. Portanto, sobre o resultado da participação dos professores no curso, considera-se que este contribuiu para mudar a prática pedagógica.

\section{CONSIDERAÇÕES FINAIS}

O trabalho mostrou a mobilização de políticas públicas governamentais em proporcionar formação continuada em tecnologia educacional, estratégias de responsabilidade do Programa Proinfo Integrado juntamente com os Núcleos de Tecnologias Educacionais. Realizamos o presente estudo de caso com a finalidade de investigar a apropriação de conhecimento dos professores participantes do curso "Redes de Aprendizagem".

Como um indicativo de resposta do estudo, apontam-se aspectos positivos em relação às experiências vivenciadas durante a formação dos professores. Destaca-se a ampliação de conhecimentos sobre tecnologia, o desenvolvimento da habilidade técnica e pedagógica para usar as ferramentas mais sofisticadas do computador e a utilização de ambientes informatizados no processo pedagógico, embora os dados tenham sinalizado que ainda sejam poucos os docentes que incluem os recursos digitais nas atividades diárias com os alunos. A esse respeito, os dados também mostraram que existem problemas 
que limitam o acesso dos alunos aos recursos tecnológicos fora do ambiente escolar.

Outro aspecto visível na interpretação dos dados foi a falta de conscientização dos professores no seu próprio processo de aprendizagem, fazendo valer-se que a formação continuada é um caminho percorrido por aqueles que sentem necessidade de desenvolvimento profissional, que possa ajudá-los a terem consciência das dificuldades, ressignificá-las e construírem soluções.

Professores participativos e inovadores no modelo de educação privilegiam as necessidades atuais e acompanham os avanços tecnológicos, sentem-se mais seguros em utilizar as tecnologias da informação e comunicação em benefício do processo de ensino e aprendizagem, não se importando apenas com as quatro paredes de uma sala de aula, de modo a possibilitar para o aluno um mundo ao seu redor dentro e fora desse ambiente.

Essas novas ferramentas tecnológicas estudadas, como as mídias digitais e sociais, produzem efeitos de comunicação muito superiores aos antigos métodos e proporcionam ao professor um conhecimento melhor do aluno no que se refere à sua forma de comunicar e compreender o mundo em que vive.

De acordo com os dados relacionados à prática e aos conhecimentos específicos adquiridos, a ratificação desses ocorreu parcialmente satisfatória, considerando as ferramentas tecnológicas, as quais são utilizadas em sua prática de ensino. Diante do exposto, observa-se um valor de importância ao usar as tecnologias digitais e sociais na prática pedagógica, permitindo concluir que esta conscientização é o primeiro indicador para corroborar com a mudança no contexto escolar, colaborando positivamente com o processo de aprendizagem dos nativos digitais. 


\section{REFERÊNCIAS}

BEHAR. P. A. (orgs.). Modelos pedagógicos em educação a distância. Porto Alegre: Artmed, 2009.

BRASIL. Introdução à Educação Digital / Edla Maria Faust Ramos, Monica Carapeços Arriada, Leda Maria Rangearo Fiorentini. - 1. ed. Brasília: Ministério da Educação, Secretaria de Educação Básica, 2013. ISBN 978-85-296-0109-0.

BRASIL. Censo Escolar. Observatório do PNE. 2013. Disponível em www.observatoriopne.org.br . Acessado em 19 de junho de 2015.

BOYLE, T. Design for Multimedia Learning. London: Prentice Hall. 1997.

COSTA. A. T. Aprendizagem docente: o ciclo de apropriação do conhecimento na formação continuada mediada pelas tecnologias digitais. Campina Grande: UEPB, 2012.

CURY, C. R. J. Graduação/pós-graduação a busca de uma relação virtuosa. Educ. Soc. Campinas, vol. 25, n.88, Especial - Outubro 2004. Disponível em http://www.scielo.br/pdf/\% 0D;es/v25n88/a07v2588. pdf. Acessado em 23 de julho de 2015.

FILATRO, A. Design instrucional contextualizado: educação e tecnologia. São Paulo: Editora SENAC, São Paulo, 2004. 
FREIRE, P. Pedagogia da autonomia. Saberes necessários à prática educativa. São Paulo: Paz e Terra. 1996.

LIBÂNIO, J. C. Adeus professor, adeus professora?. 4 ed. São Paulo: Cortez, 2000.

GADOTTI, M. Perspectivas atuais da educação. In: São Paulo em perspectivas. N 14 (2). 2000. Disponível em < http://www.scielo.br/ pdf/spp/v14n2/9782.pdf $>$. Acesso em 16 de maio de 2015.

GIRARDI, S. C. A formação de professores acerca de novas tecnologias na educação. Universidade Estadual de Goiás: Brasília. 2011.

LÜDKE, M; ANDRÉ, M. E. D. A. Pesquisa em educação: abordagens qualitativas, São Paulo. EPU, 1986.

KENSKI, V. M. Educação e Tecnologias: O novo ritmo da informação. Campinas, São Paulo, Papirus, 2007.

Tecnologias do Ensino Presencial e a Distância. Campinas, SP Papirus, 2003.

MENEZES, C. S; VALENTE, J. A; BUSTAMANTE, S. B. V. Educação a distância: prática do profissional reflexivo. São Paulo: Avercamp, 2009.

MOLIN, S. I. L. Blogs: um espaço de criação coletiva na escola. Diário Catarinense, Florianópolis, 30 set. 2010. Escola Aberta, p.3. 
MORAN, J. M. Novas Tecnologias e mediação pedagógica - Campinas, SP: Papirus, 2000.

PAPERT, S. A Máquina das Crianças - Repensando a Educação na era da Informática. Porto Alegre: Artmed, 1993.

PIAGET, J. Aprendizagem e conhecimento. Rio de Janeiro: Freitas Bastos, 1973.

SSERAFIM, M. L. O vídeo digital como recurso multimídia integrado ao contexto escolar. In. Encontro de Pesquisa Educacional do Norte e Nordeste, 19, João Pessoa, 2009.

SILVA, M. Sala de aula interativa. Rio de Janeiro: Quartet, 2000.

SIEMENS, G. Connectivism: A Learning Theory for the Digital Age. 2004. Disponível em: http://www.elearnspace.org/Articles/connectivism.htm>. Acesso em: 28 junho de 2015.

TORNAGHI, A. J. C. Escola faz tecnologia, tecnologia faz escola. 166f. Tese (Doutorado em Engenharia de Sistemas e Computação) Universidade Federal do Rio de Janeiro, Rio de Janeiro, 2007.

VALENTE, J. A. (Org). O computador na sociedade do conhecimento. Campinas. São Paulo: UNICAMP/NIED, 1999.

VEEN, W.; VRAKKING, B. Homo Zappiens: educando na era digital. Trad. de Vinícius Figueira. Porto Alegre: Artmed, 2009. 


\section{SOBRE OS ORGANIZADORES}

\section{CAROLINA CAVALCANTI BEZERRA carol.cavalcanti.bezerra@gmail.com}

Possui Graduação em Comunicação Social com Bacharelado em Relações Públicas pela Pontifícia Universidade Católica de Campinas (1997). Mestra em Educação na área de concentração "Educação, Conhecimento, Linguagem e Arte"pela Faculdade de Educação da Universidade Estadual de Campinas (UNICAMP/2008) e Especialista em Novas Tecnologias na Educação pela Universidade Estadual da Paraíba (UEPB/2010). Foi bolsista do CNPq e pela Faculdade de Educação da UNICAMP colaborou como monitora do Programa de Capacitação para Diretores das Redes de Ensino Municipal e Estadual do Estado de São Paulo (GESTORES) e do Programa Especial para Formação de Professores em Exercício da Região Metropolitana de Campinas (PROESF). Fez parte, durante os anos de 2005 a 2008, como Pesquisadora, do Grupo de Pesquisa Laboratório de Estudos Audiovisuais - OLHO - da FE/UNICAMP. Tem experiência na área de Educação, com ênfase no uso do audiovisual como ferramenta de ensino; Educação a Distância e suas múltiplas linguagens, tutoria e capacitação de professores para a modalidade. Atualmente, trabalha junto ao Polo de Educação a Distância da Universidade Estadual da Paraíba como Coordenadora Pedagógica e de Tutores do curso de Licenciatura em Geografia a Distância e como Assessora da Pró-Reitoria de Ensino 
Médio, Técnico e Educação a Distância (PROEAD/UEPB). É pesquisadora do Grupo de Pesquisa (CNPq) 'Psicologia, Desenvolvimento e Educação' da UEPB.

\section{ELIANE DE MOURA SILVA elianemoura51@gmail.com}

Possui Graduação em Letras, Especialização em Literatura Brasileira pela Universidade Estadual da Paraíba (UEPB), Mestrado em Gestão Educacional pela Universidade Internacional de Lisboa (2002) e Doutorado em Ensino, História e Filosofia das Ciências (UFBA/UEPB). Pró-Reitora de Ensino Médio, Técnico e Educação a Distância, Professora do Departamento de Educação da UEPB, Coordenadora do Programa de Pós-Graduação Lato-Sensu - Educação Básica - em Municípios da Paraíba pela Universidade Estadual da Paraíba (UEPB). Atualmente, trabalha como Assessora da Pró-Reitoria de Ensino Médio, Técnico e Educação a Distância (PROEAD/UEPB).

\section{FILOMEMA MARIA GONÇALVES DA SILVA MOITA filomena_moita@hotmail.com}

Pedagoga, especialista em Desenvolvimento Infantil e seus Desvios, Mestra em Educação e Doutora em Educação na área de concentração em Educação, Comunicação e Cultura pela Universidade Federal da Paraiba, bolsista CAPES fez Doutorado sandwich na Universidade de Lisboa. Faz parte do corpo permanente dos Programas de Pós-graduação Mestrado em Ensino de Ciências e Educação Matemática e Mestrado Profissional em Formação de Professores da Educação Básica da Universidade Estadual da Paraíba - UEPB. Com 
publicações em periódicos especializados, trabalhos em anais de eventos nacionais e internacionais, capítulos de livros e livros publicados. Possui três softwares educativos sobre games no ensino. Orientadora de trabalhos de iniciação científica, trabalhos de conclusão de curso, de especialização, mestrado e coorientação de Doutorado com ênfase nas áreas de tecnologia e aquisição do conhecimento, tecnologia e ensino de ciências e matemática, TIC e formação de professores, letramento digital, didática e metodologia das ciências. Além de temas como Educação a Distância, Avaliação de Sistemas, Instituições, Planos e Programas Educacionais. Participou da produção de projetos em EAD para o edital da UAB assim como de produção de material didático e parecer para a EAD. Em suas atividades profissionais, interagiu com 43 colaboradores em coautorias de trabalhos científicos. Coordenadora do Grupo de Pesquisa - Tecnologias Digitais e Aquisição do Conhecimento (TDAC) (cadastrado no CNPq desde 2002) é pesquisadora da ANPEd desde 1997 é sócia da Sociedade Brasileira de Educação Matemática - SBEM, membro da Rede Brasileira de Jogos eletrônicos e da Comunidade Científica Portuguesa de Videojogos. Líder e pesquisadora de grupos de pesquisa cadastrados no CNPq.

\section{ROBSON PEQUENO DE SOUSA robson.pequeno@gmail.com}

Possui Doutorado em Engenharia Elétrica pela Universidade Federal da Paraíba (2000), Mestrado em Engenharia Elétrica pela Universidade Federal de Pernambuco (1991) e Graduação em Bacharelado em Matemática pela Universidade Federal da Paraíba (1985). Atualmente, é professor Doutor D da Universidade Estadual da Paraíba e Coordenador da Especialização Novas Tecnologias na 
Educação e vem realizando pesquisas na área de Tecnologia Educacional, member - Institute Of Electrical And Electronics Engineers, Inc. Tem experiência na área de Ciência da Computação, com ênfase em Teleinformática, atuando principalmente nos seguintes temas: rede neural modular morfológica, processamento de imagens, algoritmo genético, projeto de operadores morfológicos e reconhecimento de padrões. Foi coordenador da equipe da Universidade Católica de Pernambuco no projeto Transcodificação de Vídeo para o Sistema Brasileiro de TV Digital durante o período de agosto de 2005 a fevereiro de 2006. O projeto foi financiado com recursos da Financiadora Nacional de Estudos e Projetos (FINEP) e do Funtel. Atualmente tem atuado na área de tecnologias digitais na educação bem como no desenvolvimento de inovações tecnológicas em saúde. 


\section{Sobre o livro}

Projeto Gráfico e Editoração Lediana Costa

Design da Capa Erick Ferreira Cabral

Revisão Linguística Elizete Amaral de Medeiros

Normalização Jane Pompilo dos Santos

Impressão Gráfica Universitária da UEPB

Formato $15 \times 21 \mathrm{~cm}$

Mancha Gráfica 10 x 16,5 cm

Tipologias utilizadas Neuton Light 11/16 pt

Caudex Bold 12/ $18 \mathrm{pt}$

Papel Apergaminhado $75 \mathrm{~g} / \mathrm{m} 2$ (miolo) e Cartão Supremo 250g/m2 (capa) 